\title{
Poster
}

\section{Adipositas im Kinder- und Jugendalter}

\section{P01}

DER ZUSAMMENHANG VON SCHLAFDAUER UND BODYMASS-INDEX BEI 10- BIS 14-JÄHRIGEN UND SEINE BEDEUTUNG FÜR DIE ADIPOSITASPRÄVENTION

Wendt, E.-M. ${ }^{1}$; Pernerstorfer, E. ${ }^{1}$; Möseneder, J. ${ }^{1}$; Karner, G. ${ }^{1}$

${ }^{1}$ Fachhochschule St. Pölten GmbH, St. Pölten, Österreich

Fragestellung: Unter den 6-14jährigen ÖsterreicherInnen sind etwa ein Fünftel der Jungen und mehr als ein Sechstel der Mädchen übergewichtig oder adipös (ÖGK, 2007, S. 7). Eine Kombination von genetischer Determination, sozialen Faktoren und Lebensstilfaktoren trägt zur Entstehung von Übergewicht und Adipositas bei (Warschburger \& Petermann, 2008, S. 11ff). Neuere Studien deuten darauf hin, dass auch eine zu kurze Schlafdauer ein Risikofaktor für die Entstehung von Übergewicht und Adipositas bei Kindern und Jugendlichen ist. Schlafmangel verringert nicht nur die Bereitschaft für körperliche Aktivität, sondern erhöht auch durch hormonelle Mechanismen die Energiezufuhr (Patel \& $\mathrm{Hu}, 2008)$.

Ziel dieser Bachelorarbeit ist es, den Zusammenhang zwischen Schlafdauer und BMI bei Kindern/Jugendlichen zu untersuchen.

Methodik: In einer quantitativen, nicht invasiven Querschnittsstudie $(\mathrm{n}=301)$ wurde untersucht, ob bei 10-14jährigen in ÖsterreicherInnen ein Zusammenhang zwischen Schlafdauer und Body-Mass-Index (BMI) besteht und welche Faktoren dabei zusätzlich eine Rolle spielen könnten. In einem Selbstausfüller-Fragebogen (15 Items) wurden anthropometrische und sozio-demografische Daten sowie Schlafgewohnheiten erhoben.

Ergebnisse: Es fand sich eine signifikante Korrelation zwischen Schlafdauer und Body-Mass-Index. Weiters korrelierte der BMI signifikant mit dem Geburtsland, dem Nickerchen am Nachmittag und der Zeit des Schlafengehens am Abend. Im Vergleich von weiblichen und männlichen TeilnehmerInnen zeigte sich, dass Jungen bei zu kurzer Schlafdauer ein signifikant erhöhtes Risiko für Übergewicht bzw. Adipositas haben im Gegensatz zu jenen, die ausreichend schlafen $(\mathrm{OR}=6,1$; $\mathrm{p}=0,033$ ), unabhängig von Geburtsland und Schultyp. Für Mädchen ergab sich diese Korrelation nicht.

Schlussfolgerung: Einheitliche Vorgaben für die Schlafdauer von Kindern/Jugendlichen existieren nicht. Eine Empfehlung für eine ausreichende Nachtruhe ist kein Therapieansatz für Adipositas, wohl aber eine kostengünstige $\mathrm{Ma}$ ßnahme in der Prävention. Integriert in bestehende Präventionsprogramme kann sie dazu beitragen, die Entstehung von Übergewicht und Adipositas zu verringern. Aufgrund der Ergebnisse der vorliegenden Untersuchung wäre es denkbar, den Fokus auf Jungen und männliche Jugendliche zu legen. Die Stichprobe war klein und zudem nicht repräsentativ, daher sind weiterführende Untersuchungen an einer größeren Gruppe erforderlich, um die gewonnenen Erkenntnisse zu festigen und zu erweitern.

\section{P02}

\section{BODY-MASS-INDEX, WAIST-TO-HEIGHT RATIO AND WAIST CIRCUMFERENCE: PUBERTAL CHANGES AND ASSOCIATION WITH FASTING INSULIN, HOMA-IR, BLOOD PRESSURE AND OTHER MARKERS OF METABOLIC AND CARDIOVASCULAR RISK IN OBESE CHILDREN AGED 11-18 YEARS}

Blüher, S. $^{1}$; Molz, E. ${ }^{2}$; Wiegand, S. ${ }^{3}$; Bielstein, A. ${ }^{4}$; Sergeyev, E. ${ }^{5}$; Kiess, W. ${ }^{5}$; Tuschy, S. ${ }^{6}$; L'allemand-Jander, D. ${ }^{7}$; Holl, R. $^{2}$

${ }^{1}$ Integrated Research and Treatment Center (Ifb) Adiposity Diseases, University of Leipzig, Leipzig, Germany; ${ }^{2}$ Dept. of Epidemiology and Medical Biometry, University of Ulm, Ulm, Germany; ${ }^{3}$ Dept. of Pediatric Endocrinology and Diabetology, Charité Universitätsmedizin Berlin, Berlin, Germany; ${ }^{4}$ Children's Hospital Wilhelmsstift, Hamburg, Germany; ${ }^{5}$ Dept. of Women and Child Health, Hospital for Children and Adolescents, University Hospital of Leipzig, Leipzig, Germany; ${ }^{6}$ Sana Hospital Lichtenberg, Berlin, Germany; ${ }^{7}$ Dept. of Pediatric Endocrinology and Diabetology, Children's Hospital St. Gallen, St. Gallen, Switzerland

Objective: Besides BMI to define the degree of obesity, waist-to height ratio (WtHR) and waist circumference (WC) may define metabolic/cardiovascular risk. Its predictive value in childhood obesity is not clearly understood. The association between these three anthropometric measures and metabolic/cardiovascular risk markers has been analyzed herein.

Subjects and Methods: BMI(SDS), WtHR(SDS), and WC(SDS) were evaluated in 1288 patients for whom complete anthropometric parameters, fasting insulin (FI) and fasting glucose (FG) measurements were available in the APV registry as documented by 25 centres (53\% boys, 11-18 years). Parameters were correlated - separately for genders and for pubertal stages - with systolic/ diastolic blood pressure, GOT, GPT; GGT, total cholesterol, HDL-C, LDL-C, triglycerides (TG), uric acid (UA), FI, FG, serum glucose 120' after on oral glucose load (2hG) and HOMA-IR, applying adjusted regression models.

Results: HOMA-IR and FI were most strongly correlated with BMI(SDS), whereas UA, HDL-C, GPT and GGT were most strongly correlated with WC(SDS). Systolic RR was significantly and to a similar degree correlated with BMI(SDS) and WC(SDS). All correlations could be observed separately for both genders and throughout all pubertal stages. However, the pattern of relationship changed during the course of pubertal development: prepubertal children showed stronger correlations between BMI(SDS) and metabolic/cardiovascular risk markers, whereas postpubertal children had stronger correlations between WC(SDS) and measured parameters, as already observed in adult patients. None of the parameters investigated showed a dependency on WtHR(SDS) that was superior over the other anthropometric markers. FG, 2hG, cholesterol, LDL, TG and GOT were neither significantly correlated to BMI(SDS), to WtHR(SDS), nor to WC(SDS)

Conclusions: Markers for insulin resistance seem to be more strongly correlated with BMI as measure for the degree of obesity, whereas UA, HDL-C, GPT and GGT seem to be more closely correlated with WC as marker of abdominal obesity. The pattern of relationship changes throughout pubertal development. WtHR does not seem to be of clinical importance that is superior over BMI and WC in predicting metabolic or cardiovascular risk related to childhood obesity. 
P03

\section{BINGE-EATING-STÖRUNG BEI ADOLESZENTEN: EINE RANDOMISIERTE PSYCHOTHERAPIESTUDIE}

Müller, R. ${ }^{1}$; Schmidt, R. $^{1}$; Tetzlaff, A. ${ }^{1}$; Hilbert, $A{ }^{1}$

${ }^{1}$ Universitätsmedizin Leipzig, Leipzig, Deutschland

Fragestellung: Aktuelle Forschungsergebnisse zeigen, dass die BingeEating-Störung (BED) eine prävalente Störung bei Adoleszenten darstellt. Die BED geht mit einer erhöhten Essstörungs- und allgemeinen Psychopathologie, geminderter Lebensqualität sowie Übergewicht und Adipositas einher. Trotz der klinischen Bedeutsamkeit sind derzeit keine jugendspezifischen Behandlungsansätze verfügbar. Ziel dieses Forschungsprojektes ist es, bei Jugendlichen mit BED die Wirksamkeit eines altersangepassten kognitiv-behavioralen Therapieprogramms (CBT), die Goldstandard-Behandlung für Erwachsene mit BED, zu evaluieren.

Methodik: In der monozentrischen randomisiert-kontrollierten klinischen Studie sollen 60 Jugendliche im Alter von 13 bis 18 Jahren, die gemäß des Diagnostischen und Statistischen Handbuchs Psychischer Störungen (DSM-IV-TR oder DSM-5) unter einer BED leiden, in die CBT oder eine Wartelistenkontrollbedingung randomisiert werden. Die Patienten werden prospektiv zur Baseline, Behandlungsmitte, nach Behandlungsende sowie sechs und zwölf Monate nach Interventionsende getestet. Die CBT konzentriert sich auf das Essverhalten, Körperbild sowie Stress und Emotionen. Der primäre Endpunkt ist die Anzahl der Tage mit Essanfällen, die mit einem state-of-the-art klinischen Interview erfasst werden. Sekundäre Erfolgsmaße umfassen u.a. die spezifische Essstörungs- und allgemeine Psychopathologie, psychische Komorbidität, den Selbstwert und die Lebensqualität.

Ergebnisse: Erste Auswertungen der bisher eingeschlossenen Patienten $\left(\right.$ mittleres Alter $=15,5 \pm 1,0$ Jahre; mittlerer BMI $\left.=31,7 \pm 4,6 \mathrm{~kg} / \mathrm{m}^{2}\right)$ zeigen, dass Jugendliche mit einer BED auf den Skalen Weight und Shape Concern stark erhöhte Werte im Vergleich zur Normstichprobe aufweisen und somit anderen Essstörungsgruppen ähnlich sind. Die Werte auf den Skalen Restraint und Eating Concern sind hingegen unauffällig. Des Weiteren zeigte sich eine als unterdurchschnittlich erlebte Lebensqualität sowie ein leicht depressives Beschwerdeerleben. Schlussfolgerung: Die Ergebnisse dieser laufenden Studie werden zur Implementierung von effektiven evidenzbasierten Behandlungsmöglichkeiten für Jugendliche mit BED beitragen. Da Jugendliche mit BED gefährdet sind, weiter an Gewicht zuzunehmen, kann die CBT auch zur Prävention einer exzessiven Gewichtszunahme dienen.

\section{P04}

\section{GEZÜGELTES ESSVERHALTEN BEI 11- UND 12 JÄHRIGEN MÄDCHEN: WIE BEEINFLUSSEN DIE SUBKOMPONENTEN UND DIE STÖRBARKEIT DIE NAHRUNGSAUFNAHME?}

\section{Adam, S. ${ }^{1}$; Westenhoefer, J. ${ }^{1}$, Martin, C. ${ }^{2}$}

${ }^{1}$ Hochschule für Angewandte Wissenschaften Hamburg, Hamburg,

Deutschland; ${ }^{2}$ University of the West of Scotland, Schottland

Einleitung: Gezügeltes Essverhalten unterteilt sich in zwei Subkomponenten, die rigide und flexible Kontrolle des Essverhaltens. Ziel dieser Studie ist, zu untersuchen, ob die flexible Kontrolle bei Mädchen mit einer besseren Selbstregulation der Nahrungsaufnahme assoziiert ist, wogegen die rigide Kontrolle eher mit einer hohen Beanspruchung de selbstregulierenden Prozesse einhergeht und demnach mit einer höheren Störbarkeit des Essverhaltens und gleichzeitig einer höheren Nahrungsaufnahme assoziiert ist.

Methode: In einer randomisierten kontrollierten Studie werden 11- und 12jährige Mädchen in zwei experimentellen Situationen aufgeteilt. In beiden Gruppen wird ein kurzer Videofilm angesehen, währenddessen die Mädchen Süßigkeiten und Chips ad libitum verzehren können. Während eine Gruppe einen Dokumentarfilm über Gesundheit und Ernährung anschaut, der kontrolliertes Essverhalten unterstützen sollte, schaut die zweite Gruppe einen Zeichentrickfilm an, der kontrolliertes Essverhalten erschweren und so eine höhere Nahrungsaufnahme begünstigen sollte. Die abhängige Variable ist die gesamte Kalorienauf- nahme. Rigide und flexible Kontrolle sowie die Störbarkeit des Essverhaltens wurden mittels Fragebogen erhoben. Es wurde eine multiple Regressionsanalyse mit diesen drei Variablen sowie dem Gewichtsstatus und die experimentelle Situation als mögliche Prädiktoren für die Nahrungsaufnahme durchgeführt.

Ergebnisse: Es nahmen 66 Mädchen an der Studie teil. Die Nahrungsaufnahme unterscheidet sich nicht signifikant in beiden Situationen. MRA identifizierte nur die Störbarkeit als einen signifikanten Prädiktor $(\mathrm{R} 2=0,22, \mathrm{p}=0,006)$. Eine separat für beide experimentelle Situationen durchgeführte MRA ergab, dass die Störbarkeit und der Gewichtsstatus einen größeren Einfluss auf die Nahrungsaufnahme hat, während die Mädchen den Dokumentarfilm anschauen $(R 2=0,59, \mathrm{p}<0,001)$, jedoch kaum einen während der Zeichentrickfilm geschaut wurde $(\mathrm{R} 2=0,07$, $\mathrm{p}=0,840$ ).

Schlussfolgerung: Die selbstregulierte Nahrungsaufnahme bei Mädchen scheint abhängig von dem Grad der Störbarkeit und dem Gewichtstatus zu sein. Einen Einfluss der rigiden bzw. flexiblen Kontrolle auf die Nahrungsaufnahme konnte bis jetzt noch nicht nachgewiesen werden. Es sind weitere Analysen und Untersuchungen notwendig, außerdem wird der Stichprobenumfang ausgeweitet.

\section{P05 \\ EINFLUSS EINER DIÄTETISCHEN GEWICHTSREDUKTION AUF DIE FETTGEWEBSVERTEILUNG UND DAS KARDIOMETABOLISCHE RISIKO BEI ÜBERGEWICHTIGEN UND ADIPÖSEN JUGENDLICHEN}

Fink, U. ${ }^{1}$; Johannsen, M. ${ }^{1}$; Later, W. ${ }^{2}$; Schautz, B. ${ }^{2}$; Heller, M. ${ }^{3}$; Müller, M.J.' ${ }^{2}$ Bosy-Westphal, A. ${ }^{2}$

${ }^{1}$ Institut für Humanernährung und Lebensmittelkunde, Christian-AlbrechtsUniversität zu Kiel, Kiel, Deutschland; ${ }^{2}$ Institut für Humanernährung und Lebensmittelkunde, Kiel, Deutschland; ${ }^{3}$ Klinik Für Diagnostische Radiologie, Kiel, Deutschland

Fragestellungen: Wie verändern sich Körperfettverteilung nach einer diätetischen Gewichtsreduktion bei übergewichtigen Jugendlichen? Zeigen diese Veränderungen eine Beziehung zur Verbesserung kardiometabolischer Risikofaktoren?

Methoden: 96 übergewichtige und adipöse Jugendliche nahmen an einer 10-wöchigen diätetischen Gewichtsreduktion teil (empfohlenes Energiedefizit von ca. $600 \mathrm{kcal} / \mathrm{d}$ ). Eine Untergruppe von $40 \mathrm{Mädchen}$ und Jungen (BMI-SDS 2,28 $\pm 0,45$ und 2,38 $\pm 0,45$; Alter 15,8 $\pm 1,1$ und $15,5 \pm 1,5$ Jahre) mit einer erfolgreichen Gewichtsabnahme $>3 \mathrm{~kg}$ wurde vor und nach der Diät mittels Ganzkörpermagnetresonanztomographie und Densitometrie auf ihre Körperzusammensetzung untersucht.

Ergebnisse: Die mittlere Gewichtsreduktion und Abnahme der prozentualen Fettmasse betrug bei Mädchen $6,0 \pm 3,8 \mathrm{~kg}$ und 4,9 $\pm 3,6 \%$ und bei Jungen $9,6 \pm 5,1 \mathrm{~kg}$ und 7,0 $\pm 4,5 \%$ (alle $\mathrm{p}<0,001$ ). Die relative Abnahme einzelner Fettdepots in Prozent des Ausgangsvolumens unterschied sich zwischen den Geschlechtern. Während bei Jungen die größte Abnahme im viszeralen Fettgewebe (VAT) bestand $(-30,7 \%)$ zeigten Mädchen die höchste Reduktion im adominellen subkutanen Fettgewebe (SAT $-17,3 \%$ ). Bei beiden Geschlechtern nahm das Fettgewebe der Extremitäten dagegen unterproportional ab $(-12,1--19,1 \%)$. Die Abnahme des VAT hing von dessen Ausgangswert vor der Diät $a b(r=0,60 ; p<0,005)$. Sowohl bei Mädchen als auch bei Jungen nahmen der LDL-, der Gesamtcholesterin- und der Leptinspiegel durch die Intervention signifikant $\mathrm{ab}(\mathrm{p}<0,01)$ während der Adiponektinspiegel unverändert blieb. Darüber hinaus war bei Jungen ein Abfall im systolischen und diastolischen Blutdruck, dem Insulinspiegel und HOMA-Index signifikant $(\mathrm{p}<0,05)$. Bei beiden Geschlechtern korrelierte die Abnahme des Leptinspiegels mit der Abnahme des SAT am Rumpf ( $\mathrm{r}=0,47$ und 0,63, $\mathrm{p}<0,05)$. Die Verbesserung der Triglyceridspiegel korrelierte bei den Jungen mit der Abnahme des SAT an den Armen und bei den Mädchen mit der Abnahme des VAT. Die Abnahme des Blutdrucks korrelierte bei den Jungen mit der Abnahme der Gesamtfettmasse.

Schlussfolgerung: Eine erfolgreiche Gewichtsreduktion war bei übergewichtigen Jugendlichen mit einer deutlichen Verbesserung der Körperzusammensetzung verbunden. Diese zeigte jedoch nur geringe Beziehungen zur Verbesserung kardiometabolischer Risikofaktoren. Dies 
könnte sowohl durch einen geringen Anteil an VAT als auch durch ein günstiges kardiometabolisches Risikoprofil bedingt sein.

\section{P06}

\section{EINFLUSS EINER MODERATEN DIÄTETISCHEN INTERVENTION AUF DEN GESUNDHEITSZUSTAND VON ÜBERGEWICHTIGEN KINDERN: ERGEBNISSE DER HOFI- STUDIE NACH DEM ERSTEN STUDIENJAHR}

Maier, I.B. ${ }^{1}$; Özel, Y. ${ }^{1}$; Stahl, C. ${ }^{1}$; Puchinger, S. ${ }^{1}$; Bischoff, S.C. ${ }^{1}$; Bergheim, $I^{1}$

${ }^{1}$ Institut für Ernährungsmedizin, Universität Hohenheim, Stuttgart, Deutschland

Einleitung: Weltweit haben die Prävalenz von Adipositas und der dami assoziierten metabolischen Folgeerkrankungen bei Kinder und Jugendlichen in den letzten 3 Jahrzehnten stark zugenommen. Neben einer generellen Überernährung wird in zunehmendem Maße auch eine zucker- und hierbei insbesondere eine fructosereiche Ernährung als Risikofaktor in der Entstehung von Übergewicht, Diabetes Typ 2 und des metabolischen Syndroms diskutiert. Vor diesem Hintergrund war es das Ziel der Hohenheimer-Fructose-Interventionstudie (HoFI-Studie) zu untersuchen, ob ein diätetisches Konzept, das primär auf die Veränderung eines Ernährungsparameters fokussiert war (Fructosereduktion $50 \%$ ), bei übergewichtigen Kindern einen positiven Einfluss auf Komponenten des metabolischen Syndroms hat.

Methoden: Insgesamt wurden 100 übergewichtige Kinder (BMI $>90$, Referenzperzentil) im Alter von 5 bis 8 Jahren in die Interventionsstudie eingeschlossen und zu gleichen Teilen auf die beiden Studiengruppen Interventionsgruppe (Fructosereduktion um $\sim 50 \%$, regelmäßige Schulungen) und Kontrollgruppe (Ernährungsverhalten beibehalten, einmalige Beratung zu Beginn der Studie auf Wunsch) aufgeteilt. Zu Beginn und am Ende des ersten Studienjahres wurden die anthropometrischen Daten sowie das Ernährungs- und Bewegungsverhalten der Kinder erhoben. Zur Erfassung des Gesundheitszustandes wurde ein Summenscore berechnet, der sich aus den Laborwerten (Lipidwerte, ALTKonzentration), dem Blutdruck und dem Ergebnis des OGTT der Kinder zusammensetzte.

Ergebnisse: Am Ende des ersten Studienjahres fanden sich bei den Kindern der Interventionsgruppe geringfügige Veränderungen in dem Ernährungs- und Bewegungsverhalten. Dies ging einher mit einem signifikant verringerten BMI-SDS (2,04 vs. $1,82, \mathrm{p}<0,05)$ sowie einer Verbesserung des Gesamtscores (2,8 vs. 2,6). Im Gegensatz dazu veränderten die Kinder der Kontrollgruppe ihr Ernährungsverhalten nicht, der BMI-SDS blieb konstant und der Gesamtscore war am Ende des ersten Studienjahres signifikant höher als zu Beginn der Studie (2,5 vs. 2,9, $\mathrm{p}<0,05$ ).

Schlussfolgerung: Die Ergebnisse nach dem ersten Studienjahr weisen darauf hin, dass ein moderates diätetisches Konzept, das primär auf die Veränderung eines Ernährungsparameters (Fructosereduktion um 50\%) fokussiert, einen positiven Einfluss auf den Gesundheitszustand von übergewichtigen Kindern im Vergleich zu einer „,normalen Ernährung“ haben kann.

Das Projekt wurde von dem BMBF gefördert (03105084 (IB)).
P07

\section{GESUNDHEITSBEZOGENE LEBENSQUALITÄT UND KRANKHEIT BEI GRUNDSCHULKINDERN MIT ABDOMINELLER ADIPOSITAS IN BADEN- WÜRTTEMBERG}

Kesztyüs, D. ${ }^{1}$; Prokopchuk, D. ${ }^{1}$; Schreiber, A. ${ }^{1}$; Wirt, $T^{1}{ }^{1}$; Kettner, S. ${ }^{1}$; Kobel, S. ${ }^{1}$; Dreyhaupt, J. ${ }^{2}$; Kilian, R. $^{3}$; Steinacker, J.M.

${ }^{1}$ Klinik für Innere Medizin II, Universität UIm, Ulm, Deutschland; ${ }^{2}$ Institut für Epidemiologie und Medizinische Biometrie, Universität UIm, UIm, Deutschland; ${ }^{3}$ Klinik Für Psychiatrie und Psychotherapie II, Universität Ulm, UIm, Deutschland

Ziel: Untersuchung von assoziierten Faktoren, Begleiterscheinungen und Folgen abdomineller (,zentraler") Adipositas bei Grundschulkindern in der „Baden-Württemberg Studie“.

Methoden: Anthropometrische Messungen wurden von geschultem Personal nach einem standardisierten Verfahren durchgeführt. Eltern machten in Fragebögen unter anderem Angaben zur gesundheitsbezogenen Lebensqualität (HRQoL) ihrer Kinder. Die Anzahl der Arztbesuche im zurückliegenden Schul- / Kindergartenjahr, die Krankheitstage (Fehltage) der Kinder und die Tage, die berufstätige Eltern wegen Erkrankung ihres Kindes zuhause bleiben mussten, wurden erfragt.

Ergebnisse: Von den 1888 untersuchten Kindern $(7,1 \pm 0,6$ Jahre $)$ waren 191 (10,1\%) nach BMI-Klassifikation (Kromeyer-Hauschild at al. 2001) übergewichtig oder adipös; 158 (8,4\%) Kinder wurden anhand ihres Waist to Height Ratio (WHtR) als zentral adipös eingestuft (WHtR $\geq 0,5$ ). Diese Kinder mussten im Durchschnitt 3,6-mal zum Arzt, die restlichen 2,9-mal. Kinder mit zentraler Adipositas waren 9,1 Tage krank, die übrigen 6,8. Berufstätige Eltern zentral adipöser Kinder mussten insgesamt 4,1 Tage (Mütter 3,2; Väter 0,9) zuhause bleiben, die restlichen 3,1 Tage (Mütter 2,5; Väter 0,6). Allerdings konnte nur für die Anzahl der Krankheitstage ein statistisch signifikanter Unterschied nachgewiesen werden $(\mathrm{p}<.05)$.

Die Einschätzung der HRQoL durch die Eltern zeigte in der Regressionsanalyse niedrigere Werte für zentral adipöse Kinder. In der visueller Analogskala (EQ5D-Y) lagen diese Kinder um 4,1 Punkte (95\% CI $[-6,0 ;-2,1])$ unter den übrigen Kindern. Der KINDL $^{R}$ Score zeigte signifikante Differenzen im Gesamtscore $(-1,9 ; 95 \%$ CI $[-3,8 ;-0,1])$ den Subskalen Familie $(-2,8 ; 95 \%$ CI $[-5,5 ;-0,1])$, Freunde $(-3,4 ; 95 \%$ CI $[-6,0 ;-0,9])$ und Psyche $(-2,6 ; 95 \%$ CI $[-4,9 ;-0,3])$.

Schlussfolgerung: Vorliegende Ergebnisse lassen eine höhere Anzahl von Krankheitstagen und Einschränkungen der gesundheitsbezogenen Lebensqualität bei zentral adipösen Kindern vermuten. Die negativen Auswirkungen erhöhter viszeraler Fettakkumulation sind somit bereits bei Kindern zu Beginn der Grundschulzeit feststellbar. Dies betont die dringende Notwendigkeit eines möglichst frühen Einsatzes gezielter Präventions- und Gesundheitsförderungsmaßnahmen.

\section{P08}

\section{ENTWICKLUNG, DURCHFÜHRUNG UND ÜBERPRÜFUNG EINER „ADIPOSITAS-MINI-SCHULUNG“ FÜR KINDER IM GRUNDSCHULALTER IN DER STATIONÄREN REHABILITATION}

Torbahn, G. ${ }^{1}$; Hellmond, F. ${ }^{2}$; Erdmann, J. $^{1}$; Jaeschke, . $^{2}$

${ }^{1}$ Hochschule Weihenstephan-Triesdorf, Triesdorf, Deutschland;

${ }^{2}$ Fachkliniken Wangen, Rehabilitationsklinik für Kinder und Jugendliche, Wangen, Deutschland

Einleitung und Zielsetzung: $15,4 \%$ der Kinder im Alter von 7 bis 10 Jahren sind bereits übergewichtig. Übergewicht bei Kindern im Vorund Grundschulalter ist ein Risikofaktor für fortschreitendes Übergewicht im Jugendlichen- und Erwachsenenalter. Interventionen sollten so früh wie möglich begonnen werden. Standardisierte, interdisziplinäre Adipositasschulungen sind zentraler Bestandteil von stationären Rehabilitationsmaßnahmen bei Kindern mit Übergewicht. Hier können entsprechende Patientenschulungen bereits mit Kindern im Grundschulalter mit begleitender Elternschulung optimal durchgeführt werden. Zielsetzung 
dieser Arbeit ist die Konzeption, Durchführung und kritische Erprobung einer entsprechenden „Adipositas-Mini-Schulung“.

Methodik: Das Konzept der „Adipositas-Mini-Schulung“ beinhaltet 6 ausgearbeitete Einheiten (45 Min) mit max. $8 \mathrm{TN}$ im Grundschulalter während eines Reha-Aufenthaltes. Themen sind: „Einführung“, „Mein Körper“, „Ernährung“, „Essverhalten“, „Bewegung/Sport“ und „Umsetzung". Während des Reha-Alltags erproben die Pat. die erlernten Verhaltensweisen und werden dabei von ihren Eltern unterstützt, die auch eine Elternschulung erhalten. Grundlage ist das KgAS-Schulungskonzept. Lernziele und Methoden wurden den entwicklungspsychologischen Besonderheiten der Pat. angepasst, entsprechende Materialien angefertigt. Eine qualitative Evaluation erfolgt durch kritische Eigenreflexion, interdisziplinär durchgeführte Videoanalysen aller Einheiten und Befragungen der beteiligten Patienten und Eltern.

Ergebnisse: Eigeninitiative und Selbständigkeit der Kinder bei der Realisation relevanter Verhaltensweisen verbesserten sich nach Einschätzung der Begleitpersonen. Handlungsrelevantes Wissen über Ernährung, Bewegung und Übergewicht wurden gesteigert. Die für die Motivation förderliche Freude an der Schulung und an der Umsetzung sinnvoller Verhaltensweisen wurde von den Pat. und den Begleitpersonen bestätigt.

Schlussfolgerung: Kinder mit Übergewicht sollten bereits im Grundschulalter unter Berücksichtigung der entwicklungspsychologischen Besonderheiten und besonderer didaktischer Methoden in den Therapieverlauf aktiv einbezogen und standardisiert geschult werden. Die „Adipositas-Mini-Schulung" für Grundschulkinder konnte wie geplant in das Rehabilitationskonzept integriert werden. Die Stundeninhalte müssen teilweise auf die jeweiligen TN angepasst werden. Die vielversprechenden Ergebnisse werden bei einer größeren Zielgruppe und über einen längeren Zeitraum erprobt.

\section{Grundlagenforschung}

\section{P15}

\section{INTERLEUKIN-1 BETA DOWN-REGULATES RBP4 SECRETION IN HUMAN ADIPOCYTES}

\section{Kotnik, $P^{1,2}$; Keuper, M. $^{1}$; Wabitsch, M. ${ }^{1}$; Fischer-Posovszky, $P$.}

${ }^{1}$ Sektion Pädiatrische Endokrinologie und Diabetologie, Abt. Kinder- und Jugendmedizin, Universitätsklinikum UIm, Ulm, Deutschland; ${ }^{2}$ Department of Pediatric Endocrinology, Diabetes and Metabolism, University Children's Hospital, UKC Ljubljana, Ljubljana, Slovenia

Background: Obesity is a state of low-grade inflammation associated with an altered adipocyte ecretion profile, causally leading to its metabolic complications. Retinol binding protein 4 (RBP4) is an adipokine implicated in these complications, especially insulin resistance.

Objective: To determine the effect of an inflammatory environment on RBP4 expression and secretion in human adipocytes. Methods. Human adipocytes were cultured with conditioned media from human THP-1 macrophages (MacCM) or selected cytokines (TNFalpha, IL-1beta, IL-6 and IL-8). RBP4 production was studied by quantitative real-time PCR and ELISA. The correlation between RBP4 and IL-1 beta mRNA expression was studied in human adipose tissue explants.

Results: RBP4 mRNA expression and secretion was significantly reduced upon incubation with MacCM in SGBS (by 70\% using 10\% MacCM for $48 \mathrm{~h}$ )as well as in human primary adipocytes. IL-1beta was identified as a new and potent cytokine regulating RBP4, as it downregulated RBP4 mRNA and secretion in a time- and dose-dependent manner (inhibition by $\sim 50 \%$ at $50 \mathrm{ng} / \mathrm{ml}$ after $48 \mathrm{~h}$ ). Blocking IL-1beta signalling using a neutralizing IL-1R and a NFkB inhibitor (CAPE) abrogated the inhibitory effect of IL-1beta on RBP4 production. Most interestingly, RBP4 mRNA was negatively correlated with IL-1beta mRNA in subcutaneous adipose tissue obtained from 18 healthy female subjects $(\mathrm{R}=-.535 ; \mathrm{p}<0.05)$.

Summary \& Conclusions: RBP4 expression and secretion was inhibited in an in vitro model of inflamed adipose tissue. IL-1beta was identified as a new and potent inhibitor of RBP4 production. Adipose tissue inflammation and increased RBP4 levels are associated with the development of insulin resistance. We found that inflammatory conditions lead to a downregulation of RBP4 in adipocytes suggesting that adipose inflammation and the increase in circulating RBP4 are two unrelated processes.

\section{P16 \\ PALONOSETRON A SEROTONIN-RECEPTOR-3- ANTAGONIST IMPROVES OBESITY-ASSOCIATED FATTY LIVER DISEASE IN MICE}

Ritze, Y. ${ }^{1}$; Ehrmann, ${ }^{1}{ }^{1}$; Bárdos, G. ${ }^{1}$; Bischoff, S.C. ${ }^{1}$

${ }^{1}$ Institut Für Ernährungsmedizin, Universität Hohenheim, Stuttgart, Deutschland

Obesity is a major cause for nonalcoholic fatty liver disease (NAFLD). Previous studies suggested that alterations in intestinal motility and permeability contribute to the development of NAFLD. Serotonin and serotonin receptor 3 are key factors in the regulation of intestinal motility and permeability. Therefore, we studied the effect of the specific 5HT3R antagonist palonosetron on the development of NAFLD in leptindeficient obese mice. Four to six-week-old ob/ob mice and lean controls were treated for 6 weeks orally with palonosetron at $0.2 \mathrm{mg} / \mathrm{kg}$ per day. We determined physiological parameters, liver fat accumulation, portal endotoxin levels, and the tight junction protein occludin. Palonosetron treatment significantly reduced the liver to body ratio $(15 \%)$, the liver triglyceride content (32\%) and portal endotoxin $(77 \%)$ in ob/ob mice. The beneficial effects of palonosetron were accompanied by a $30 \%$ decrease of tumor necrosis factor-a mRNA expression in the liver and a $130 \%$ increase of occludin in the duodenum. In conclusion palonosetron is effective in attenuating NAFLD in a genetic mouse model of obesity.

\section{$\mathrm{P} 17$}

\section{BIOENERGETIC PROFILING OF HUMAN WHITE FAT CELLS DURING ADIPOGENESIS USING THE SGBS PREADIPOCYTE CELL STRAIN}

Keuper, M. ${ }^{1}$; Jastroch, M. ${ }^{2}$; Fischer-Posovszky, $P^{3}$; Wabitsch, M. ${ }^{3}$; Tschöp, M.H. ${ }^{2}$; Hofmann, S.M. ${ }^{1}$

${ }^{1}$ Institute of Experimental Genetics, Helmholtz Zentrum München, München, Germany; ${ }^{2}$ Institute of Diabetes and Obesity, Helmholtz Zentrum München, München, Germany; ${ }^{3}$ Sektion Pädiatrische Endokrinologie und Diabetologie, Abt. Kinder- und Jugendmedizin, Universitätsklinikum UIm, UIm, Deutschland

Background: Mitochondrial (dys-)function in the white adipose tissue has been suggested as a potential drug target for metabolic disorders such as obesity and diabetes. Translational attempts to target energy metabolism of white adipocytes require a fundamental understanding and profiling of adipocyte bioenergetics, in particular in the human situation. Here, we applied sophisticated technology to characterize adjustments of human adipocyte energy balance during adipogenesis using the established SGBS fat cell system.

Methods: We first established measurements of plate-based respirometry and acidification rates in intact cell culture using an extracellular flux analyzer.

Results: Herein we found that basal respiration and glycolysis rates increased during differentiation demonstrating higher cellular ATP demand. Using specific pharmacological inhibitors, we partitioned cellular respiration in mitochondrial and non-mitochondrial; and mitochondrial respiration in ATP synthesis, proton leak and maximal substrate oxidation. Mitochondrial respiration increased during differentiation. The increase of spare respiratory capacity suggests that basal respiration is controlled. We calculated the relative proportion of glycolysis (calculated with $\mathrm{P} / \mathrm{H}+$ ratio $=1$ ) and oxidative phosphorylation (calculated with $\mathrm{P} / \mathrm{O}$ ratio $=2.3$ ) to ATP homeostasis during adipogenesis, showing surprisingly low mitochondrial contribution. Inhibition of mitochondrial ATP synthase (with oligomycin) or respiratory complexes (with rotenone/antimycin) results in minor compensatory elevation of glycolytic ATP synthesis, although the capacity of glycolytic flux is much higher (indirectly induced by mitochondrial uncoupler FCCP). Summary and Conclusion: Taken together, the comprehensive dissection of bioenergetics pathways reveals increasing energy demand in maturing adipocytes, which is mainly fueled by glycolysis. Oxidative 
ATP production appears to be dispensable for ATP homeostasis under our cell culture conditions but respiration may have a role for other coupled cellular processes such as NAD+/NADH ratio, ROS or TCA cycle. The bioenergetic characterization of this human adipocyte model will assist future screens to test and manipulate adipocyte energy homeostasis and its dysregulation in metabolic disorders.

\section{P18}

\section{EVALUATION OF ASYMMETRIC DIMETHYLARGININE (ADMA) IN HUMAN ADIPOSE TISSUE BY MICRODIALYSIS}

May, M. ${ }^{1}$

${ }^{1}$ Institute of Clinical Pharmacology and Institute of Molecular and Translational Therapeutic Strategies, Hannover Medical School, Hannover, Germany

Introduction: Circulating concentrations of ADMA, the endogenous inhibitor nitric oxide (NO) synthesis, are higher in obese than in lean subjects. DDAH is the main enzyme responsible for ADMA metabolism and elimination. Elevated plasma ADMA concentration is linked to impaired glucose tolerance and diabetes. Yet, nothing is known about adipose tissue ADMA concentrations and DDAH activity and their role in diabetes and obesity. We hypothesized that tissue ADMA concentrations are associated to impaired glucose tolerance.

Methods: A sensitive GC-MS/MS method to measure interstitial tissue ADMA concentrations using microdialysis (MD) was evaluated. With clinical MD, adipose tissue ADMA concentrations were assessed before and during an oral glucose tolerance test (oGTT) in different study populations: in four diabetic and four lean subjects, and in seven morbidly obese subjects before and after a $30-\mathrm{kg}$ weight loss. In order to evaluate local ADMA metabolism, DDAH activity was determined in subcutaneous and omental adipose tissue derived from five subjects undergoing laparoscopic surgery.

Results: Circulating ADMA concentrations were $398 \pm 31 \mathrm{nM}$ in healthy subjects and $444 \pm 31 \mathrm{nM}$ in diabetics, as well as $509 \pm 19 \mathrm{nM}$ and $508 \pm 27$ $\mathrm{nM}$ before and after weight loss $(\mathrm{p}<0.01$ healthy $v s$. morbidly obese) Mean interstitial ADMA concentrations as determined by MD did no differ in the study populations (healthy $173 \pm 33 \mathrm{nM}$; diabetic $213 \pm 33$ $\mathrm{nM}$; morbidly obese before $161 \pm 14 \mathrm{nM}$ and $170 \pm 14 \mathrm{nM}$ after weight loss). We did not observe any response of interstitial ADMA concentrations to the oral glucose challenge, independent of the study population. Evaluation of adipose tissue DDAH activity revealed a negligible activity compared to the DDAH-rich liver as positive control $(5500 \pm 2700 \mathrm{vs}$ $8 \pm 5 \mathrm{fmol} / \mathrm{min} \times \mathrm{mg}$ tissue).

Conclusion: Glucose stimulation and impaired glucose tolerance do not alter subcutaneous adipose tissue ADMA concentrations in different study populations. Considering the very low adipose tissue DDAH activity, ADMA seems to play a negligible role in adipose tissue metabolism.

\section{P19}

\section{ERNIEDRIGTE GESCHMACKSPERZEPTIONS- SCHWELLEN FÜR BITTER UND UMAMI MAGEN-BYPASS OPERATION BEI STARK ADIPÖSEN PATIENTEN}

Ullrich, J. ${ }^{1}$; Wilms, B. ${ }^{1}$; Ernst, B. ${ }^{1}$; Thurnheer, M. ${ }^{1}$; Schultes, B. ${ }^{1}$

${ }^{1}$ Interdisziplinäres Adipositas Zentrum, Kantonsspital St. Gallen, Rorschach, Schweiz

Fragestellung: Magen-Bypass (MB) Operationen haben einen starken Einfluss auf das Essverhalten und die Ernährungsgewohnheiten von stark adipösen Personen. Die zugrundeliegenden Mechanismen sind bisher nur unvollständig geklärt. Wir überprüften die Hypothese, dass die MB Operation Geschmacksperzeptionsschwellen beeinflusst.

Methodik: Es wurden 32 stark adipöse Patienten (9 Männer) vor und 3 Monate nach einer MB Operation untersucht. Die Perzeptionsschwellen für Süss, Salzig, Sauer, Bitter und Umami wurden mittels eines standardisierten Geschmackserkennungstest bestimmt. Zudem bewerteten die Probanden eine Reihe von hochkalorisch süssen (hcs) und nicht-süssen (hcns) sowie niedrigkalorischen (lc) Essensbildern auf einer „Liking“und ,Wanting“-Skala. Das Essverhalten wurde mittels des „Fragebogen zum Essverhalten“ (FEV) sowie der „Power of Food Scale“ (PFS), welche den hedonischen Antrieb zum Konsum von schmackhaften Lebensmitteln misst, erfasst.

Ergebnisse: Drei Monate postoperativ war der BMI von präoperativ $43,6 \pm 0,9 \mathrm{~kg} / \mathrm{m}^{2}$ auf $35,5 \pm 0,7 \mathrm{~kg} / \mathrm{m}^{2}$ gesunken. Die Patienten wiesen postoperativ deutlich höhere Skalenwerte für „,kognitive Kontrolle“ und geringere Skalenwerte für „Störbarkeit“ sowie „Hunger“ auf, und auch der hedonische Antrieb zum Essen war vermindert (alle $P<0,001$ ). Die Bewertung sowohl der hes als auch der hons Essensbilder war auf der „Liking“- und „Wanting“-Skala postoperativ verringert (beide $P<0,05$ ), jedoch nicht die bezüglich der lc Bilder $(\mathrm{P}>0,17)$. Die Perzeptionsschwellen für Bitter und Umami waren postoperativ erniedrigt (beide $P<0,05$ ), die für Süss, Salzig und Sauer jedoch nicht signifikant verändert. Schlussfolgerung: Unsere Ergebnisse zeigen deutliche Veränderungen im Essverhalten sowie in der Lebensmittelpräferenz von stark adipösen Patienten nach einer MB Operation. Die postoperative Erniedrigung der Perzeptionsschwellen für Bitter und Umami legt nahe, dass die Operation einen Einfluss auf die neuronale Verarbeitung von Geschmacksreizen hat, was möglicherweise wiederum das Essverhalten beeinflusst.

\section{$\mathrm{P} 20$}

\section{THE IMPACT OF OBESITY AND GENDER ON PROBABILISTIC STIMULUS-RESPONSE LEARNING}

\author{
Mathar, D. ${ }^{1}$; Neumann, J. ${ }^{1}$; Pleger, B. ${ }^{1}$; Villringer, A. ${ }^{1}$; \\ Horstmann, A. $^{1}$ \\ ${ }^{1}$ Max Planck Institute for Human Cognitive and Brain Sciences, Leipzig, \\ Germany
}

Introduction: We investigated obesity- and gender-related differences in learning performance, strategy use and BOLD activation patterns within the Weather Prediction Task (WPT, Knowlton et al., 1994) which is a probabilistic stimulus-response learning task.

Methods: 59 healthy participants (30 female, 15 obese [BMI $>=30$, $<40$ ], 15 lean [BMI $>=19,<=25], 29$ male, 16 obese), matched for educational background and age (19-35 years), performed 200 trials of the WPT, interleaved with 60 motor-baseline trials, in an event-related design inside a 3 T TIM TRIO Siemens MRT(Siemens, Erlangen, Germany). Learning performance and subjects' strategy use were each analyzed in 4 equally sized blocks of trials. Strategies were determined based on maximum likelihood estimation of a computational model for different learning strategies (Meeter et al., 2006). BOLD activation differences were investigated utilizing a full-factorial GLM approach including gender, obesity and session as factors and age as covariate. Reaction times and number of visible cues per trial were also included as parametric modulators.

Learning Performance: A repeated measures ANOVA revealed a significant main effect of obesity $(F(1,54)=5.99, p<0.05)$ showing a decreased learning performance of obese subjects over the entire task. This effect was primarily driven by female participants $(F(1,27)=7,90$, $\mathrm{p}<0.01)$.

Strategy Use: We compared strategy use with respect to the number of considered cues. Lean subjects used significantly more often multi-cue strategies than obese subjects $(\mathrm{F}(1,54)=13.58, \mathrm{p}<0.001)$. This effect was again driven by female subjects $(\mathrm{F}(1,27)=13.49, \mathrm{p}<0.001)$.

Imaging: We identified BOLD activation differences for lean compared to obese subjects in a widespread network of cortical and subcortical structures known to be involved in learning and cognitive control related processes, as lateral prefrontal cortex, parahippocampus and precuneus. The most pronounced BOLD activation differences were revealed for lean compared to obese women, mirroring the behavioural findings.

Conclusion: Our results indicate an influence of obesity and gender as modulating factors on stimulus-response learning performance, on respective strategy use and on related BOLD activation patterns in a task requiring the integration of multiple cues for decision-making.

\section{References}

Knowlton et al., Learn. Mem. 1:106-120, 1994

Meeter et al., Learn. Mem. 13:230-239, 2006. 


\section{P21}

\section{LOADING CONTROLS FOR WESTERN BLOT ANALYSIS IN ADIPOSE TISSUE}

Skurk, ${ }^{1}{ }^{1}$; Matthä, S. ${ }^{1}$; May, S. ${ }^{1}$; Hauner, $H^{1}$

${ }^{1}$ Technische Universität München, Else Kröner-Fresenius-Zentrum für Ernährungsmedizin, München, Deutschland

To study adipose tissue function various in vitro models are used. Usually, measurements of proteins of interest are normalized to so-called housekeeping proteins (HK). However, adipose differentiation, cell hypertrophy or donor variations cause fluctuations in protein content. Therefore, aim of this study was to characterize frequently used HKs during adipose differentiation, in fat cells of varying cell size and different subjects to allow a reliable and robust data interpretation.

Primary human adipocyte precursor cells, human SGBS preadipocytes and murine 3T3-L1 cells were differentiated into fat cells using established procedures. At different time points, cells were harvested to investigate selected housekeeping proteins by Western blot analysis. In addition, freshly isolated mature adipocytes were separated according to fat cell size to study $\mathrm{HK}$ protein expression.

In primary adipocyte precursor cells, glycerolaldehyde-3-phosphate dehydrogenase (GAPDH) was the most stable internal control, whereas $\beta$-actin, $\alpha$-tubulin and hypoxanthine-guanine phosphoribosyltransferase (HPRT) showed substantial variation in their levels. In SGBS and 3T3L1 cells, neither $\beta$-actin, $\alpha$-tubulin, histone 3, GAPDH, nor HPRT, showed stable protein expression during differentiation. However, in primary human mature adipocytes GAPDH and $\alpha$-tubulin were found to be suitable as internal loading controls. There was no substantial variation between different donors. Furthermore, Coomassie-staining of proteins turned out to represent an appropriate alternative as a stable and highly sensitive internal standard for all cell models tested.

In conclusion, standard housekeeping proteins have substantial limitations in studies of adipogenesis and in dependence of fat cell size. Coomassie-staining turned out to be a sensitive and stable alternative as internal control for Western blot studies during adipogenesis. However, inter-subject variability was low for the recommended HK.

The studies were supported by grants from the European Commission [hepatic and adipose tissue (HEPADIP) LSHM- CT-2005-018734] and the Kompetenznetz Adipositas (Competence Network for Obesity) funded by the Federal Ministry of Education and Research (FKZ 01GI0832).

\section{P22}

\section{SEX-SPECIFIC IMPACT OF COMMON GENETIC VARIATION NEAR MC4R ON BRAIN STRUCTURE AND EATING BEHAVIOR PATTERNS}

Horstmann, A. ${ }^{1}$; Kabisch, S. ${ }^{2}$; Kovacs, $P^{3}{ }^{3}$; Schlögl, $H^{2}{ }^{2}$; Pleger, $B{ }^{1}{ }^{1}$; Stumvoll, . $^{4}$; Villringer, $A^{1}{ }^{1}$

${ }^{1}$ Max Planck Institute for Human Cognitive and Brain Sciences, Leipzig, Germany; ${ }^{2}$ Department of Medicine, University of Leipzig, Leipzig, Deutschland; ${ }^{3}$ Interdisciplinary Center of Clinical Research, University of Leipzig, Leipzig, Germany; ${ }^{4}$ IFB Adiposity Diseases, Leipzig, Germany

Introduction: Recent genome-wide association studies yielded severa BMI- and weight-associated variants located near genes expressed in the brain and affecting neural development or activity (Thorleifsson et al. Nat Gen. 2009). This includes $M C 4 R$, which is part of the central melanocortin system. The $\mathrm{MC}_{4}$ receptor is expressed in regions of the brain affecting feeding regulation. Recently, a single nucleotide polymorphism (SNP), mapping to a locus $188 \mathrm{~kb}$ downstream of $M C 4 R$ (rs17782313), has been shown to be strongly associated with the risk of obesity. Here, we hypothesized a link between SNP dependent alterations in eating behavior and human brain structure. Therefore, we examined effects of common variants of rs17782313 near $M C 4 R$ on brain structure and eating behavior as measured with the Three-Factor-Eating Questionnaire (TFEQ) in a sample of healthy young Europeans $(\mathrm{n}=192)$. Methods: 192 subjects were genotyped for rs17782313 near MC4R (minor allele G: 15 GG, 77 GA, 100 AA), completed the TFEQ (Stunkard and Messink J Psychosom Res. 1985) and underwent magnetic resonance (MR) imaging. We applied both the TFEQ-51 and the TFEQ-18 scoring scheme to form subscales. T1-weighted, whole-head
3D MP-RAGE structural MR images were recorded at 3 Tesla (Magnetom TIM Trio, Siemens, Erlangen, Germany) using a 12-channel head array coil. Images were processed using the DARTEL approach under SPM5 with standard parameters for VBM running under MatLab 7.7 (Mathworks, Sherborn, MA, USA). All analyses were performed on bias-corrected, segmented, registered (rigid-body transformation), interpolated isotropic $(1.5 \mathrm{~mm} \times 1.5 \mathrm{~mm} \times 1.5 \mathrm{~mm})$, and smoothed (FWHM $8 \mathrm{~mm}$ ) images. The general linear model was estimated with the factors genotype at rs17782313 and gender; age in years, BMI in $\mathrm{kg} / \mathrm{m}^{2}$, total gray matter volume and total white matter volume in $\mathrm{ml}$ were included as covariates.

Results: Carriers of the risk allele had a significant higher disinhibition score on the TFEQ-51. This effect was more pronounced for women than men. Adopting the TFEQ-18 scoring scheme, we found a similar but stronger effect of genotype on emotional eating. Furthermore, genotype at MC4R had a significant effect on brain structure in bilateral medial orbitofrontal cortex, right amygdala/hippocampus and left prefrontal cortex. Again, we observed a significant interaction between genotype and gender for structural alterations. For women only, gray matter volume correlated with emotional eating scores in all identified brain areas.

Conclusion: The effect of common genetic variation near MC4R on eating behavior in humans may be mediated through central mechanisms involving amygdala and medial OFC.

\section{P23 \\ CIRCADIAN RHYTHM OF BLOOD ENDOCANNABINOIDS - IS FOOD INTAKE THE KEY TRIGGER?}

\section{May, M. ${ }^{1}$; Batkai, S. ${ }^{1}$; Zoerner A.A. ${ }^{1}$; Tsikas, D. ${ }^{1}$; Jordan, J. ${ }^{1}$;} Engeli, $S$.

${ }^{1}$ Institute of Clinical Pharmacology and Institute of Molecular and Translational Therapeutic Strategies, Hannover Medical School, Hannover, Germany

Introduction: The endocannabinoid system (ECS) is involved in many fundamental physiological processes, including energy homeostasis. Several physiological processes follow a circadian rhythm and circadian rhythm disturbances have been discussed as contributors for the development of obesity. The purpose of these pilot studies was to assess circadian changes of blood endocannabinoids in humans and to establish the role of food intake as a possible trigger.

Methods: Anandamide (AEA), 2-AG, and plasma cortisol concentrations were measured at defined time points during a standardized 24 hour period ( $\mathrm{n}=4$ healthy subjects). Plasma endocannabinoids were also measured in 28 subjects before, 30, 60, 90 and 120 minutes after eating a low or high fat test meal on two different days in a randomized cross-over fashion. AEA and 2-AG were determined in plasma by LCMS/MS using deuterated internal standards. Cortisol was measured by ELISA.

Results: Plasma AEA concentrations were higher during the day compared to night-time $(0.50 \pm 0.01$ vs. $0.44 \pm 0.02, \mathrm{p}<0.05) .2-\mathrm{AG}$ did not differ between day and night $(1.85 \pm 0.88$ vs. $1.63 \pm 0.70)$. Cortisol followed its well known circadian rhythm, but no close correlation between endocannabinoids and cortisol was observed. During the 24 hour daily cycle, AEA plasma concentrations were significantly higher before compared to 120 minutes after eating. This phenomenon was more pronounced with breakfast and lunch, and diminished at the last meal of the day. In our standardized test meal study, plasma AEA concentrations rapidly decreased after initiation of food intake, and were significantly reduced at 30, 60, 90 and 120 minutes after eating compared to baseline. We obeserved a more rapid and sustained decrease in AEA concentrations after a low fat meal compared to a high fat meal, but areas under the curve were not significantly different $(p=0.06)$. In both studies, postprandial changes of plasma $2-\mathrm{AG}$ concentrations never reached statistical significance.

Conclusions: The most prominent trigger for AEA changes during the day is food intake. A rise of AEA in the hypothalamus with fasting, and a decrease after eating has been described in animals. Distinct minor circadian changes of blood AEA, but not 2-AG, following a circadian rhythm with lower concentrations during the night, may be discovered 
in a larger group of subjects. Investigations on the contribution of endocannabinoid signaling to circadian physiological changes are warranted.

\section{P24 \\ FATTY ACID BINDING PROTEIN 4, LEFT VENTRICULAR MASS AND LONGITUDINAL CARDIAC CONTRACTILITY BEFORE AND AFTER A SIX MONTH DIET IN OBESE WOMEN}

Engeli, S. ${ }^{1} ;$ Utz, W. ${ }^{2}$; Haufe, S. ${ }^{1}$; Lamounier-Zepter, . $^{3}$; Pofahl, M. ${ }^{2}$; Traber, J. ${ }^{2}$; Boschmann, M. ${ }^{4}$; Schulz-Menger, J. ${ }^{2}$; Jordan, J. ${ }^{1}$

${ }^{1}$ Institute of Clinical Pharmacology, Hannover Medical School, Hannover, Germany; ${ }^{2}$ Working Group Cardiac MR at the Experimental and Clinical Research Center, Charité University Medical School, Berlin, Germany; ${ }^{3}$ Medical Clinic III, University Clinic Carl Gustav Carus, Dresden University of Technology, Dresden, Germany; ${ }^{4}$ Franz Volhard Clinical Research Center at the Experimental and Clinical Research Center, Charité University Medical School, Berlin, Germany

Introduction: Adipocyte or heart specific fatty acid binding proteins (FABP4 and FABP3) induced contractile dysfunction and cellular hypertrophy in isolated rat cardiomyocytes. As a consequence, increased serum FABP4 in obesity may predisposes to cardiac remodelling and left ventricular dysfunction.

Methods: In 108 obese non diabetic women, we assessed serum FABP4 concentrations, glucose metabolism, 24-hour ambulatory blood pressure (ABPM), and body composition including measurements of visceral and subcutaneous abdominal adipose tissue. We studied cardiac structure and function by cardiac magnetic resonance imaging. We stratified women into serum FABP4 tertiles $(49.5 \pm 9.6$ vs. $34.1 \pm 3.5$ vs. $22.9 \pm 4.4$ $\mathrm{ng} / \mathrm{ml}$ ), and conducted multivariate analyses including all samples.

Results: After stratification into serum FABP4 tertiles, left ventricular mass was $92 \pm 16 \mathrm{~g}, 86 \pm 13 \mathrm{~g}$ and $81 \pm 12 \mathrm{~g}$ in women with high, intermediate, and low serum FABP4 concentrations $(p<0.01)$. In a multivariate analysis including all samples, left ventricular end-diastolic volume, systolic ambulatory blood pressure and FABP4 serum concentrations independently predicted left ventricular mass (all $\mathrm{p}<0.01$ ). BMI was significantly higher in the highest FABP4 tertile $(34.4 \pm 5.2$ vs. $33.0 \pm$ 4.4 vs. $31.4 \pm 3.4 \mathrm{~kg} / \mathrm{m}^{2}$ ), but had no independend influence on LV mass. Longitudinal LV fractional shortening was 7\% lower amongst women in the upper two tertiles of FABP4 compared to those in the lowest FABP4 serum concentrations $(\mathrm{p}<0.05)$. Radial LV fractional shortening and ejection fraction were similar among groups. Heart rate, systolic ABPM, and FABP4 serum concentrations independently predicted longitudinal LV fractional shortening. A six months hypocaloric diet decreased FABP4. The changes in FABP4 independently predicted changes of left ventricular mass but not longitudinal fractional shortening.

Conclusion: Excessive FABP4 serum concentrations are directly correlated with left ventricular hypertrophy and contractile dysfunction in obese women. The dietary induced decrease of serum FABP4 directly correlated with the decrease in left ventricular mass. FABP4 may represent a link between adipose tissue mass accumulation and obesityassociated cardiac disease.

\section{P25}

\section{REGULATION OF G0/G1 SWITCH GENE 2 (G0S2) EXPRESSION IN HUMAN ADIPOSE TISSUE}

Skopp, A. ${ }^{1}$; May, M. ${ }^{1}$; Janke, J. ${ }^{2}$; Nave, H. $^{3}$; Wunder, R. ${ }^{4}$; Flade-Kuthe, R. ${ }^{4}$ Kuthe, A. ${ }^{4}$; Jordan, J. ${ }^{1}$; Engeli, S. ${ }^{1}$

${ }^{1}$ Institute of Clinical Pharmacology, Hannover Medical School, Hannover, Germany; ${ }^{2}$ Max-Delbrück Center for Molecular Medicine, Berlin, Germany; ${ }^{3}$ Institute of Anatomy and Cell Biology, Martin Luther University Halle, Halle, Germany; ${ }^{4}$ Surgical Department, Clementinenhaus, Hannover, Germany

Introduction: G0S2 is a target gene of PPARã and attenuated ATGL activity and lipolysis in rodent adipocytes. We determined depot- specificity, and the influence of adipogenesis, BMI, weight reduction, and glucose on G0S2 mRNA expression in human white adipose tissue. Methods: SGBS cells were differentiated in vitro. Subcutaneous (SAT) and omental adipose tissue (OAT) samples were obtained from control and obese patients during laparoscopic surgery. SAT samples from participants in several clinical studies were obtained by needle biopsy. Immunohistochemistry and TaqMan-RT-PCR were performed.

Results: G0S2 mRNA increased during in vitro adipogenesis of SGBS preadipocytes until day six. Accordingly, G0S2 mRNA was 7x stronger expressed in isolated mature adipocytes compared to preadipocytes $(\mathrm{n}=7 ; \quad \mathrm{p}<0.001)$. Immunhistochemistry demonstrated cytoplasmatic localization of G0S2 in adipocytes as well as in mononuclear and endothelial cells. G0S2 mRNA was $60 \%$ higher in SAT compared to paired OAT samples $(\mathrm{n}=36, \mathrm{p}<0.0001)$. We detected $75 \%$ higher G0S2 gene expression in SAT of lean $(n=11)$ compared to obese subjects $(n=22$; $\mathrm{p}<0.05$ ). A similar trend in OAT was not significant, although adipocyte size negatively correlated with G0S2 mRNA expression in this depot. Two weeks of high or low fat intake $(n=30), 5 \%$ body weight loss $(n=13)$, and glucose ingestion after an overnight fast $(n=10)$ did not change G0S2 mRNA expression in SAT. More pronounced weight loss after bariatric surgery appears to increase G0S2 expression, but interindividual variation is rather pronounced.

Conclusion: G0S2 is expressed in mature human adipocytes. Short time nutritional manipulation did not influence G0S2 mRNA levels in subcutaneous adipose tissue. Comparable to mice, we found decreased expression of G0S2 in adipose tissue of obese individuals. No clear-cut nutritional regulation was identified in our studies. The precise physiological role of G0S2 in humans needs to be further defined.

\section{P26}

\section{SGBS ADIPOCYTES AND THP-1 MACROPHAGES - A NEW IN VITRO MODEL OF INFLAMED ADIPOSE TISSUE}

Fischer-Posovszky, ${ }^{1}{ }^{1}$; Keuper, M. ${ }^{1}$; Zagotta, I. ${ }^{1}$; Debatin, K.-M. ${ }^{2}$; Wabitsch, M. $^{1}$

${ }^{1}$ Sektion Pädiatrische Endokrinologie und Diabetologie, Abt. Kinder- und Jugendmedizin, Universitätsklinikum Ulm, Ulm, Deutschland; ${ }^{2}$ Abt. Kinderund Jugendmedizin, Universitätsklinikum Ulm, Ulm, Deutschland

Background: Obesity is associated with an accumulation of macrophages in adipose tissue. This inflammation of adipose tissue is a key event in the pathogenesis of several obesityrelated disorders, particularly insulin resistance.

Objective: We sought to develop an in vitro model of inflamed adipose tissue to study the interaction of adipocytes and acrophages.

Methods: Human THP-1 monocytes were differentiated into macrophages by incubation with $125 \mathrm{ng} / \mathrm{ml}$ phorbol 12 -myristate 13 -acetate for $48 \mathrm{~h}$. Macrophage differentiation was controlled by flow cytometry. Macrophage-conditioned media (MacCM) were collected after $48 \mathrm{~h}$. Human SGBS preadipocytes and adipocytes were either cultivated with MacCM or directly cultured with THP-1 macrophages. Adipogenic differentiation, insulin-stimulated glucose uptake as well as lipogenesis, and secretion of adipokines were studied.

Results: Incubation with $10 \%$ MacCM or cu-culture of SGBS cells with macrophages at a ratio of $1: 1$ completely blocked adipogenic differentiation as seen by inhibition of triglyceride formation. Insulin-stimulated glucose uptake was robustly inhibited by MacCM 8inhibition by $50 \%$ at insulin $10 \mathrm{nM}$ and MacCM 10\%). Consequently insulin-stimulated de novo lipogenesis was blocked to a similar extent accompanied by reduced phosphorylation of Akt. Treatment with MacCM shifts the expression of adipokines towards a pro-inflammatory profile with increased expression of IL- 6 and IL- 8 and reduced expression of adiponectin. Summary and Conclusions: Perfectly mimicking the biology of inflamed adipose tissue in vivo, this in vitro model is a useful tool to study adipose inflammation in vitro. It can be easily extended for usage with human primary macrophages and fat cells. 
P27

\section{TRAIL (TNF RELATED APOPTOSIS INDUCING LIGAND) REGULATES HUMAN ADIPOCYTE METABOLISM BY CASPASE-MEDIATED CLEAVAGE OF PPARGAMMA}

Fischer-Posovszky, P. ${ }^{1}$; Keuper, M. ${ }^{1}$; Wernstedt Asterholm, I. ${ }^{2}$; Scherer, P.E. ${ }^{2}$; Möller, P. ${ }^{3}$; Westhoff, M.-A. ${ }^{4}$; Lehnert, C. ${ }^{4}$; Strauss, G. ${ }^{4}$; Debatin, K.-M. ${ }^{4}$; Wabitsch, M. ${ }^{1}$

${ }^{1}$ Sektion Pädiatrische Endokrinologie und Diabetologie, Abt. Kinder- und Jugendmedizin, Universitätsklinikum Ulm, Ulm, Deutschland; ${ }^{2}$ Department of Internal Medicine, Touchstone Diabetes Center, University of Texas

Southwestern Medical Center, Texas; ${ }^{3}$ Institut für Pathologie, Universitätsklinikum Ulm, Ulm, Deutschland; ${ }^{4}$ Abt. Kinder- und Jugendmedizin, Universitätsklinikum UIm, UIm, Deutschland

Background: Death ligands exert several biological functions independently of inducing apoptosis. As such, TNF $\alpha$ and FasL affect adipose tissue metabolism and thereby regulate systemic insulin sensitivity. Interestingly elevated serum concentrations of TRAIL are associated with increased serum lipid levels and increased adiposity. We have previously shown that human adipocytes are resistant to TRAIL-induced apoptosis although expressing significant amounts of TRAIL receptors. Here we hypothesized that TRAIL might exert so far unknown functions in adipose tissue.

Methods: Human SGBS adipocytes were used as an in vitro model to perform metabolic, signal transduction and expression analysis. Expression of TRAIL and TRAIL receptors was studied in murine and human adipose tissue samples. Male 6-8 week old C57/B6 mice were injected i.p. with $10 \mu \mathrm{g} / \mathrm{d}$ rhTRAIL.

Results: In SGBS adipocytes TRAIL inhibited insulin-stimulated glucose uptake and de novo lipogenesis in a dose dependent manner (inhibition by $\sim 50 \%$ for TRAIL $100 \mathrm{ng} / \mathrm{ml}$ at $10 \mathrm{nM}$ insulin). By binding to TRAIL-R2, it activated cleavage of caspase- 8 and -3 , which in turn cleaved and inactivated PPAR $\gamma$ resulting in reduced expression of lipogenic genes such as Glut-4, FASN, and ACC. In summary, TRAIL induced insulin resistance in human adipocytes. TRAIL-R2 and its mouse homologue DR5 were regulated upon acute and chronic energy imbalance in murine and human adipose tissue. Intriguingly, we detected the PPAR $\gamma$ cleavage product in vivo in adipose tissue lysates of mice injected with rhTRAIL.

Summary and Conclusions: Taken together we elucidated a so fa unknown function of the death ligand TRAIL in regulating adipocyte metabolism and discovered a new TRAILactivated signalling pathway. Our results imply that blocking TRAIL signaling in adipocyte might provide a new strategy to prevent obesity-induced insulin resistance. Furthermore, our findings have important implications for cancer research since agonistic TRAIL receptor antibodies are currently tested as anti-cancer agents.

P28

THE GTPASE ARFRP1 CONTROLS THE ASSEMBLY OF APOA-I TO AND THE LIPIDATION OF CHYLOMICRONS IN THE GOLGI OF THE INTESTINAL EPITHELIUM

Jaschke, A. ${ }^{1}$; Chung, B. ${ }^{1}$; Hesse, D. ${ }^{1}$; Kluge, R. ${ }^{1}$; Heeren, J. ${ }^{2}$; Joost, H.-G. '; Schürmann, A. ${ }^{1}$

${ }^{1}$ German Institute of Human Nutrition, Potsdam, Germany; ${ }^{2}$ University Medical Center Hamburg-Eppendorf, Hamburg, Germany

Background: The uptake and processing of dietary lipid by the small intestine is a multi-step process that involves luminal digestion, cellular uptake of fatty acids by the mucosa, and subsequent synthesis and export of chylomicrons. The GTPase ADP-ribosylation factor related protein 1 (ARFRP1) is a member of the ARF-family and controls the recruitment of scaffolding proteins that bind several Rab-GTPases. In adipose tissue ARFRP1 plays a crucial role for lipid droplet growth. The aim of the study was to define the role of ARFRP1 for intestinal lipid resorption.

Methods: For the generation of intestine-specific null mutants Arfrpl $1^{\text {floxflox }}$ mice were crossed with mice expressing the Cre recombinase under the control of the intestine-specific villin promoter (vilCre) and Arfrpl expression was suppressed by siRNA in Caco2-cells. The phenotype in respect to lipid absorption and chylomicron produc- tion in the intestinal epithelium and in Caco2-cells, respectively, was analyzed.

Results: Arfrp ${ }^{\text {vil-/- }}$ mice were viable but showed an early postnatal growth retardation (mean body weight of $A r f r p 1^{\text {vil-/ }}$ was $43.3 \pm 5 \%$ lower than that of control mice at the age of 28 days) Arfrp $1^{\text {vil-/ }}$ mice displayed reduced triglycerides, free fatty acids and glucose plasma levels indicating that the growth retardation is the result of a malabsorption. Uptake of glucose and amino acids were unaffected by the deletion of Arfrpl. In contrast, lipid uptake as elucidated by oral fat tolerance tests was impaired in Arfrp1 $1^{\text {vil-/ }}$ mice. Arfrpl ${ }^{\text {vil-- }}$ enterocytes as well as Arfrp1 mRNA depleted Caco- 2 cells absorbed fatty acids normally but secreted chylomicrons with a markedly reduced triglyceride content. In addition, while the release of apolipoprotein A-I (ApoA-I) was dramatically decreased ApoA-I accumulated in the Arfrp1 $1^{\text {vil- }-}$ epithelium and was predominantly co-localized with Rab2.

Conclusion: Our results demonstrate that ARFRP1 is required for the assembly of AopA-I to the chylomicrons and for the further lipidation of chylomicrons in the Golgi of intestinal epithelial cells. This finally leads to a secretion of chylomicrons with a markedly reduced triglyceride content.

\section{P29}

\section{NEURONAL CORRELATES OF WEIGHT CHANGE DURING LIFESTYLE INTERVENTION}

Hege, M. ${ }^{1}$; Stingl, K. T. ${ }^{1}$; Heni, M. ${ }^{2}$; Ketterer, C. ${ }^{2}$; Fritsche, A. ${ }^{2}$; Preissl, H. $^{1}$

${ }^{1}$ MEG Center, University Tübingen, Tübingen, Germany; ${ }^{2}$ Department of Internal Medicine, Division of Endocrinology, Diabetology, Angiology, Nephrology and Clinical Chemistry, Eberhard Karls University Tübingen, Tübingen, Germany

Objective: Lifestyle interventions to reduce body weight are still the most pursued options to treat obesity. However, the outcome of most lifestyle interventions (LI) and especially the ability to maintain obtained weight loss after LI over a longer period strongly differ between participants. In a recent study, we could show that high insulinstimulated resting cerebrocortical theta activity measured by magnetoencephalography before LI was associated with a reduction of total and visceral adipose tissue during LI. In the present study, we hypothesized that initial differences in food picture induced brain activation can predict weight change during LI.

Methods: We recorded magnetic brain activity and behavioural responses during a one-back visual memory task with food and non-food pictures in 33 overweight and obese subjects before they underwent LI. In short, the goal of LI was the reduction of the daily caloric intake by $400 \mathrm{kcal}$ during the next 6 months. Body mass index (BMI) was determined before and after LI. For further analysis, subjects were separated into three tertiles according to their change in BMI during LI.

Results: We report the differences between both outer tertiles representing people who increased their BMI by $1.4 \pm 1.1 \%$ (non-successful dieters) and who reduced their BMI by $-6.9 \pm 2.6 \%$ (successful dieters). Behavioural responses (reaction time and accuracy) did not reveal to be significantly different before LI between successful and non-successful dieters. However, neuronal activity was related to future change in BMI in sensor and source space. At the source level, non-successful dieters showed higher activation in right inferior frontal and left occipital visual areas, whereas successful dieters showed increased activation in mainly right temporal areas including hippocampus and fusiform gyrus.

Conclusion: Despite being equally obese, there are differences in the cerebral response during a food specific working memory task. These differences indicate an altered cognitive control over food intake, which in turn might determine the ability to eat less and successfully lose weight during LI. 
P30

\section{INFLAMMATORY AND METABOLIC ACTIVATION OF PBMC: A SUBJECT OF INTER-INDIVIDUAL DIFFERENCES}

Ehlers, K. ${ }^{1}$; Brand, T. $^{1}$; Hastreiter, L. ${ }^{2}$; Bangert, A. ${ }^{3}$; Hauner, $H^{1}{ }^{1}$; Laumen, $H^{1}{ }^{1}$

${ }^{1}$ Technische Universität München, Freising-Weihenstephan, Germany; ${ }^{2}$ Klinikum Rechts der Isar, Technische Universität München, München, Germany; ${ }^{3}$ Molecular Nutrition Unit, Technische Universität München, Freising-Weihenstephan, Germany

Objective: Postprandial nutrition challenge studies revealed that macronutrient intake induces oxidative and inflammatory stress in peripheral blood mononuclear cells (PBMC), especially when a meal is rich in saturated fat and refined carbohydrates (Dandona P et al., Exp Mol Med 2010). Exaggerated postprandial activation may contribute to the manifestation of chronic oxidative and inflammatory stress, two main pathomechanisms of T2DM and obesity. PBMC are known to respond to nutrients similarly to other cell types, and therefore nutrient sensing helps to maintain energy homeostasis, but under certain conditions immune cells may use metabolic pathways to control fate and function (Mathis D and Shoelson SE, Nat Rev Immunol, 2011).

The regulation of metabolic pathways in PBMC by nutritional challenges is poorly understood. To unravel the response of nutrient sensors to nutritive stimuli and the possible interaction with inflammation, we investigated the effect of a nutritional challenge on metabolic and inflammatory PBMC activation.

Methods: Six healthy male subject (age range: 40-53 years; weight range: $72.9-99.9 \mathrm{~kg}$; mean BMI: $24.8 \pm 2.5 \mathrm{~kg} / \mathrm{m}^{2}$ ) were given a lipid drink after an overnight fast. Blood samples were obtained at $0,1,2,4$, 6 and $8 \mathrm{~h}$. PBMC were isolated at each time point. Inflammatory activity was measured by EMSA and protein degradation as well as the activation of metabolism relevant kinases by means of proteinphosphorylation by Luminex xMAP technology (Millipore).

Results: We found strong inter-individual differences for each targe that was measured. We show the known proinflammatory activation and in addition an activation of kinases related to metabolic pathways. Notably, a parallel activation of intracellular inflammation markers and metabolism associated kinase activation was observed.

Conclusion: Defined nutritive challenges activate both, metabolic and inflammatory pathways in PBMC. A high number of postprandial blood withdrawals is essential to cope with inter-individual differences, and thereby enables the identification of differences in metabolic and inflammatory activation.

\section{Literatur}

Mathis D, Shoelson SE (2011) Immunometabolism: an emerging frontier. Nature Reviews Immunology 11(2):81.

Dandona P, Ghanim H, Chaudhuri A, Dhindsa S, Kim SS (2010) Macronutrient intake induces oxidative and inflammatory stress: potential relevance to atherosclerosis and insulin resistance. Exp Mol Med 42(4):245-53

P31

\section{FOOD.PICS: A PICTURE DATABASE FOR THE STUDY OF EATING AND APPETITE}

\section{Meule, A. ${ }^{1}$; Blechert, J. ${ }^{2}$}

${ }^{1}$ Department of Psychology I, University of Würzburg, Würzburg, Germany; ${ }^{2}$ Department of Clinical Psychology, Psychotherapy and Health Psychology, University of Salzburg, Salzburg, Austria

Aims: The effects of food-cues on behavioral, physiological and neuronal measures are an essential line of research for understanding normal and pathological eating behavior. Pictorial food stimuli are most commonly used in those studies. However, current stimulus sets are often poorly described and physical characteristics mostly unknown. Our aim was to develop a food picture database which provides fundamental information needed when using such pictures in experimental research.

Methods: Pictures of high-calorie foods $(n=190)$, low-calorie foods ( $n$ $=99$ ) and neutral objects $(n=37)$ were edited to be homogeneous with regard to background color, viewing distance and figure-ground compo- sition. Perceptual characteristics (RGB brightness and contrast) and visual complexity (jpg compression, edge detection) were analyzed. Calorie content and composition of macronutrients were estimated by a trained research assistant. Subjective ratings for complexity, palatability and craving were obtained in an online study in which pictures were randomly presented.

Results: A sample of $N=1024$ subjects $(73.20 \%$ women, $n=750)$ participated in the online study (age $M=23.71$ years \pm 4.18 , body-massindex (BMI) $\left.M=22.52 \mathrm{~kg} / \mathrm{m}^{2} \pm 3.60\right)$ and each picture was on average rated by approximately 250 participants $(M=250.59 \pm 12.97)$. Subjective ratings are presented for the total sample and for men and women separately. The different indices of complexity (jpg compression, edge detection, subjective ratings) were positively inter-correlated ( $r=.27$ $.70, p<.001)$. Ratings of palatability and craving were not correlated with body-mass-index or age.

Conclusions: The food.pics database provides a large array of pictorial food and neutral stimuli for experimental research. Its use could increase standardization and comparability across studies. Pictures can be selected - or picture sets matched - on several indices that are likely to influence biobehavioral information processing in studies of appetite, (hedonic) hunger, and normal and abnormal eating.

\section{P32 \\ FOOD CONTAMINANTS ALONE AND IN COMBINATION AFFECT ADIPOGENIC DIFFERENTIATION OF STEM CELLS}

Biemann, R. ${ }^{1}$; Blüher, M. ${ }^{2}$; Fischer, B. ${ }^{1}$; Navarrete Santos, $A .^{1}$

${ }^{1}$ Department of Anatomy and Cell Biology, Martin Luther University Faculty of Medicine, Halle, Germany; ${ }^{2}$ Department of Medicine, University of Leipzig, Leipzig, Germany

Background: Endocrine disrupting chemicals (EDC) like bisphenol A (BPA), bis(2-ethylhexyl)phthalate (DEHP) and tributyltin (TBT) are known to affect endocrine mediated pathways by binding to hormone receptors. Alterations of energy metabolism may contribute to the prevalence of obesity. Although hundreds of environmental chemicals are regularly detected in human tissues and fluids, little is known how these chemicals act and specifically how they act in combination. Here we show that EDC promote the adipogenic differentiation of mesenchymal stem cells (MSC) alone as well as in combination.

Methods: High or low concentrations of TBT (1nM; 100nM), DEHP $(100 \mathrm{nM} ; 100 \mu \mathrm{M})$, BPA $(10 \mathrm{nM}, 10 \mu \mathrm{M})$, or their mixtures at high $(\mathrm{MIX}+)$ or low (MIX-) concentrations, were used to expose MSC $\mathrm{C} 3 \mathrm{H} / 10 \mathrm{~T} 1 / 2$ at ontogenetically distinct stages of adipogenic development (proliferating stage, adipogenic induction and terminal differentiation). Adipogenic differentiation was analysed by determining the final amount of adipocytes and the mRNA expression of adipogenic marker genes. To investigate the mechanism of EDC-induced adipogenic differentiation, exposed cells were analysed for PPARg signalling by a PPAR-RE reporter gene assay.

Results: Exposure of $10 \mu \mathrm{M}$ BPA during the entire adipogenic differentiation led to a decreased development of adipocytes, whereas $100 \mu \mathrm{M}$ DEHP, 100nM TBT and MIX+ caused an increase. BPA exerted its effect only when cells were treated during proliferation, whereas DEHP acted during the induction period, and TBT exposure led to an increased amount of adipocytes in all three exposure intervals. Exposure to MIX+ also increased the adipogenic differentiation in all investigated stages, but to a lesser extent as TBT alone. In contrast, neither the exposure with low concentrations nor with MIX- had an effect on adipogenic differentiation. The transcription factor PPARg2 was identified as a functional target of DEHP and TBT.

Conclusions: Our findings indicate that BPA, DEHP and TBT affect the adipogenic differentiation of mesenchymal stem cells in a concentrateion-, stage-, compound- and combination- specific manner. We hypothesise that developmental or chronic lifetime exposure to EDC may contribute to the increasing prevalence of obesity.

Supported by DGKL, EU (FP7; REEF \#212885) and the Wilhelm Roux Programme of the MLU Facultyof Medicine, Halle 
P33 A GERMAN VERSION OF THE NIGHT EATING
QUESTIONNAIRE (NEQ): PREVALENCE AND
CORRELATES OF NIGHT EATING SYNDROME

Meule, A. ${ }^{1}$; Baumbusch, D. . ; Allison, K. ${ }^{2}$; Stunkard, A. ${ }^{2}$; Platte, P. ${ }^{1}$

${ }^{1}$ Department of Psychology I, University of Würzburg, Würzburg,

Germany; ${ }^{2}$ Department of Psychiatry, Center for Weight and Eating

Disorders, University of Pennsylvania, USA

Aims: Night eating syndrome (NES) is a pattern of eating behavior that involves evening hyperphagia or nocturnal ingestions, morning anorexia and insomnia. NES appears to be associated with obesity, but relationships with body-mass-index (BMI) have been inconsistent. Allison and colleagues (2008) developed the Night Eating Questionnaire (NEQ) for the assessment of severity of NES. Our aim was to provide a German version of the NEQ and investigate its psychometric properties as well as relationships with other eating behaviors, BMI, impulsivity, and circadian preference.

Methods: An online study was conducted in which participants provided sociodemographic and anthropometric data and completed the NEQ, the Mood Eating Scale, the Eating Disorder Examination Questionnaire, the Food Cravings Questionnaire, the short form of the Barratt Impulsiveness Scale, and the Morningness-Eveningness Questionnaire. A total of $N=729$ participants (age $M=23.55 \pm 3.89$ years; BMI $M=22.59 \pm$ $4.24 \mathrm{~kg} / \mathrm{m}^{2} ; 77.0 \%$ women, $\left.n=561\right)$ completed the entire study and $n=$ 305 participants completed a retest after three weeks.

Results: The four-factorial structure of the NEQ consisting of the subscales nocturnal ingestions, evening hyperphagia, morning anorexia and $\mathrm{mood} / \mathrm{sleep}$ could be replicated. Retest-reliability was $r=.77$ ( $p<$ $.001)$. Using the cut-off score of 25 (Allison et al., 2008), prevalence of NES was $1.2 \%$ for the total sample $(.9 \%$ in under-to-normal-weight $(n=$ $586)$ and $2.8 \%$ in overweight-to-obese $(n=143)$ participants). Small-tomedium positive correlations were found between scores on the NEQ and BMI, emotional eating, eating disorder psychopathology, general food cravings, impulsivity, and eveningness preference.

Conclusions: Psychometric properties of the original NEQ could be replicated. The prevalence of NES is increased in overweight and obese participants as compared to under- and normal-weight participants. Night eating is associated with other problematic eating behaviors, later circadian preference, and impulsivity. The German version of the NEQ appears to be a useful tool for future investigations on night eating.

\section{P34}

\section{FAT MASS AND OBESITY ASSOCIATED GENE (FTO) REGULIERT DIE EXPRESSION VON UCP-1 IN HUMANEN SGBS ADIPOZYTEN}

Tews, D. ${ }^{1}$; Fischer-Posovszky, . $^{1}$; Fromme, $T^{2}{ }^{2}$; Klingenspor, M. $^{2}$; Wabitsch, . $^{1}$

${ }^{1}$ Klinik für Kinder- und Jugendmedizin, Universitätsklinik Ulm, UIm, Deutschland; ${ }^{2}$ Else Kröner-Fresenius Zentrum Für Ernährungsmedizin, TU München, München, Deutschland

Fragestellung: Die Assoziation zwischen Varianten des FTO (fat mass and obesity associated) Gens und Adipositas-Parametern wurde in verschiedenen genomweiten Assoziationsstudien gezeigt. Das Gen codiert für eine 2-Oxoglutarat-abhängige Demethylase und wird ubiquitär exprimiert. FTO-defiziente Mausmodelle weisen auf eine Beteiligung von FTO der Regulation des Energiestoffwechsels hin. Seine Beteiligung am Stoffwechsel von Adipozyten wurde bisher allerdings nicht untersucht. In dieser Studie sollte die Rolle von FTO auf den Metabolismus von Adipozyten untersucht werden.

Methodik: Mittels lentiviral-vermittelter Expression von shRNA wurden FTO-defiziente SGBS Prä- und Adipozyten hergestellt. Die Expression von FTO und verschiedenen Markergenen wurde mittels qRT-PCR gemessen. Der relative Mitochondriengehalt wurde mittels MitroTracker Green Färbung und Messung der Citratsynthase-Aktivität bestimmt. Der zelluläre Sauerstoffverbrauch wurde mit einem Extracellular Flux Analyzer analysiert.

Ergebnisse: Wir erreichten sowohl bei SGBS Präadipozyten als auch in Adipozyten eine Transduktionseffizienz von $>90 \%$. Dies führte zu einer
Inhibition der FTO mRNA Expression um 73\% und einer nahezu vollständigen Repression auf Proteinebene. Interessanterweise war die Expression des uncoupling protein 1 (UCP-1) in FTO defizienten Adipozyten ca. 4-fach höher als in Kontrollzellen. Der Gehalt von Mitochondrien war dabei unverändert. Die höhere UCP-1 Expression ging mit einer verstärkten Entkopplung der mitochondrialen Atmung einher. Schlussfolgerung: Unsere Untersuchungen zeigen, dass FTO die Expression von UCP-1 reguliert. Möglichweise agiert FTO als molekularer Schalter an der Schnittstelle zwischen weißer und brauner Fettzelldifferenzierung. Detaillierte Untersuchungen der Signalwege, die FTO mit der Entwicklung brauner Adipozyten im weißen Fettgewebe verbindet könnte zu neuen Strategien zur Bekämpfung von Adipositas führen.

Dieses Projekt wurde durch das Bundesministerium für Bildung und Forschung (NGFNplus, FKZ 01GS0824) gefördert.

\section{Adipositas und Komorbidität / Körperzusammensetzung und Diagnostik}

\section{P41}

\section{PHLEBOCHIRURGISCHE ELEKTIVEINGRIFFE BEI PATIENTEN MIT ADIPOSITAS}

Vogt, . $^{1}$; Bader, C. ${ }^{1}$; Broermann, M. $^{1}$

${ }^{1}$ Artemed Fachklinik München, München, Deutschland

Fragestellung: Ein wesentlicher Anteil der Patienten, die sich einem phlebochirurgischen Eingriff stationär unterziehen, leidet einerseits an einer massiv ausgeprägten Stammvarikosis oder Rezidivvarikosis mit Zeichen einer fortgeschrittenen chronisch-venösen Insuffizienz mit manifesten Haut- und Gewebeveränderungen und andererseits an einer Adipositas Grad I, II oder III mit adipositasassoziierten Komorbiditäten. Die prädiktive Bedeutung des Risikofaktors Adipositas für das klinische Outcome in der Varizenchirurgie soll analysiert werden.

Methodik: In einer monozentrischen retrospektiven klinischen Studie wurden über einen Zeitraum von 12 Monaten Patienten mit phlebochirurgischen Eingriffen aufgrund einer Vena saphena magna- oder parvaInsuffizienz sowie aufgrund inguinaler oder poplitealer Krossenrezidive eingeschlossen. Die Häufigkeit der Adipositas Grad I, II und III in diesem Patientenkollektiv wurde ermittelt; präoperativ erfolgte eine individuelle Risikoabschätzung unter Beachtung der adipositasassoziierten Komorbiditäten. Erfasst wurden perioperative Minor-Komplikationen, wie z.B. konservativ behandelbare unkomplizierte Blutungskomplikationen (flächenhafte Hämatome, disseminierte Hämatome), Wundheilungsstörungen oder Wundinfektionen, sowie perioperative Major-Komplikationen, wie z.B. großvaskuläre Blutungskomplikationen oder tiefe Beinvenenthrombosen.

Ergebnisse: Im Beobachtungszeitraum erfolgten 3751 phlebochirurgische Eingriffe entsprechend der Einschlusskriterien unter stationären Bedingungen. Die Häufigkeit der Adipositas im Patientenkollektiv betrug 34,3\% (1286/3751), der Adipositas Grad I 27,7\% (1039/3751), der Adipositas Grad II 4,2\% (156/3751) und der Adipositas Grad III 2,4\% (91/3751). Unter Beachtung der adipositasassoziierten Komorbiditäten sowie unter individueller Anpassung des operativen Procedere und der postoperativen stationären Behandlung unterschied sich die Minor-Komplikationsrate der Patienten mit Adipositas nicht von derjenigen nicht-adipöser Patienten. Major-Komplikationen wurden nicht beobachtet.

Schlussfolgerung: Adipositas Grad I, II oder III ist per se nicht mit einem erhöhten perioperativen Risiko assoziiert. Eine individuelle Beurteilung des Operationsrisikos unter Beachtung von Art und Dauer der geplanten Operation und eine Identifizierung der adipositasassoziierten Komorbiditäten ist zum Erreichen eines optimalen kurz- und langfristigen Operationsergebnisses bei Patienten mit Adipositas von zentraler Bedeutung. 


\section{P42}

\section{EFFEKTIVE BLUTDRUCKSENKUNG DURCH AMBULANTES ERNÄHRUNGSKONZEPT}

Becker, C. ${ }^{1}$; Walle, H. $^{1}$

${ }^{1}$ Bodymed AG, Kirkel, Deutschland

Fragestellung: Kann mit einem ambulanten Ernährungskonzept, das primär auf den Gewichtsverlust abzielt, eine effektive Senkung des Blutdrucks (systolisch, diastolisch) erzielt werden?

Methodik: Entsprechend des Vorliegens von Bluthochdruck zu Programmbeginn, wurde die Gesamtgruppe $(n=392)$ in 1. Hypertoniker mi antihypertensiver Behandlung $(\mathrm{n}=102), 2$. Hypertoniker ohne antihypertensive Behandlung $(n=77)$ und 3. Normotoniker $(n=213)$ differenziert Neben Gewichtsabnahme wurden die Veränderungen des Blutdrucks (systolisch, diastolisch) innerhalb eines Jahres beobachtet. Die Auswertung erfolgte als ITT-Analyse. Angegeben werden Mittelwert \pm Standardabweichung.

Ergebnisse: Zu Programmbeginn wurden höchste Werte bei Körpergewicht (KG: 104,6 $\pm 18,4 \mathrm{~kg}$ ) und Blutdruck (systolisch: 155,4 $\pm 12,2$ mmHg, diastolisch: $88,1 \pm 8,1 \mathrm{mmHg}$ ) sowie deutlichste mittlere $\mathrm{Ab}$ nahmen innerhalb eines Jahres $(12,4 \mathrm{~kg}, 28,0 \mathrm{mmHg}, 9,6 \mathrm{mmHg})$ in Gruppe 2 erkannt, $\mathrm{P} £ 0,001$. Niedrigste Werte und geringste (dennoch deutliche und hochsignifikante) Abnahmen bestanden bei Normotonikern (Gruppe 3, mittlere Abnahme KG: 9,3 kg [von 95,8 $\pm 16,9$ auf 86,5 $\pm 15,6 \mathrm{~kg}$ ], Blutdruck: systolisch: $6,1 \mathrm{mmHg}$ [von 127,3 $\pm 10,2$ auf $121,2 \pm 11,8 \mathrm{mmHg}$ ], diastolisch: 4,1 $\mathrm{mmHg}$ [von 79,3 $\pm 6,2$ auf 75,2 \pm 9,1 mmHg], P $£$ 0,001). Hypertoniker, die bereits Antihypertensiva erhielten (Gruppe 1), erzielten einen KG-Verlust von im Mittel 10,5 kg (von 101,8 $\pm 18,2$ auf 91,3 $\pm 16,9 \mathrm{~kg}$ ) sowie eine zusätzliche Blutdrucksenkung um im Mittel 17,9 mmHg (systolisch, von 145,3 $\pm 16,5$ auf $127,4 \pm 14,6 \mathrm{mmHg}$ ) und 7,5 $\mathrm{mmHg}$ (diastolisch, von 86,1 $\pm 8,8$ auf $78,6 \pm 8,7 \mathrm{mmHg}), \mathrm{P} £ 0,001$. Nach einem Jahr wiesen alle Gruppen mittlere Blutdruckwerte (systolisch/diastolisch) auf, die sich im Normbereich $(<130 / 80 \mathrm{mmHg})$ befanden. Diese Verbesserungen spiegelten sich auch in der veränderten Gruppenzugehörigkeit wider. 1 Jahr nach Programmbeginn gehörten nur noch 84 Teilnehmer (TN) der Gruppe 1 (Abnahme um 17,7\%), 26 TN der Gruppe 2 (Abnahme um 66,2\%), dafür 282 TN der Gruppe 3 (Normotoniker, Zunahme um 32,4 \%) an.

Schlussfolgerung: In allen betrachteten Gruppen wurde mit dem vorgestellten ambulanten Ernährungskonzept innerhalb eines Jahres nicht nur eine deutliche Gewichtsabnahme, sondern darüber hinaus eine effektive Senkung der Blutdruckwerte (systolisch, diastolisch) erzielt. Bei gut 1/3 der TN, bei denen zu Programmbeginn Hypertonie bestand, wurden die erhöhten Blutdruckwerte normalisiert.

Dr. Hardy Walle ist Gründer und Vorstand der Bodymed AG, die Anbieter des vorgestellten Ernährungskonzepts ist. Dr. Christine Becker ist in der medizinischwissenschaftlichen Abteilung der Bodymed AG angestellt.

\section{P43}

\section{LUNGENFUNKTION UND KARDIOPULMONALE FITNESS BEI EXTREM ADIPÖSEN FRAUEN MIT UND OHNE INSULINRESISTENZ}

Wilms, B. ${ }^{1}$; Ernst, B. ${ }^{1}$; Zazai, R. ${ }^{1}$; Waldburger, R. ${ }^{1}$; Weisser, B. ${ }^{2}$; Schultes, $B^{1}$

${ }^{1}$ Interdisziplinäres Adipositas-Zentrum, Kantonsspital St. Gallen,

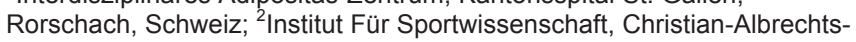
Universität zu Kiel, Kiel, Deutschland

Fragestellung: Neben einer niedrigen kardiopulmonalen Fitness stellt auch eine reduzierte Lungenfunktion einen unabhängigen Risikofaktor für eine frühzeitige Mortalität dar. Erste Daten belegen, dass nicht nur bei Typ 2 Diabetes Mellitus (T2DM) sondern auch schon bei Insulinresistenz (IR) die Lungenfunktion beeinträchtig ist. Daher sollten die Zusammenhänge zwischen Parametern des Glukosestoffwechsels, der Lungenfunktion sowie kardiopulmonalen Fitness bei adipösen Frauen $\left(\mathrm{BMI}>35 \mathrm{~kg} / \mathrm{m}^{2}\right)$ ohne T2DM untersucht werden.

Methode: In diese Querschnittstudie wurden 127 Nichtraucherinnen (BMI: 44,3 $\pm 5,3 \mathrm{~kg} / \mathrm{m}^{2}$ ) eingeschlossen. Der 1-Sekundenwert (FEV1) sowie die inspiratorische Vitalkapazität (CVin) wurden mittels Spirometrie erfasst. Die Fitness, d.h. $\mathrm{O}_{2}$-Aufnahme und Leistung bei Belas- tungsende $\left(\mathrm{VO}_{2}\right.$-peak, Watt-peak) wurde mittels Fahrradergospirometrie bestimmt. Glukose- und Insulinwerte lagen für alle Frauen vor, HbAlcWerte für 96. Anhand des HOMA-Index wurde die Gruppe in Frauen mit (Homa $\geq 3,8 ; n=34)$ und ohne (Homa $<3,8 ; n=93)$ IR differenziert.

Ergebnisse: Beide Gruppen waren in Alter und Größe gut vergleichbar (beide $\mathrm{p}>0,69$ ). Der BMI lag bei Frauen mit IR bei $45,3 \pm 6,1 \mathrm{~kg} / \mathrm{m}^{2}$, bei Frauen ohne IR bei $43,9 \pm 5,0 \mathrm{~kg} / \mathrm{m}^{2}(\mathrm{p}=0,18)$. Erwartungsgemäß hatten Frauen mit IR höhere Glukose-, Insulin- und HbAlc-Werte (alle $\mathrm{p}<0,014$ ). Die absoluten und relativen (in Bezug auf Richtwerte) FEV1und CVin-Werte sowie der FEV1/CVin-Ratio unterschieden sich jedoch nicht (alle $\mathrm{p}>0,11$ ). Auch bestanden keine Unterschiede in den absoluten $\mathrm{VO}_{2}$-peak- und Watt-peak-Werten sowie relativen (in Bezug zum Gewicht) $\mathrm{VO}_{2}$-peak/KG- und Watt-peak/KG-Werten (alle $\mathrm{p}>0,17$ ). Korrelationsanalysen ergaben jedoch inverse Beziehungen von HbA1c mit FEV1, CVin, Watt-peak sowie Watt-peak/KG (alle $r>-0,23$; alle $\mathrm{p} £ 0,02)$. Insulin korrelierte mit dem FEV1/CVin-Ratio $(\mathrm{r}=0,18$; $\mathrm{p}=0,04)$. Multiple lineare Regressionsanalysen bestätigten, dass sowohl HbA1c als auch Insulin unabhängig von Alter, Größe und, im Fall von Insulin, Gewicht Determinanten von Watt-peak/KG $(\mathrm{p}=0,02$; beta $=$ 0,$\left.24 ; \mathrm{R}^{2}=5,6 \%\right)$ bzw. vom FEV1/CVin-Ratio $(\mathrm{p}=0,04 ;$ beta $=0,19$; $\left.\mathrm{R}^{2}=3,5\right)$ waren.

Schlussfolgerung: Es konnte nicht gezeigt werden, dass adipöse Frauen mit IR eine eingeschränkte Lungenfunktion und Fitness im Vergleich zu Frauen ohne IR haben. Allerdings gibt es erste Hinweise, dass Parameter des Glukosestoffwechsels, insbesondere HbA1c, mit der Fitness als auch der Lungenfunktion, bereits bevor sich eine T2DM-Erkrankung manifestiert hat, assoziiert sind.

P44

\section{EINFLUSS VON BMI UND BMI-VERÄNDERUNG AUF ZUKÜNFTIGE ARZNEIMITTELAUSGABEN BEI ERWACHSENEN: ERGEBNISSE DER MONICA/KORA KOHORTENSTUDIE (KOMPETENZNETZ ADIPOSITAS)}

Wenig, C.M. ${ }^{1}$; Menn, P. ${ }^{2}$; Heier, M. ${ }^{3}$; Holle, R. ${ }^{2}$; John, J. ${ }^{2}$; Wolfenstetter, S.B.2

${ }^{1}$ Ludwig-Maximilians-Universität München, Institut für Gesundheitsökonomie und Management im Gesundheitswesen, München, Deutschland; ${ }^{2}$ Helmholtz Zentrum München, Deutsches Forschungszentrum für Gesundheit und Umwelt, Institut für Gesundheitsökonomie und Management im Gesundheitswesen, München, Deutschland; ${ }^{3}$ Helmholtz Zentrum München, Deutsches Forschungszentrum für Gesundheit und Umwelt, Institut für Epidemiologie II, München, Deutschland

Fragestellung: Mit steigenden Prävalenzraten stellt Adipositas heute ein schwerwiegendes Gesundheitsproblem in unserer Gesellschaft dar, das auch ökonomische Implikationen, unter anderem in Form von höheren Gesundheitsausgaben, mit sich bringt. Bisher gibt es wenig verfügbare Evidenz zu den langfristigen ökonomischen Effekten von Adipositas. Ziel dieser Studie ist es, den Zusammenhang zwischen Body Mass Index (BMI) und BMI-Veränderung mit der künftigen Inanspruchnahme von Arzneimitteln und den dadurch entstehenden Ausgaben zu untersuchen.

Methodik: Basierend auf den Daten von 2962 Teilnehmern eines bevölkerungsbasierten Gesundheitssurveys in Deutschland (MONICA/KORA, 1994/95) und seiner Folgestudie (2004/05) wurde die Einnahme von Arzneimitteln erhoben und die damit zusammenhängenden Ausgaben mittels Bottom-Up Ansatzes geschätzt. Mit Hilfe generalisierter linearer Regressionsmodelle wurden Arzneimitteleinnahme und kosten nach 10 Jahren zwischen unterschiedlichen Baseline-BMIGruppen verglichen. Außerdem wurde der Einfluss der BMIVeränderung innerhalb der 10-Jahres-Periode untersucht.

Ergebnisse: Nach Adjustierung für Alter, Geschlecht und sozioökonomischen Status zeigte sich, dass moderat $(\mathrm{OR}=1,8)$ und schwer adipöse Menschen $(\mathrm{OR}=4,0)$ verglichen mit normalgewichtigen Teilnehmern häufiger Arzneimittel einnahmen. Unter den Teilnehmern, die Arzneimittel einnahmen, waren die Ausgaben für die adipöse Gruppe um 40\% erhöht. Höhere Arzneimittelausgaben waren besonders für diejenigen Arzneimittelgruppen erkennbar, die die Bereiche „Alimentäres System und Stoffwechsel“ (ATC-Gruppe A) sowie „Cardiovasculä- 
res System" (ATC-Gruppe C) betrafen. Eine Zunahme um einen BMIPunkt in 10 Jahren war mit signifikant höheren Ausgaben im Vergleich zu den Teilnehmern mit konstantem BMI verbunden.

Schlussfolgerung: Dies ist die erste deutsche Studie, die längerfristige Effekte von Adipositas sowie Gewichtsveränderung auf die Arzneimittelausgaben in einem Bottom-Up Ansatz analysiert. Die Ergebnisse deuten darauf hin, dass Adipositas sowie ein Gewichtsanstieg starke Prädiktoren für künftige Arzneimittelausgaben bei Erwachsenen darstellen. Dies unterstreicht die Notwendigkeit frühzeitiger und effektiver Interventions- und Präventionsprogramme. Die vorliegende Studie ergänzt die bereits existierende Literatur zur Relevanz von Adipositas aus gesellschaftlicher Perspektive.

\section{P45 \\ MESSUNG DES RUHEENERGIEVERBRAUCHS MITTELS SENSEWEAR ARMBAND BEI ADIPÖSEN ERWACHSENEN: KEINE ALTERNATIVE ZUR INDIREKTEN KALORIMETRIE}

Waldburger, R. ${ }^{1}$; Zazai, R. ${ }^{1}$; Ernst, B. ${ }^{1}$; Wilms, B. ${ }^{1}$; Schultes, B. ${ }^{1}$

${ }^{1}$ Interdisziplinäres Adipositas Zentrum, Kantonsspital St. Gallen,

Rorschach, Schweiz

Einleitung: Das Sensewear Armband (SWA) wird in der klinischen Praxis aber auch in Studien immer häufiger zur Erfassung der körperlichen Aktivität sowie des Aktivitätsenergieumsatzes eingesetzt. Basis fü die Erfassung des Energieumsatzes ist die Messung des Ruheenergieverbrauchs (REE). Vorausgehende Studien haben jedoch Zweifel daran geweckt, dass das SWA zuverlässig den REE von adipösen Menschen messen kann. Vor diesem Hintergrund wird der mittels SWA gemessene REE mit dem mittels indirekter Kalorimetrie (IC) gemessenen REE verglichen.

Methodik: Insgesamt wurden 188 adipöse Frauen (BMI: 41,4 $\pm 6,1$ $\mathrm{kg} / \mathrm{m}^{2}$, Alter: 41,2 $\pm 12,7$ Jahre) und 76 adipöse Männer (BMI: 43,9 $\pm 6,5$ $\mathrm{kg} / \mathrm{m}^{2}$, Alter: $44,7 \pm 12,5$ Jahre) untersucht. Der REE wurde über 20 Minuten mittels IC und parallel mittels des SWA gemessen. Die Überprüfung der Übereinstimmung beider Methoden erfolgte mittels Bland Altman Analyse. Eine Abweichung des REE-SWA vom REE-IC von mehr als 10\% wurde als Unter- oder Überschätzung klassifiziert.

Resultate: Die Bland Altman Analyse ergab über beide Geschlechter zusammen betrachtet $(\mathrm{r}=-0,219, \mathrm{p}<0,001)$ sowie für die Frauen $(\mathrm{r}=$ $-0,537, \mathrm{p}<0,001)$ eine inverse Korrelation. Demzufolge ist die Übereinstimmung der beiden Messmethoden abhängig vom individuellen REE je höher resp. je tiefer der REE-IC ist, desto höher die Differenz zwischen REE-IC und REE-SWA. Interessanterweise lag bei den Männern $(r=-0,113, p=0,333)$ keine systematische Abweichung vor. Bei 29,8\% der Frauen unterschätzte das SWA den REE um 10,0-19,9\%, bei 3,7\% um 20,0-29,9\% und bei 1,6\% lag eine Unterschätzung von mindestens $30 \%$ vor. Eine Überschätzung des REE durch das SWA um 10,0-19,9\% wurde bei $20,2 \%$ der Frauen festgestellt, eine Überschätzung um 20,0$29,9 \%$ bei 12,8\% der Frauen und um mindestens 30\% noch bei 4,3\% des weiblichen Kollektivs. Bei 15,8\% der Männer unterschätzte das SWA den REE um 10,0-19,9\% und bei 2,6\% der Männer um mindestens $20 \%$. Eine Überschätzung des REE durch das SWA um 10,0-19,9\% wurde bei 15,8\% der Männer festgestellt, eine Überschätzung von 20,0 $29,9 \%$ bei $6,6 \%$ der Männer.

Schlussfolgerung: Unsere Daten zeigen, dass das SWA nur in 55,3\% der Frauen und Männer den REE (gemessen mittels IC) mit einer ausreichenden Genauigkeit (Abweichung max. +/-10\%) messen kann. Das SWA stellt somit kein geeignetes Gerät dar, um den REE bei adipösen Erwachsenen zuverlässig zu messen.
P46

\section{REFERENZBEREICHE FÜR DIE KARDIOPULMONALE LEISTUNGSFÄHIGKEIT VON MÄNNERN MIT AUSGEPRÄGTER ADIPOSITAS}

Wilms, B. ${ }^{1}$; Ernst, B. ${ }^{1}$; Waldburger, R. ${ }^{1}$; Zazai, R. ${ }^{1}$; Weisser, B. ${ }^{2}$; Schultes, $B{ }^{1}$

${ }^{1}$ Interdisziplinäres Adipositas-Zentrum, Kantonsspital St. Gallen Rorschach, Schweiz; ${ }^{2}$ Institut für Sportwissenschaft, Christian-AlbrechtsUniversität zu Kiel, Kiel, Deutschland

Fragestellung: Für normalgewichtige Frauen und Männer liegt eine Vielzahl an Richtwerten für die kardiopulmonale Leistungsfähigkeit vor, deren Berechnungen sich hauptsächlich auf die Parameter Körpergewicht- und größe sowie Alter gründen. Für schwer adipöse Männer sind hingegen kaum Referenzwerte bzw. Prädiktionsformeln publiziert. Daher sollte die Möglichkeit der Entwicklung einer Adipositasspezifischen Prädiktionsformel für die Leistungsfähigkeit von Männern mit Adipositas Grad II oder höher geprüft werden.

Methodik: Bei 179 Männer im Alter von 18 bis 68 Jahren und einem BMI von 45,5 $\pm 6,2 \mathrm{~kg} / \mathrm{m}^{2}$ (Spannweite: $35,0-65,1 \mathrm{~kg} / \mathrm{m}^{2}$ ) wurde die kardiopulmonale Leistungsfähigkeit (= höchste $\mathrm{O}_{2}$-Aufnahme sowie Leistung bei Belastungsende, $\mathrm{VO}_{2}$-peak, Watt-peak) mittels FahrradErgospirometrie bestimmt. Unabhängige Prädiktoren der kardiopulmonalen Leistungsfähigkeit wurden mittels schrittweiser, multivariater linearer Regressionsanalysen ermittelt.

Ergebnisse: Bei Belastungsende wurde im Mittel ein $\mathrm{VO}_{2}$-peak Wert von 2,30 $\pm 0,601 / \mathrm{min}$ bei einem respiratorischen Quotienten (RQ-peak) von $1,10 \pm 0,09$ erreicht. Die mittlere $\mathrm{VO}_{2}$-peak bezogen auf das Körpergewicht $\left(\mathrm{VO}_{2}\right.$-peak/KG) lag bei $16,6 \pm 4,5 \mathrm{ml} / \mathrm{kg}^{*} \mathrm{~min}^{-1}$. Watt-peak lag bei $160 \pm 45 \mathrm{~W}$, relativ zum Körpergewicht (Watt-peak/KG) bei $1,16 \pm 0,35 \mathrm{~W} / \mathrm{kg}$. Die Größe erklärte allein $17,1 \%$ der Varianz der $\mathrm{VO}_{2}-$ peak (Beta: 0,35; $\mathrm{p}<0,001$ ), das Alter weitere 8,3\% (Beta: $-0,30$; $\mathrm{p}<0,001)$. Das Gewicht war hingegen nicht signifikant mit der Leistungsfähigkeit assoziiert $(\mathrm{p}=0,65)$. Da auf Basis dieser geringen Varianzaufklärung keine Prädiktionsformel generiert werden könnte, wurden adipositas-spezifische Referenzbereiche für vier Gruppen, definiert durch den Median von Größe $(<176 ; \geq 176 \mathrm{~cm})$ und Alter $(<46 ; \geq 46$ Jahre), berechnet. Die für die Referenzbereiche definierten Zielvariablen $\mathrm{VO}_{2}$-peak, $\mathrm{VO}_{2}$-peak/KG, Watt-peak und Watt-peak/KG unterschieden sich jeweils zwischen den Gruppen (alle $p<0,001$ ), während die Intensität bei Belastungsende, definiert über RQ-peak und prozentuale maximale Herzfrequenz, gut vergleichbar war (beide $\mathrm{p}>0,51$ ).

Schlussfolgerung: Lediglich $25 \%$ der Varianz der kardiopulmonalen Leistungsfähigkeit konnten durch Größe und Alter erklärt werden, so dass auf eine Formelentwicklung verzichtet wurde. Die Beurteilung der Leistungsfähigkeit von Männern mit ausgeprägter Adipositas sollte daher vorzugsweise anhand von größen- und altersspezifischen Referenzbereichen erfolgen. Unsere Studie bietet hierzu erstmals entsprechende Daten.

\section{Adipositas und Psyche / Prävention \\ P53 \\ LANGFRISTIGE VERBESSERUNGEN DER \\ LEBENSQUALITÄT ZWEI JAHRE NACH EINER STATIONÄREN ADIPOSITASTHERAPIE BEI KINDERN UND JUGENDLICHEN}

Rank, M. ${ }^{1}$; Wilks, D. ${ }^{1}$; Foley, L. $^{2}$; Langhof, H. $^{3}$; Siegrist, M. ${ }^{1}$; Halle, $M^{1}$

${ }^{1}$ Präventive und Rehabilitative Sportmedizin, Klinikum Rechts der Isar, TU München, München, Deutschland; ${ }^{2}$ Clinical Trials Research Unit, University of Auckland, New Zealand; ${ }^{3}$ Klinik Schönsicht, Berchtesgaden, Deutschland

Fragestellung: Adipositas im Kindesalter ist mit einer reduzierten Lebensqualität assoziiert. Ziel dieser Studie war es, langfristige Veränderungen der Lebensqualität von Kindern und Jugendlicher nach einer stationären Adipositastherapie zu untersuchen. 
Methodik: Zu Beginn einer 4-6 wöchigen stationären Adipositastherapie wurden 717 übergewichtige und adipöse Kinder und Jugendliche (409 Mädchen) im Alter von 13,9 $\pm 2,3$ Jahren in die Studie eingeschlossen. Körpergröße und -gewicht wurden vor und nach der Therapie in der Klinik und zwei Jahre nach Therapiebeginn beim betreuenden Kinderoder Hausarzt gemessen. Zu allen Zeitpunkten wurden Fragebögen zur Lebensqualität (KINDL) ausgefüllt. Von 305 Kindern (185 Mädchen) lagen Fragebögen zwei Jahre nach Therapiebeginn vor. Die Subskalen der sechs Dimensionen des KINDL-Fragebogens („Körperliches Wohlbefinden“, „Psychisches Wohlbefinden“, „Selbstwert", „Freunde“, „Familie“, „Schule“) wurden zu einem Gesamtscore kombiniert. Alle Skalen wurden in Werte von 0-100 transformiert, wobei höhere Werte eine bessere Lebensqualität anzeigen.

Ergebnisse: Die Lebensqualität (Gesamtscore) verbesserte sich im Therapieverlauf von $65,9 \pm 12,4$ auf $70,8 \pm 10,9$ Punkte und lag zwei Jahre nach Therapiebeginn mit 68,6 $\pm 13,8$ Punkten über dem Ausgangsniveau (beide $\mathrm{p}<0,001)$. Dies spiegelte sich in einer Verbesserung von Therapiebeginn bis zwei Jahre danach in den Dimensionen „Selbstwert“ $(47,1 \pm 21,7$ auf 57,2 $\pm 22,0$ Punkte; $p<0,001)$ und ,psychisches Wohlbefinden" (73,0 019,3 auf 75,6 $\pm 17,7$ Punkte; $p=0,001)$ wider. Bei der Dimension „Familie” zeigte sich ein Rückgang von $81,1 \pm 18,7$ Punkten zu Therapiebeginn auf 76,5 $\pm 21,0$ Punkte zwei Jahre danach $(\mathrm{p}<0,001)$. Der Body Mass Index (BMI) bzw. der BMI-SDS reduzierten sich im Therapieverlauf von $33,6 \pm 6,1 \mathrm{~kg} / \mathrm{m}^{2}$ auf $29,7 \pm 5,5 \mathrm{~kg} / \mathrm{m}^{2}$ bzw. $2,7 \pm 0,6$ auf 2,3 $\pm 0,6$ (beide $\mathrm{p}<0,001$ ). Zwei Jahre nach Therapiebeginn lagen die Mittelwerte mit $32,0 \pm 6,3 \mathrm{~kg} / \mathrm{m}^{2}(\mathrm{p}=0,015) \quad$ bzw. $2,4 \pm 0,8 \quad(\mathrm{p}<0,001)$ immer noch unter dem Ausgangsniveau.

Schlussfolgerung: Die Lebensqualität übergewichtiger und adipöser Kinder und Jugendlicher kann nach einer stationären Adipositastherapie langfristig verbessert werden, was sich besonders in einer Steigerung des Selbstwerts und des psychischen Wohlbefindens widerspiegelt.

\section{P54}

\section{AUFBAU EINES PSYCHOSOZIALEN REGISTERS DER ADIPOSITASCHIRURGIE}

\section{Baldofski, S. ${ }^{1}$; Rudolph, A. ${ }^{1}$; Till, H. $^{1}$; Hilbert, A. $^{1}$ \\ ${ }^{1}$ Universitätsmedizin Leipzig, Leipzig, Deutschland}

Fragestellung: Nach adipositaschirurgischen Eingriffen zeigt ein substantieller Anteil von Patienten keinen oder einen nur unzureichenden Gewichtsverlust sowie eine langfristige Gewichtswiederzunahme. Obwohl bislang keine robusten Prädiktoren für den Behandlungserfolg identifiziert wurden, gibt es Hinweise, dass Adipositaschirurgie das Essverhalten und die psychosoziale Anpassung wesentlich beeinflusst und dass diese Faktoren relevant für die postoperative Gewichtskontrolle sind. Der Aufbau eines nationalen, multizentrischen Registers zur längsschnittlichen Erfassung psychosozialer Faktoren in der Adipositaschirurgie (,PRAC - Psychosoziales Register der Adipositaschirurgie“) soll dazu beitragen, Zusammenhänge zwischen diesen Faktoren und ihre Bedeutung für die Vorhersage des Behandlungserfolgs zu bestimmen.

Methodik: In einer konsekutiven Stichprobe erwachsener und jugendlicher Patienten werden psychosoziale Aspekte umfassend dokumentiert Zur Anwendung kommen state-of-the-art psychometrische Instrumente zur Erfassung der allgemeinen Psychopathologie, gewichtsbezogenen Lebensqualität, des Essverhaltens sowie weiterer psychosozialer Variablen. Ein strukturiertes Experteninterview zur spezifischen Essstörungspsychopathologie bei bariatrischen Patienten (,Eating Disorder Examination Bariatric Surgery Version“) wird durchgeführt. Die Erhebung erfolgt vor dem bariatrischen Eingriff, sechs Monate sowie anschließend einmal jährlich nach Operation.

Ergebnisse: Die bisher eingeschlossenen präbariatrischen Patienten zwischen 27 und 65 Jahren (MW = 46,6 Jahre; SD = 11,04) hatten einen durchschnittlichen Body Mass Index von 47,25 kg/m ${ }^{2}$ (SD = 7,36 $\mathrm{kg} / \mathrm{m}^{2}$ ). Erste Auswertungen zeigen eine geringere Lebensqualität im Vergleich mit nicht-behandlungssuchenden adipösen Personen sowie Emotionsregulationsschwierigkeiten und ein erhöhtes Stigmatisierungserleben. In Bezug auf die Essstörungspsychopathologie ergaben sich mit essgestörten Patienten vergleichbare Werte. Zudem zeigte sich eine erhöhte Tendenz für hedonisches Essen. Die Diagnose einer Food Addiction erhielten 33,3\% der Patienten.
Schlussfolgerung: Die Ergebnisse zeigen besonders in Bezug auf das Essverhalten Auffälligkeiten präbariatrischer Patienten. Es ist daher wichtig und Ziel dieses Registers, diese Faktoren auch nach der Operation $\mathrm{zu}$ evaluieren und ihren Zusammenhang zum postbariatrischen Gewichtsverlauf zu analysieren.

\section{P55 \\ DER ZUSAMMENHANG ZWISCHEN GEWICHTSVERÄNDERUNGEN UND GESUNDHEITSBEZOGENER LEBENSQUALITÄT: ERGEBNISSE AUS DER KORA S4/F4 KOHORTE}

Laxy, M. ${ }^{1}$; Hunger, M. ${ }^{1}$; Döring, A. ${ }^{2}$; Peters, A. ${ }^{2}$; Holle, R. ${ }^{1}$

${ }^{1}$ Institut für Gesundheitsökonomie und Management im

Gesundheitswesen, Helmholtz Zentrum München, München, Deutschland; ${ }^{2}$ Institut für Epidemiologie II, Helmholtz Zentrum München, München

Deutschland

Fragestellung: Trotz steigender Bedeutung der patientenbezogen Perspektive existiert nur eine sehr dünne wissenschaftliche Evidenz über den Zusammenhang zwischen Gewichtsveränderung und gesundheitsbezogener Lebensqualität (HRQL). Querschnittsstudien zeigen übereinstimmend, dass ein hoher Body-Mass-Index (BMI) mit geringer HRQL assoziiert ist. Repräsentative Längsschnittstudien liegen bisher hingegen kaum vor.

Methodik: Die Daten wurden im Rahmen der bevölkerungsbasierten KORA S4/F4 Kohortenstudie erhoben. Zwischen 1999 und 2001 wurden dabei 4261 Personen im Alter von 25 bis 74 untersucht; 3080 nahmen auch am 7 Jahre später stattfindenden Follow-Up teil. Körpergröße und -gewicht wurden standardisiert gemessen. Als HRQL-Instrument wurde der generische SF-12 Fragebogen eingesetzt. Basierend auf der prozentualen Veränderung des Körpergewichts wurden die Patienten getrennt nach Geschlecht in fünf Gruppen eingeteilt. Über lineare Regressionsmodelle wurde die mittlere Veränderung der HRQL-Scores in diesen Gruppen berechnet, jeweils adjustiert nach BMI bei Baseline, Alter und Komorbidität.

Ergebnisse: Querschnittsbetrachtungen zu Baseline zeigen, dass, ausgehend vom Normalgewicht, steigende BMI-Werte mit geringeren Werten in der körperlichen Summenskala des SF-12 (KSK) einhergehen. Der Score der psychischen Summenskala (PSK) hingegen zeigt keine derartige Assoziation. Im Längsschnitt führen Gewichtszunahmen bei Frauen in allen BMI-Kategorien zu einer Verschlechterung des PSK (von $-2,2$ bis $-3,7 ; \mathrm{p}<0,05$ ). Bei Männern tritt dieser Effekt nur bei bereits Adipösen auf $(-5,4 ; \mathrm{p}<0,05)$. Für die PSK wird ein differenzierteres Muster beobachtet. Insbesondere zeigt sich bei übergewichtigen und adipösen Frauen der Trend, dass eine zusätzliche Gewichtszunahme mit einem Anstieg in der PSK assoziiert ist.

Schlussfolgerung: Gewichtszunahme hat einen größeren Einfluss auf die gesundheitsbezogene Lebensqualität als Gewichtsabnahme. Sie führt zu einer Verschlechterung in der körperlichen Lebensqualität wobei das Ausmaß abhängig vom Ausgangsgewicht ist. Der Zusammenhang mit der psychischen Lebensqualität ist weniger eindeutig und unterscheidet sich von dem der körperlichen Skala. Die patientenbezogene Perspektive sollte in der Diskussion von Adipositas einen größeren Stellenwert einnehmen.

\section{P56}

ENTWICKLUNG UND IMPLEMENTATION EINER

SCHULBASIERTEN INTERVENTION ZUR ADIPOSITASPRÄVENTION BEI GRUNDSCHULKINDERN „KOMM MIT IN DAS GESUNDE BOOT - GRUNDSCHULE“

Wartha, O. ${ }^{1}$; Kobel, S. ${ }^{1}$; Kettner, S. ${ }^{1}$; Drenowatz, C. ${ }^{1}$; Schreiber, A. ${ }^{1}$; Wirt, T. ${ }^{1}$; Steinacker, J. ${ }^{1}$

${ }^{1}$ Universität UIm, UIm, Deutschland

Hintergrund und Fragestellung: Der stärkste Anstieg von Übergewicht und Adipositas im Kinder- und Jugendalter erfolgt in der Grundschulzeit, danach ist nur noch ein leichter Anstieg feststellbar (Kurth, Schaffrath, Rosario, 2010), deshalb stellt die Grundschule ein wichtiges Setting für Interventionsprogramme dar. Eine erfolgversprechende 
Methode für die theoriebasierte Interventionsentwicklung ist das sog. Intervention Mapping (IM) (Bartholomew, 2001), da es neben einer Bedarfsanalyse auch die Konzeption, Implementation und Evaluation anleitet.

Die Entwicklung und Implementierung des Präventionsprogramms „Komm mit in das gesunde Boot - Grundschule“ ermöglicht die Analyse folgender Fragestellungen:

Kann eine erfolgreiche schulbasierte Intervention mit Hilfe des IMAnsatzes entwickelt werden und welche Elemente beinhaltet sie?

Wird die Intervention von den Lehrern angenommen und eingesetzt?

Methodik: Die Entwicklung der Intervention wurde nach dem protokollbasierten IM-Ansatz durchgeführt, um eine theoriegeleitete Entwicklung und Implementation der Intervention zu erreichen werden fünf Arbeitsschritte durchlaufen.

Der Einsatz der Intervention und die Zufriedenheit der Lehrer wurden im Schuljahr 2010/2011 durch anonymisierte Fragebogen erfasst.

Ergebnisse: Ziele des lehrerzentrierten Interventionsansatzes sind „Förderung der Bewegung“, „Reduktion zuckerhaltiger Getränke“ und „Verringerung des Medienkonsum“. Für jede Klassenstufe gibt es Unterrichtseinheiten, Familien-Hausaufgaben, Bewegungsübungen und Materialien zur Elternarbeit. Die Lehrer werden von geschulten Multiplikatoren fortgebildet und betreut. Das Programm „Komm mit in das gesunde Boot - Grundschule“ wird seit dem Schuljahr 2009/10 in 427 Grundschulen in Baden-Württemberg durchgeführt.

Daten zur ersten Klassenstufe zeigen, dass Lehrer das Programm im Schuljahr 2010/2011 im Durchschnitt 17 Stunden unterrichteten. 84\% der Lehrer setzten die Bewegungskarteikarten mind. 1x/Woche ein. 96\% der Lehrer gaben an auch in Zukunft das Programm „Komm mit in das gesunde Boot" ganz bzw. teilweise einzusetzen.

Schlussfolgerung: Durch das Planungsmodell IM ist es gelungen eine umfangreiche und einsatzfähige Intervention zu entwickeln. Der Erfolg zeigt sich an der hohen Zahl teilnehmender Schulen, an den Implementationsraten und der großen Zufriedenheit mit den Materialien.

\section{P57 \\ PUBLIC ATTITUDES TOWARDS PREVENTION OF OBESITY}

Sikorski, C. ${ }^{1}$; Luppa, M. ${ }^{1}$; Schomerus, G. $^{2}$; Werner, $P^{3}$; König, H.-H. ${ }^{4}$;Riedel-Heller, S.G. ${ }^{1}$

${ }^{1}$ Institut für Sozialmedizin, Arbeitsmedizin und Public Health, Universität Leipzig, Leipzig, Deutschland; ${ }^{2}$ Klinik und Poliklinik für Psychiatrie und Psychotherapie, Universität Greifswald, Greifswald, Deutschland; ${ }^{3}$ Faculty of Social Welfare and Health Sciences, University of Haifa, Haifa, Israel;

${ }^{4}$ Institut für Medizinische Soziologie, Sozialmedizin und

Gesundheitsökonomie (IMSG), Universitätsklinikum Hamburg-Eppendorf, Hamburg, Deutschland

Objective: To investigate obesity prevention support in the German general public and to assess determinants of general prevention support as well as support of specific prevention measures.

Design: Cross-sectional analysis of a telephone based representative German study

Subjects: 3003 subjects $(52.8 \%$ women, mean age 51.9 , s.d. $=18.0$, range 18-97 years).

Measurements: Likert scale-based questions on general prevention support and support of specific measures; assessment of willingness to take part in preventive programs and willingness to pay; stigmatizing attitudes assessed with Fat Phobia Scale (FPS); and causation of obesity differentiated in three dimensions (internal, e.g. lack of exercise; external, e.g. social surroundings; and genetic factors).

Results: Obesity prevention was perceived as possible $(98.2 \%)$, however, almost exclusively lifestyle changes were named. Participants with higher stigmatizing attitudes were less likely to believe obesity prevention is possible. The majority of participants would take part in preventive programs $(59.6 \%)$ and pay at least partially themselves $(86.9 \%)$. Factor analysis revealed three dimensions of preventive measures: promoting healthy eating, restrictive and financial, governmental prevention efforts. In regard to these, promoting healthy eating was the most supported measure. Higher age, female gender and external causation were associated with higher support for all three dimensions of preventive measures. Only for governmental regulation, higher age was associated with lower support.

Conclusion: Obesity prevention support in Germany is high. Structural prevention efforts are supported by the majority of the general public in Germany. The vast majority proclaims willingness to pay themselves for programs of weight gain prevention. This could be an indication of higher perceived self-responsibility in the German system but also for risen "fear of fat" in the population due to media coverage. For Germany, the government and communities ought to be encouraged by these results to start the implementation of structural obesity prevention.

\section{P58}

\section{EFFEKTE EINES 30 WOCHEN}

\section{BEWEGUNGSPROGRAMMS AUF PHYSISCHE UND} PSYCHOSOZIALE RESSOURCEN, LEBENSQUALITÄT UND AKTIVITÄTSVERHALTEN BEI ÜBERGEWICHTIGEN KINDERN UND JUGENDLICHEN

\section{Wagner, . $^{1}$; Grützmacher, N. ${ }^{1}$; Müller, $K^{1}$}

${ }^{1}$ Universität Leipzig, Leipzig, Deutschland

Fragestellung: Regelmäßige körperlich-sportliche Aktivität gilt als Strategie zur Förderung von Gesundheit und Wohlbefinden in der Prävention und Therapie von Übergewicht und Adipositas. Bisher besteht jedoch ein Mangel an Untersuchungen zu den Effekten von Langzeitbewegungsnterventionen, die sich neben Risikofaktoren und Verhalten auch auf physische und psychosoziale Gesundheitsressourcen und Lebensqualität bei übergewichtigen und inaktiven Kindern beziehen (Summerbell et al., 2005). Mit der vorliegenden Studie werden solche Effekte eines 30 Wochen Bewegungs- und Verhaltensprogramms (Wagner, 2010) bei übergewichtigen und inaktiven Kindern im Sportverein überprüft.

Methodik: Von $11 / 2010$ bis $09 / 2011$ wurde eine Intervention mit 90 min Bewegungs- und Verhaltensschulung pro Woche und drei separaten Elternschulungen durchgeführt. Jede Einheit vereint Elemente zur Stärkung der physischen Ressourcen Ausdauer, Kraft, Beweglichkeit und Koordination sowie Techniken zum Barrieren- und Selbstmanagement. Die Stichprobe umfasst 8- bis 12-jährige Kinder ( $\mathrm{IG}$ : $\mathrm{n}=17, \mathrm{M}=10.5$ Jahre; KG: $n=17, M=10,0$ Jahre). Zu Beginn (t1), in der Mitte (t2) und am Ende (t3) der strukturierten Langzeitintervention wurden sowohl anthropometrische (z.B. BMI-SDS, Hautfaltendicke), motorische (KATS-K) und psychosoziale Parameter (z.B. Selbstwirksamkeit, soziale Unterstützung, KINDL) sowie Daten zur körperlichen Aktivität (HBSC-index) erhoben.

Ergebnisse: Erste Veränderungsanalysen für den Zeitraum t1 bis t3 zeigen für die IG vs. KG am Ende der Intervention signifikante Interaktionseffekte für die Lebensqualität $\left(\mathrm{F}=6,506 ; \mathrm{p}<0,05 ; \eta^{2}=0,19\right)$, die Selbstwirksamkeit $\left(\mathrm{F}=3,419 ; \mathrm{p}=0,076 ; \eta^{2}=0,12\right)$ sowie weitere physische und psychosoziale Ressourcen. Auch für ausgewählte Verhaltensaspekte (HBSC index: $F=5,439 ; p<0,05 ; \eta^{2}=0,16$ ) lassen sich signifikante Veränderungen im Vergleich zur Kontrollgruppe finden.

Schlussfolgerung: Die Befunde zeigen, dass mit dem Bewegungs- und Verhaltensprogramm physische und psychosoziale Ressourcen bei den übergewichtigen und inaktiven Kindern gestärkt werden und eine Implementierung z.B. im Sportverein anzustreben ist. Die positiven Effekte auf die Lebensqualität und die Selbstwirksamkeit der Kinder sowie die Steigerung der psychosozialen Schutzfaktoren stellen eine gute Voraussetzung für die Nachhaltigkeit der Verhaltensänderung dar. Im Laufe der Intervention haben die Kinder wahrgenommen, dass sie selbst etwas an ihrer Situation ändern können.

\section{Literatur:}

Summerbell, C., Waters, E., Edmunds, I., Kelly, S., Brown, T. \& Campbell, K.

(2005). Interventions for preventing obesity in children (Cochrane Review). Cochrane Database Systematic Review 3, CD001871.

Wagner, P. (2010). SafariKids - ein ressourcenorientiertes Bewegungsprogramm zur Prävention von Übergewicht bei Kindern. Bewegungstherapie und Gesundheitssport, 26, 52-57. 
P59

\section{HIGHER PREVALENCE OF ADIPOSITY AMONG CHILDREN AT AGE 11- COMPARED TO AGE 7 YEARS REFLECTS LOWER REMISSION RATES}

von Kries, R. ${ }^{1}$; Reulen, H. $^{1}$; Bayer, O. ${ }^{1}$; Riedel, C. $^{1}$; Diethelm, K. ${ }^{2}$; Buyken, A.E. ${ }^{2}$

${ }^{1}$ Institute of Social Paediatrics and Adolescent Medicine, Ludwig-

Maximilians-University, Munich, Germany; ${ }^{2}$ lel-Nutritional Epidemiology,

University of Bonn, Dortmund, Germany

Objective: To compare the age-specific balance between incidence and remission of excess body fat between age 3-7 and age 7-11 years.

Design: Prospective cohort study based on data from the DONALD Study, an ongoing open cohort study conducted in Dortmund, Germany Excess body fat was defined by the sum of triceps and subscapular skinfold measurements above the 90th reference percentile of the new German standard; overweight was defined by different national and international standards. The main outcome parameters were incidence and remission rates from $3 y$ to $7 y$ and from $7 y$ to $11 y$.

Results: The incidence rates of excess skinfold thickness between ages $7 \mathrm{y}$ to $11 \mathrm{y}(4.3(2.6,6.2) \%)$ and age 3 to $7 \mathrm{y}(4.2(2.4,6.2) \%)$ were almost identical. Remission rates in contrast were significantly lower during the age period of 7 to 11 years primary school age than in preschool age: $37.5(21.9,53.1 \%)$ compared to $72.3(59.6,85.1 \%)$ during the age period of 3 to 7 years

Conclusions: These data point to the low remission of excess body fat as an important driving force for the increasing prevalence of excess body fat in children aged 7 to 11 years. Public health initiatives in these children should encompass both primary prevention and interventions targeted at children already overweight at school entry.

\section{P60}

\section{PROMOTION OF PHYSICAL ACTIVITY IN ADOLESCENTS THROUGH USE OF A MULTIMEDIAL E-HEALTH PROGRAMME: STUDY CONCEPT}

Herget, S. $^{1}$; Wulff, H. $^{2}$; Grimm, A. ${ }^{1}$; Meigen, C. $^{3}$; Gausche, R. ${ }^{3}$; Blüher, $S^{1}$

${ }^{1}$ Integrated Research and Treatment Center (IFB) Adiposity Diseases, University of Leipzig, Leipzig, Germany; ${ }^{2}$ Institute of Exercise Science, Department of Rehabilitation and Public Health, University of Leipzig, Leipzig, Germany; ${ }^{3}$ Crescnet Ggmbh, Leipzig, Germany

Background: Physical inactivity considerably increases during adolescence, rendering young people at high risk for development of chronic diseases and obesity. Sedentary activities such as TV-viewing, webbased interactions via social media and mobile communication are increasingly pursued reducing daily time spent in active physical engagement. Effective prevention strategies are needed to increase moderate to vigorous physical activity levels of adolescents. The purpose of the proposed study concept is to describe the design, implementation and consequent feasibility analysis of an internet-based programme aimed at promoting increases in duration of physical activity (PA) in leisure time and every-day life in adolescence.

Methods and Design: A preliminary survey will be carried out to determine - besides sociodemographic factors - PA levels of secondary school students (aged 14 to 18 years) via self-report and accelerometer data, while stage of health behaviour change is assessed by the application of the Health Action Process Approach (HAPA) model.

After identification of the adolescent's HAPA stage, the feasibility of design and implementation of a 6-month stage-tailored intervention to increase duration of daily PA of the adolescents will be investigated. A one-year follow-up and a process evaluation will be carried out. Contents of the intervention comprise individual, tailored messages via the use of a website, which uses multimedia approaches including Elearning courses, Podcasts and serious games as a channel for information delivery on PA for adolescents. Exchange between participants and definition of participant goals are reinforced through an interactive internet forum and connection to virtual groups of social media platforms.
Discussion: More theory-based intervention strategies are needed to effectively promote physical activity in the daily life of adolescents. Approaching young people through the use of electronic media seems to be a reasonable and attractive strategy to reach this target group and needs further scientific exploration and evaluation.

\section{Konservative und chirurgische Therapie \\ P67 \\ BARIATRISCHE CHIRURGIE: AKTUELLE (MEDIZIN)ETHISCHE BEOBACHTUNGEN}

Ried, J. ${ }^{1}$

${ }^{1}$ Friedrich-Alexander-Universität Erlangen-Nürnberg, Erlangen, Deutschland

Aktuell ist eine doppelte Tendenz zur Ausweitung der bariatrischen Chirurgie zu beobachten: Zum einen gilt zunehmend auch eine niedergradige Adipositas, zumeist in Verbindung mit weitern Faktoren, als hinreichende Indikation für einen Eingriff. Zum anderen werden chirurgische Verfahren in steigendem Maße bei Kindern und Jugendlichen, insbesondere bei Vorliegen einer hochgradigen Adipositas, angewandt. Eine begleitende Diskussion zu den dabei zu Grunde gelegten Standards und den dadurch berührten (medizin)ethischen Fragen ist allerdings gerade erst im Entstehen begriffen. Die Untersuchung zielt darauf $a b$, die bislang diskutierten (medizinischen und ethischen) Maßstäben und Kriterien $\mathrm{zu}$ evaluieren und daraus Folgerungen für die zukünftige Praxis der bariatrischen Chirurgie abzuleiten.

Die einschlägige wissenschaftliche Literatur sowie entsprechende Dokumente zur Fixierung von Standards bzw. Leitlinien wurden gesichtet und im Hinblick auf die jeweils für entscheidungsrelevant erachteten medizinischen und ethischen Fragen ausgewertet.

Die Tendenz zur Ausweitung der bariatrischen Chirurgie wird sehr ambivalent beurteilt. Strittige Punkte sind vor allem die Nutzen-RisikoRelationen der Eingriffe, die Problematik der Nachbetreuung und die Beurteilung des Kriteriums, dass konservative Therapieoptionen ausgeschöpft sein sollen. Bei extrem adipösen Kindern und Jugendlichen sind insbesondere noch Fragen der informierten Zustimmung relevant. Insgesamt werden in Bezug auf die bariatrische Chirurgie in zunehmendem Maße auch eher allgemeinere Fragen nach der gesellschaftlichen Wahrnehmung und den sozialen Implikationen von Adipositas diskutiert. Bariatrische Chirurgie ist ein auch in der Öffentlichkeit vermehrt wahrgenommenes und debattiertes medizinisches Handlungsfeld mit bestimmten neuralgischen Punkten, die bislang weder ausreichend diskutiert noch in Leitlinien oder ähnlichen in der erforderlichen Tiefe reflektiert sind. Bisher erarbeitete Dokumente bieten aber teilweise eine gute Plattform, um mehr Kohärenz und Transparenz auf diesem Gebiet zu schaffen.

P68

\section{RUHEENERGIEVERBRAUCH EXTREM ADIPÖSER PATIENTEN EIN JAHR NACH MAGENBYPASS OPERATION}

\section{Wilms, B. ${ }^{1}$; Ernst, B. ${ }^{1}$; Thurnheer, M. ${ }^{1}$; Schultes, B. ${ }^{1}$}

${ }^{1}$ Interdisziplinäres Adipositas-Zentrum, Kantonsspital St. Gallen, Rorschach, Schweiz

Einleitung: Bariatrische Operationen stellen bislang die einzig effektive Massnahme zur langfristigen Gewichtsreduktion bei schwer adipösen Patienten dar. Ein häufig angewendetes Verfahren ist der Roux-Y Magenbypass (RYGB), dessen genaue Wirkmechanismen bislang jedoch nicht geklärt sind. Ein postoperativ erhöhter Ruheenergieverbrauch (REE) wird als einer der Wirkmechanismen postuliert. Wir untersuchten daher den REE von adipösen Patienten vor und ein Jahr nach einer RYGB Operation.

Methode: In einer Longitudinalstudie (I) wurde bei 175 adipösen Frau-

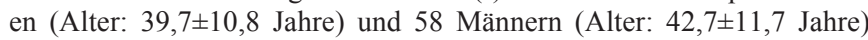
vor sowie ein Jahr nach RYGB der REE mittels indirekter Kalorimetrie bestimmt, die Körperzusammensetzung (fettfreie Masse, FFM; Fettmasse, FM) mittels bioelektrischer Impedanzanalyse (BIA). Zusätzlich 
wurde der REE in Relation zum berechneten REE (Müller, 2004) gesetzt: \%REEAnthro, \%REEBIA. In einer weiteren Fall-Kontroll Studie (II) wurden 84 Frauen ein Jahr post RYGB (RYGB-Frauen) 1:1 mit 84 nicht-operierten nach Alter und BMI gematchten Kontrollen verglichen (Alter: $40,9 \pm 11,5$ vs. $41,0 \pm 11,8$ Jahre; $p=0,99$; BMI: $33,1 \pm 4,3$ vs. $\left.33,0 \pm 4,4 \mathrm{~kg} / \mathrm{m}^{2} ; \mathrm{p}=0,97\right)$.

Ergebnisse: In Studie I reduzierte sich der BMI der Frauen von $45,8 \pm 6,8$ auf $29,5 \pm 4,8 \mathrm{~kg} / \mathrm{m}^{2}$, bei den Männern von 46,0 $\pm 5,5$ auf $28,4 \pm 3,6 \mathrm{~kg} / \mathrm{m}^{2}$. Erwartungsgemäss war der absolute REE in beiden Geschlechtern nach RYGB deutlich niedriger (beide $p<0,001$ ). Der REE bezogen auf das Körpergewicht (REE/KG) war hingegen bei den Frauen $(16,5 \pm 2,0$ vs. $20,5 \pm 2,5 \mathrm{kcal} / \mathrm{kg} / \mathrm{d})$ und Männern $(18,2 \pm 2,3$ vs. $22,6 \pm 2,3$ $\mathrm{kcal} / \mathrm{kg} / \mathrm{d}$ ) postoperativ erhöht (beide $\mathrm{p}<0,001$ ). Bezogen auf die FFM sank der REE/FFM bei Frauen hingegen post RYGB ab $(p<0,001)$, jedoch nicht bei den Männern $(\mathrm{p}=0,1)$. \%REEAnthro und \%REEBIA waren postoperativ nur bei den Frauen angestiegen (beide $\mathrm{p} £ 0.007$ ). In Studie II war der absolute REE zwischen RYGB-Frauen und Kontrollen gut vergleichbar $(\mathrm{p}=0,56)$. Die RYGB-Frauen hatten einen höheren REE/KG im Vergleich zu den Kontrollen $(19,3 \pm 2,0$ vs. 18,5 $\pm 2,3$ $\mathrm{kcal} / \mathrm{kg} / \mathrm{d} ; \mathrm{p}=0,02)$, jedoch einen niedrigeren REE/FFM $(29,4 \pm 3,2$ vs. $31,1 \pm 3,7 \mathrm{kcal} / \mathrm{kg} / \mathrm{d} ; \mathrm{p}=0,009)$. \%REEAnthro und \%REEBIA waren nicht unterschiedlich (beide $p \geq 0,09$ ).

Schlussfolgerung: Die Daten zeigen keine eindeutige systematische Veränderung des REE nach einer RYGB-Operation. Es bleibt jedoch anzumerken, dass die Körperzusammensetzung lediglich mittels BIA erfasst wurde. Genauere Daten, beispielsweise mit DEXA oder MRT erhoben, erscheinen für weitere Analysen unabdingbar.

P69

\section{ATTITUDES TOWARDS BARIATRIC SURGERY IN THE GENERAL PUBLIC}

Sikorski, C. ${ }^{1}$; Luppa, M. ${ }^{1}$; Dame, K. ${ }^{1}$; Brähler, E. ${ }^{2}$; Schütz, T. ${ }^{3}$; König, H.-H. ${ }^{4}$; Riedel-Heller, S. G. ${ }^{1}$

${ }^{1}$ Institut für Sozialmedizin, Arbeitsmedizin und Public Health, Universität Leipzig, Leipzig, Germany; ${ }^{2}$ Abteilung für Medizinische Psychologie und Medizinische Soziologie, Universität Leipzig, Leipzig, Germany; ${ }^{3}$ IFB Adipositaserkrankungen, Universität Leipzig, Leipzig, Germany; ${ }^{4}$ Institut für Medizinische Soziologie, Sozialmedizin und Gesundheitsökonomie (IMSG), Universitätsklinikum Hamburg-Eppendorf, Hamburg, Germany

Background: Prevalence rates of obesity are still rising. Bariatric surgery $(\mathrm{BC})$ is the most radical but also most effective treatment option when efforts that are lifestyle-based have failed. Research indicates that health care professionals hold ambivalent views on bariatric surgery, while nothing is known about the views of the general public.

Methods: Of a German representative sample of $n=3.003$ respondents in a computer-assisted telephone interview, $\mathrm{n}=1.008$ persons were interviewed on their views of effectiveness towards bariatric surgery and other interventions for obesity. Also, willingness to recommend a treatment was assessed.

Results: Lifestyle-based interventions were seen most effective in terms of weight loss. About $50 \%$ of the population stated that BC is "very effective" while still a quarter of respondents did not ascribe effectiveness to BC. Higher age was associated with lower expectations of effectiveness, while higher stigmatizing attitudes and the view to find causes of obesity in genetics were associated with higher expectations of effectiveness. $72 \%$ would not recommend $\mathrm{BC}$ or undergo, if applicable, it themselves. Higher education and the opinion that $\mathrm{BC}$ was effective were associated with willingness of recommendation.

Conclusions: The German general public seems to be rather cautious regarding bariatric surgery. It may be assumed that false beliefs on the effectiveness and risk patterns of bariatric surgery are still very common, despite rising surgery numbers. Our results further emphasize the need for evidence-based information on bariatric surgery in the general public.
P70

\section{DER EINFLUSS EINER SCHWANGERSCHAFT AUF DEN GEWICHTSVERLAUF UND DIE EINNAHME VON SUPPLEMENTEN NACH EINER BARIATRISCHEN INTERVENTION}

Jelinek, V. ${ }^{1}$; Pernerstorfer, E. ${ }^{1}$; Möseneder, J. ${ }^{1}$; Karner, G. ${ }^{1}$

${ }^{1}$ Fachhochschule St. Pölten $\mathrm{GmbH}$, St. Pölten, Österreich

Fragestellung: Die bariatrische Chirurgie stellt einen wichtigen Baustein in der Therapie der Adipositas dar (Verband der Diätassistenten \& Hellbardt, 2011). Viele Frauen befinden sich zum Zeitpunkt der Operation im gebärfähigen Alter und haben ihre Familienplanung noch nicht abgeschlossen (Schultes, Ernst \& Thurnheer, 2010). Daher stellt das Thema Schwangerschaft nach bariatrischer Chirurgie einen wichtigen Bereich dar, der interdisziplinärer Zusammenarbeit bedarf.

Ziel dieser Bachelorarbeit ist es, den Einfluss einer Schwangerschaft auf den Gewichtsverlauf und die Einnahme von Supplementen nach einer bariatrischen Intervention zu untersuchen. Dadurch soll die Relevanz der diätologischen Betreuung aufgezeigt werden.

Methodik: Mittels quantitativer Fragebogenerhebung wurden $24 \mathrm{Ma}$ genband- (LAGB) und 11 Magenbypass- (RYGB) Patientinnen, die nach der Operation ein Kind zur Welt gebracht hatten, befragt. Es wurde der Gewichtsverlauf vor, während und nach der Schwangerschaft festgestellt sowie das Einnahmeverhalten von Supplementen erfragt. Ferner wurden im Rahmen einer qualitativen Befragung zwei Diätologinnen zur diätologischen Betreuungssituation dieser Patientengruppe interviewt.

Ergebnisse: Es wurde kein signifikanter Unterschied in der Gewichtszunahme von LAGB- und RYGB-Patientinnen während der Schwangerschaft gezeigt $(p=0,642)$. Ebenso konnte aufgrund der geringen Stichprobengröße kein signifikanter Unterschied in der Gewichtszunahme nach LAGB mit und ohne Bandweiterstellung festgestellt werden $(\mathrm{p}=0,212)$. Beinahe die Hälfte $(48,6 \%)$ aller Patientinnen wies eine Gewichtszunahme über den Empfehlungen auf. In der Einnahme von Supplementen konnte insgesamt eine geringe Compliance festgestellt werden, die sich durch das Bekanntwerden der Schwangerschaft nicht signifikant verändert hat $(\mathrm{p}=0,146)$. Bezüglich der Betreuung dieser Patientinnen in Österreich wurde eine unterschiedliche Intensität festgestellt.

Schlussfolgerung: In der diätologischen Betreuung dieser Patientengruppe ist auf eine ausreichende Nährstoffversorgung und die Einnahme von Supplementen, speziell während der Schwangerschaft, zu achten. Außerdem soll eine angemessene Gewichtszunahme während der Schwangerschaft angestrebt und rechtzeitig interveniert werden.

\section{P71}

\section{EINFLUSS EINER PROTEINSUBSTITUTION NACH BARIATRISCHER CHIRURGIE - EINE KONTROLLIERTE DOPPELBLINDE PILOTSTUDIE}

Friedrich, A. ${ }^{1}$; Karschin, J. ${ }^{1}$; Meile, $T^{2}$; Küper, M. ${ }^{2}$; Königsrainer, A. ${ }^{2}$; Bischoff, S.C. ${ }^{1}$

${ }^{1}$ Institut für Ernährungsmedizin, Universität Hohenheim, Stuttgart, Deutschland; ${ }^{2}$ Klinik für Allgemeine-, Viszeral- und Transplantationschirurgie, Universitätsklinikum Tübingen, Tübingen, Deutschland

Fragestellung: Die bariatrische Chirurgie ist eine immer häufiger eingesetzte Option der Adipositastherapie. $\mathrm{Zu}$ den bestehenden Risiken nach der Operation gehört neben möglichen Mikronährstoffmängeln auch der Eiweißmangel. Dieser führt zum Verbrauch körpereigener Proteinreserven, wobei zuerst Muskelprotein abgebaut wird, während Plasmaproteinkonzentrationen zunächst aufrechterhalten werden. Im Rahmen der geplanten Studie soll untersucht werden, ob das Risiko eines Eiweißmangels nach bariatrischer Chirurgie durch die Supplementation von Proteinen vermindert werden kann.

Methodik: 22 Adipositaspatienten, die sich einer bariatrischen Operation unterzogen, wurden in die Studie eingeschlossen. 11 Patienten erhielten postoperativ täglich $15 \mathrm{~g}$ (13,2 g Protein) eines Proteinpräparats der Firma Nestle (Protein 88) (Gruppe $1=$ G1) und 11 Patienten erhielten 
entsprechend ein Placebo bestehend aus Maltodextrin (Gruppe 2 = G2). Die Studienteilnehmer wurden vor der Intervention und ein Monat danach untersucht. Dabei wurden das Körpergewicht, die Körperzusammensetzung mittels Impedanzanalyse und die Serumproteine Albumin, Gesamteiweiß und Transferrin bestimmt.

Ergebnisse: Die durchschnittliche Proteineinnahme in G1 lag entgegen der Empfehlung nur bei 9,2 g Protein pro Tag. Der Gewichtsverlust ein Monat nach Intervention liegt bei $13,3 \mathrm{~kg}$ in $\mathrm{G} 1$ und bei $12,8 \mathrm{~kg}$ in $\mathrm{G} 2$ In G1 konnte das Übergewicht um 18,7 $\pm 5,9 \%$, in G2 um 19,7 $\pm 7,4 \%$, vermindert werden. In beiden Gruppen kommt es zu einer Reduktion von Körperfett (G1: $-1,2 \% ; \mathrm{G} 2$ : $-0,4 \%$ ), Magermasse (G1: $-4,7 \mathrm{~kg} ; \mathrm{G} 2$ : $-6,2 \mathrm{~kg}), \mathrm{BCM}(\mathrm{G} 1:-4,2 \mathrm{~kg} ; \mathrm{G} 2:-3,7 \mathrm{~kg})$, ECM (G1: -0,65 kg; G2: $-2,52 \mathrm{~kg})$, ECW (G1: $-3,57 \mathrm{~kg} ; \mathrm{G} 2:-2,95 \mathrm{~kg}$ ) prozentualem Zellanteil (G1: $-2,8 \%$; G2: $-0,8 \%$ ) und des Phasenwinkels (G1: $-0,52^{\circ}$; G2: $\left.-0,11^{\circ}\right)$. Dabei sind die Unterschiede zwischen den Gruppen nicht signifikant. Die mittleren Serumkonzentrationen von Gesamteiweiß und Albumin liegen zu jedem Zeitpunkt im Referenzbereich. Es besteht kein Unterschied zwischen den Gruppen. Transferrin nimmt in G2 im Vergleich zu G1 signifikant ab (G2: $-38,4 \mathrm{mg} / \mathrm{dl}$; G1: $-0,3 \mathrm{mg} / \mathrm{dl})$.

Schlussfolgerung: Die Substitution von Protein (9,2 g/Tag) nach bariatrischer Chirurgie scheint einen Monat postoperativ keinen signifikanten Einfluss auf die Veränderung der Körperzusammensetzung zu nehmen. Die unterschiedliche Entwicklung der Serumtransferrinkonzentration zwischen den Gruppen lässt vermuten, dass die Proteinsubstitution einem Eiweißmangel vorbeugen kann.

\section{P72}

\section{ANSTIEG DER SERUM OMENTIN-1 KONZENTRATION NACH EINEM 6-WÖCHIGEN AUSDAUERTRAINING BEI ADIPÖSER FRAUEN}

\section{Wilms, B. ${ }^{1}$; Gerig, R. ${ }^{1}$; Ernst, B. ${ }^{1}$; Frick, J. ${ }^{2}$; Thurnheer, M. ${ }^{1}$;} Schultes, $B{ }^{1}$

${ }^{1}$ Interdisziplinäres Adipositas-Zentrum, Kantonsspital St. Gallen, Rorschach, Schweiz; ' Institut für Bewegungswissenschaft und Sport, ETH Zürich, Zürich, Schweiz

Fragestellung: Ometin-1 ist ein Adipokin, das u.a. die Insulinwirkung verstärkt und zu kardiovaskulären Ereignissen invers assoziiert ist. Bei adipösen Personen sind die Omentin-1-Spiegel im Blut im Vergleich zu Normalgewichtigen vermindert. Erste Studien haben gezeigt, dass die Omentin-1-Konzentration durch eine energiereduzierte Diät oder Gewichtsreduktion kombiniert mit Training erhöht werden kann. Wir untersuchten, ob ein 6-wöchiges Ausdauertraining (3mal/Woche à 60 min) ohne diätetische Intervention einen Einfluss auf die Omentin-1Spiegel von adipösen Frauen hat.

Methodik: Die Interventionsgruppe (IG) umfasste 13 adipöse Frauen (Alter: 44,8 $\pm 3,3$ Jahre; BMI: $37,8 \pm 1,3 \mathrm{~kg} / \mathrm{m}^{2}$ ), die Kontrollgruppe (KG) 11 schlanke (Alter: 36,5 $\pm 3,1$ Jahre; BMI: $20,9 \pm 0,5 \mathrm{~kg} / \mathrm{m}^{2}$ ). Vor sowie nach 6 Wochen Training wurden in der IG Taillenumfang (TU), Fettmasse (FM), fettfreie Masse (FFM), nüchtern Ometin-1-, Glukose- und Insulin-Konzentrationen erfasst. Die kardiopulmonale Fitness wurde mittels 6-min-Gehtest (6MGT) sowie Fahrradergospirometrie bestimmt: absolute und relative (bezogen auf das Körpergewicht; $\mathrm{KG}$ ) $\mathrm{O}_{2}$ Aufnahme und Leistung bei Belastungsende ( $\mathrm{VO}_{2}$-peak; Watt-peak) und an aerob-anaerober Schwelle $\left(\mathrm{VO}_{2}-\mathrm{AT}\right.$; Watt-AT). In der KG wurde einmalig Omentin-1 gemessen.

Ergebnisse: Das Training hatte keinen Effekt auf das Gewicht $(p=0,99)$, senkte jedoch den TU $(\mathrm{p}=0,02)$ und erhöhte Omentin-1 (618 \pm 42 vs. $690 \pm 50 \mathrm{ng} / \mathrm{ml} ; \mathrm{p}=0,04)$. Vor als auch nach dem Training bestanden keine Unterschiede in Omentin-1 zwischen der IG und der KG (beide $\mathrm{p}>0,56)$. Das Training steigerte die Fitnessmarker Watt-peak, Wattpeak/KG und 6MGT (alle p>0.04). Weder TU, FM, FFM noch Glukose und Insulin waren vor bzw. nach Training mit Omentin-1 assoziiert (alle $\mathrm{p}>0,14)$. Auch die Veränderungen dieser Parameter nach 6 Wochen Training zeigten keine Beziehung zum Anstieg von Omentin-1 (alle $\mathrm{p}>0,63)$. Mit Ausnahme von $\mathrm{VO}_{2}$-peak $(\mathrm{p}=0,06)$ waren vor Training alle Fitnessmarker mit Omentin-1 korreliert (alle $r>0, .55$; alle $\mathrm{p}<0,05$ ). Nach 6 Wochen Training bestand eine Korrelation vom Omentin-1 mit $\mathrm{VO}_{2}$ AT und $\mathrm{VO}_{2}-\mathrm{AT} / \mathrm{KG}$ (beide $\mathrm{r}>0,59$; beide $\mathrm{p}<0,04$ ). Zudem korrelierten die Veränderungen von $\mathrm{VO}_{2}-\mathrm{AT}, \mathrm{VO}_{2}-\mathrm{AT} / \mathrm{KG}$ mit Omentin-1 (beide $r>0,57$; beide $\mathrm{p}<0,05$ ).

Schlussfolgerung: Unsere Daten zeigen erstmals eine erstaunlich enge Assoziation zwischen Omentin-1 und der körperlichen Fitness von adipösen Frauen. Es bleibt zu klären, ob hier eine kausale Beziehung besteht und ob Omentin-1 ein Marker für die körperliche Fitness darstellen könnte.

\section{P73}

\section{PILOT-STUDIE (MATCHED PAIRS) IM RAHMEN EINES MULTIMODALEN, INTERDISZIPLINÄREN ADIPOSITAS- THERAPIEPROGRAMMS MIT ZWEI FORMULADIÄT- FASTENPHASEN}

Bischoff, M. ${ }^{1}$; Hagen, H. $^{1}$; Bischoff, G. ${ }^{1}$; Wechsler, J.G. ${ }^{1}$

${ }^{1}$ Krankenhaus Barmherzige Brüder, München, Deutschland

Einführung und Fragstellung: Multimodale, interdisziplinäre Therapieprogramme* haben die besten Kurz- und Langzeitergebnisse. Ziel unserer Pilotstudie ist die Evaluation einer weiteren Fastenphase mit bilanzierter Formuladiät im Rahmen eines multimodalen Programms.*

Patienten und Methodik: In einer Pilot-Studie wurden 10 Teilnehmer, im Optifast52-Programm verglichen, mit 10 Teilnehmern die innerhalb des Programms eine zusätzliche zweite Fastenphase ( 8 Wochen) mit einer bilanzierten Formuladiät durchführten (matched pairs).

Die Teilnehmer werden über die gesamte Laufzeit interdisziplinär durch Ärzte, Psychologen, Ernährungsberater und Bewegungstherapeuten betreut.

Eine Fastenphase 5 Frauen, Alter 45, 136 kg, BMI 48, 5 Männer, Alter 42, $163 \mathrm{~kg}$, BMI 49

Zwei Fastenphasen 5 Frauen, Alter 46, 132 kg, BMI 49, 5 Männer, Alter 46, $165 \mathrm{~kg}$, BMI 48

Ergebnisse:

Eine Fastenphase 5 Frauen $\Delta \mathrm{g} 24,7 \mathrm{~kg} \Delta$ BMI 8,5 und 5 Männer $\Delta \mathrm{g} 28,3 \mathrm{~kg} \Delta \mathrm{BMI} \quad 8,8$

Zwei Fastenphasen 5 Frauen $\Delta \mathrm{g} 38,9 \mathrm{~kg} \quad \Delta$ BMI 14,4 und 5 Männer $\Delta \mathrm{g} 65,1 \mathrm{~kg} \Delta \mathrm{BMI} 18,9$

Parameter des metabolischen Syndroms konnten signifikant verbessert werden. Relevante Neben-wirkungen traten nicht auf.

Schlussfolgerung: Die Ergebnisse zeigen, dass der Erfolg eines multimodalen, interdisziplinären Therapieprogramms* durch die Einführung einer zweiten Formuladiät-Fastenphase signifikant gesteigert werden kann. In unserer Pilotstudie sind die Ergebnisse vergleichbar mit dem Gewichtsverlust, der durch bariatrisch-chirurgische Maßnahmen erzielt werden kann.

* Optifast ${ }^{\circledR} 52$ Programm

\section{P74 \\ EVALUATION EINES TAILORISIERTEN COMPUTERGESTÜTZTEN GEWICHTSMANAGEMENT- PROGRAMMS MIT 46.000 TEILNEHMERN}

Austel, A. ${ }^{1}$; Podzuweit, F. $^{2}$; Tempelmann, A. ${ }^{3}$; Stotz-Jonas, B. ${ }^{4}$; Ellrott, $T^{1}$.

${ }^{1}$ Institut für Ernährungspsychologie an der Universität Göttingen, Göttingen, Deutschland; ${ }^{2}$ Gesellschaft für Gesundheit \& Prävention, Göttingen, Deutschland; '3OK-Bundesverband, Geschäftsführungseinheit Versorgung, Abteilung Prävention, Berlin, Deutschland; ${ }^{4} \mathrm{Wdv}$ Gesellschaft für Medien \& Kommunikation, Bad Homburg, Deutschland

Fragestellung: Die AOK bietet ihren Versicherten unter dem Namen „Abnehmen mit Genuss“ ein verhaltensbasiertes ortsunabhängiges Gewichtsmanagementprogramm an. Das Programm dauert 6-12 Monate. Die Teilnahme ist freiwillig, die Kosten werden am Programmende erstattet. Über postalisch oder per Email übermittelte Ernährungstagebücher und Fragebögen zum Lebensstil wird mehrmals im Programmverlauf das Ess- und Bewegungsverhalten erfasst und ausgewertet. Basierend auf den persönlichen Angaben werden computergestützt 5 individuelle Beratungsbriefe mit persönlichen Trainingsempfehlungen generiert. Eine programmbegleitende Betreuung per Teilnehmerdienst (Tele- 
fon und e-Mail), individualisierte Informationen sowie Teilnehmerforen runden das Angebot ab. Der Erfolg dieses Programms wurde evaluiert. Methodik: Ausgewertet wurden die Daten aller 45.869 Teilnehmer (TN) ab 18 Jahren von 2006 bis 2010. 85,5\% der TN waren weiblich (mittleres Alter zu Programmbeginn 40,6 Jahre; mittlerer BMI 30,4 $\mathrm{kg} / \mathrm{m}^{2}$; mittleres Gewicht 84,0 kg; mittlere Waist-to-Height Ratio 0,62) und $14,5 \%$ männlich (44,5 Jahre; $\left.32,2 \mathrm{~kg} / \mathrm{m}^{2} ; 103,3 \mathrm{~kg} ; 0,64\right) .65 \%$ aller TN nahmen auf postalischem Weg, 35\% über Email teil. Körpergewicht und Bauchumfang wurden im Programmverlauf von den TN selbst erhoben und über die Fragebögen zurückgemeldet.

Ergebnisse: $50,4 \%$ der weiblichen und $54,0 \%$ der männlichen TN verließen das Programm vorzeitig (Abbrecher). Die mittlere Teilnahmedauer der Completers lag bei 285 Tagen. Die Gewichtsreduktion der Completers betrug im Mittel 4,4 kg (Frauen) bzw. 5,9 kg (Männer). Der BMI sank um $1,6 \mathrm{~kg} / \mathrm{m}^{2}$ bzw. $1,9 \mathrm{~kg} / \mathrm{m}^{2}$, die WHtR wurde auf $0,58 \mathrm{bzw}$. 0,60 reduziert. In der BOCF-Simulation (ungünstigste Annahme: Endgewicht $=$ Ausgangsgewicht bei Abbrechern) betrug die Gewichtsreduktion noch $2,2 \mathrm{~kg}$ bzw. $2,7 \mathrm{~kg}$, der BMI sank um $0,8 \mathrm{~kg} / \mathrm{m}^{2}$ bzw. 0,9 $\mathrm{kg} / \mathrm{m}^{2}$, die WHtR wurde auf 0,61 bzw. 0,62 reduziert. Alle Veränderungen waren im Wilcoxon-Test für verbundene Stichproben mit $\mathrm{p} \leq 0,0001$ signifikant.

Schlussfolgerung: Mit einen computergestützten ortsunabhängigen Gewichtsmanagementprogramm können sehr viele Teilnehmer erreicht werden. Etwa die Hälfte aller Teilnehmer absolviert das Programm bis zum Ende und kann mit Hilfe der tailorisierten Ernährungs- und Bewegungsempfehlungen eine relevante Gewichtsreduktion erreichen. Derartige Programme ergänzen von Fachkräften durchgeführte Vor-OrtProgramme. Sie sind orts- und zeitunabhängig verfügbar und zeichnen sich durch ein sehr gutes Kosten/Nutzen-Verhältnis aus.

\section{P75 \\ NUTZEN UND KLINISCHE RELEVANZ DER BIOELEKTRISCHEN IMPEDANZANALYSE IM OPTIFAST52-PROGRAMM}

\section{Stingel, K. ${ }^{1}$; Bischoff, S.C.}

${ }^{1}$ Institut für Ernährungsmedizin, Universität Hohenheim, Stuttgart, Deutschland

Fragestellung: Aufgrund der zunehmenden Inzidenz für Adipositas steigt der Bedarf an nachhaltigen Therapieprogrammen. Das einjährige Optifast $^{\circledR} 52$ Programm ist ein Beispiel für ein multimodales, ambulantes Gewichtsreduktionsprogramm zur Adipositastherapie beim Erwachsenen mit dem Einsatz von Formuladiät über 12 Wochen (Fastenphase). In der vorliegenden Arbeit wurde die Veränderung der Körperzusammensetzung während des Programmjahres analysiert. Es sollte geprüft werden, ob bestimmte Veränderungen der Körperzusammensetzung während der Fastenphase mit einem besseren Gesamterfolg der Gewichtsreduktion assoziiert sind.

Methodik: Insgesamt wurden 32 Patienten (25 Frauen und 7 Männer) in die Analyse mit einbezogen. Die Körperzusammensetzung wurde zu Beginn des Programms, nach 3, 6 und 12 Monaten mittels Bioelektrische Impedanzanlyse (BIA) gemessen. Die erhaltenen Daten wurden mit der NutriPlus Software von Data Input ausgewertet.

Ergebnisse: Während der Fastenphase reduzierten die Patienten ihr Gewicht um durchschnittlich 21,4 $\pm 5,4 \mathrm{~kg}$ (relativer Gewichtsverlust (RWL): 17,4 $\pm 3,6 \%$ ). Nach Programmabschluss lag der durchschnittliche Gewichtsverlust bei insgesamt 19,9 $\pm 12,2 \mathrm{~kg}$ (RWL: 16,0 \pm 9,3\%) Der Anteil des Körperfetts am Körpergewicht nahm während des Optifast ${ }^{\mathbb{B}}$ 52-Programms gegenüber dem Ausgangswert signifikant ab, wohingegen der Anteil der Magermasse sowie der Muskel- und Organzellmasse (BCM) signifikant zunahm. Während der Fastenphase reduzierte sich der Körperfettgehalt signifikant von 45,4 $\pm 6,5 \%$ auf $38,6 \pm$ $8,2 \%$. Nach Programmabschluss lag der Körperfettgehalt bei durchschnittlich 39,9 \pm 9,2\%. Der Anteil der Magermasse am Körpergewicht nahm während des Programms von 54,6 $\pm 6,4 \%$ auf $60,2 \pm 8,9 \%$ zu. Diese Zunahme spiegelte sich sowohl in der BCM als auch in der extrazellulären Masse wieder. Der Anteil der BCM am Körpergewicht stieg bei den Personen, die ihr Gewicht nach der Fastenphase weiter reduzierten, während des Programms signifikant an. Die BCM-Reduktion wäh- rend der Fastenphase unterschied sich nicht von Patienten, die nach der Fastenphase wieder Gewicht zugenommen haben.

Schlussfolgerung: Die BIA erweist sich als eine hilfreiche Methode, um die Veränderung der Körperzusammensetzung während des Optifast ${ }^{\circledR}$ 52-Programms zu beschreiben. Eine Erhöhung des Anteils der BCM am Körpergewicht während der Fastenphase kann ein Prädiktor für eine weitere Gewichtsabnahme während des Programms nach Fastenphase sein.

\section{P76}

ONLINE VERSUS FACE-TO-FACE: ANALYSE DER KURZUND LANGFRISTIGEN WIRKSAMKEIT EINES 12. WÖCHIGEN GEWICHTSREDUKTIONSPROGRAMMS

Borchardt, A. ${ }^{1}$; Pudel, S. ${ }^{2}$; Leonhäuser, I.-U. ${ }^{3}$; Ellrott, T. ${ }^{4}$

${ }^{1}$ Institut für Ernährungspsychologie an der Universität Göttingen, Universitätsmedizin / WeCARE Gesellschaft für Interdisziplinäres Gesundheitsmanagement mbh, Göttingen, Deutschland; ${ }^{2}$ WeCARE Gesellschaft für Interdisziplinäres Gesundheitsmanagement mbh, Göttingen, Deutschland; ${ }^{3}$ Institut für Ernährungswissenschaften, JustusLiebig-Universität, Gießen, Deutschland; ${ }^{4}$ Institut für

Ernährungspsychologie an der Universität Göttingen, Göttingen, Deutschland

Fragestellung: Inzwischen finden internetbasierte Gewichtsreduktionsprogramme weite Anwendung. Dennoch sind die Ergebnisse hinsichtlich ihrer Wirksamkeit uneinheitlich. In dieser Studie wurde die Wirksamkeit eines 12-wöchigen Gewichtsreduktionsprogramms untersucht: Online-Beratung vs. Face-to-Face-Beratung vs. Online-Beratung mit minimal in-person Betreuung.

Methodik: Dreiarmige, randomisierte, kontrollierte Vergleichsstudie: 33 Teilnehmer $(72,7 \%$ ㅇ, 27,3\% $\lesssim$ ) wurden der Internet-Gruppe (IG), 31 Teilnehmer $(54,8 \%$ o , 45,2\% 3 ) der Face-to-Face-Gruppe (FG) und 42 Teilnehmer $(57,1 \%$ \% , $42,9 \%$ \%) der Internet-Face-to-Face-Gruppe (IFG) zugeteilt. Das Durchschnittsalter betrug in der IG 46,7 $\pm 8,4$ Jahre, in der FG 47,6 \pm 13,3 Jahre und in der IFG 46,4 \pm 12,3 Jahre. Der BMI der IG lag im Mittel bei $29,8 \pm 2,7 \mathrm{~kg} / \mathrm{m}^{2}$, der Bauchumfang (BU) bei $98,8 \pm 9,1 \mathrm{~cm}$. In der FG lag der BMI bei $30,7 \pm 2,6 \mathrm{~kg} / \mathrm{m}^{2}$, der BU bei $101,0 \pm 10,2 \mathrm{~cm}$ und in der IFG bei $30,4 \pm 2,9 \mathrm{~kg} / \mathrm{m}^{2}$ bzw. 103,3 \pm $9,1 \mathrm{~cm}$. Das Programm umfasste Einheiten zur Ernährung, Bewegung und Verhaltensmodifikation. Die wöchentlichen Treffen fanden im Gruppensetting statt: die IG traf sich im moderierten Chat, die FG persönlich vor Ort und die IFG im Chat sowie einmal im Monat vor Ort. Gewicht und BU wurden vor Programmbeginn (T0), nach Programmende (T1) sowie 6 Monate (T2) und 12 Monate (T3) nach Programmende erhoben.

Ergebnisse: Die Auswertung erfolgte als Intention-to-Treat-Analyse (Modus: Baseline Observation Carried Forward). Bezogen auf die Ausgangswerte lagen die mittleren Gewichtsabnahmen zu T1, T2 und T3 bei 2,5 $\pm 2,5 \mathrm{~kg}, 2,0 \pm 3,3 \mathrm{~kg}$ bzw. $1,4 \pm 2,7 \mathrm{~kg}$ in der IG; bei $5,6 \pm$ $4,2 \mathrm{~kg}, 5,3 \pm 5,1 \mathrm{~kg}$ bzw. 4,4 $\pm 5,1 \mathrm{~kg}$ in der FG und bei $3,7 \pm 3,7 \mathrm{~kg}$, 2,8 $\pm 4,1 \mathrm{~kg}$ bzw. 2,2 $\pm 4,0 \mathrm{~kg}$ in der IFG. Der BU konnte in der IG im Durchschnitt um $3,1 \pm 2,7 \mathrm{~cm}, 2,7 \pm 3,3 \mathrm{~cm}$ bzw. $2,3 \pm 3,1 \mathrm{~cm}$; in der FG um $4,1 \pm 3,5 \mathrm{~cm}, 4,3 \pm 4,6 \mathrm{~cm}$ bzw. $3,6 \pm 4,4 \mathrm{~cm}$ und in der IFG um $4,0 \pm 4,3 \mathrm{~cm}, 3,7 \pm 4,8 \mathrm{~cm}$ bzw. $3,3 \pm 4,8 \mathrm{~cm}$ reduziert werden. Diese Veränderungen waren in allen Gruppen signifikant $(p<0,05)$.

Schlussfolgerung: Sowohl durch internetbasierte als auch durch persönliche Beratung bzw. durch die Kombination beider lässt sich kurz- und langfristig eine signifikante Reduktion des Gewichts sowie des Bauchumfangs erreichen. Allerdings zeigt sich, dass das Vor-Ort-Programm dabei am wirksamsten ist. 


\section{P77}

\section{WEIGHT MAINTENANCE TREATMENT APPROACH FOR ADOLESCENT OBESITY VIA TELEPHONE COUNSELING FOLLOWING AN INPATIENT OBESITY TREATMENT PROGRAM - STUDY CONCEPT}

Markert, J. ${ }^{1}$; Herget, S. ${ }^{1}$; Marschke, S. ${ }^{1}$; Vogel, M. ${ }^{2}$; Hilbert, A. ${ }^{1}$; Blüher, S. $^{1}$

${ }^{1}$ Integrated Research and Treatment center (IFB) Adiposity Diseases, University of Leipzig, Leipzig, Germany; ${ }^{2}$ CrescNet gGmbH, University of Leipzig, Leipzig, Germany

Objective: The purpose of obesity treatment is to sustainably reduce body weight. Maintaining weight loss remains a challenge. This study aims to evaluate a) the feasibility and b) the efficacy of a structured weight-maintenance program based on telephone counseling for adolescents after structured obesity therapy (reconvalescent care).

Methods: Recruitment is performed via German rehabilitation hospitals. The intervention starts within 6 weeks after completion of obesity therapy. Inclusion criteria: 14-18 years, completion of inpatient obesity therapy. Exclusion criteria: current involvement in weight loss treatment, psychiatric conditions (e.g. eating disorder, psychosis), medication and/or underlying chronic disease interfering with participation and/or weight maintenance. Feasibility study (performed for 4 months, 2 intervention groups, 1 control group): There are two distinct modes of intervention: 1.) telephone counseling and tailored SMS messages, and 2.) telephone counseling, tailored SMS messages and access to a password-protected web-forum for interaction with other participants. Afterwards acceptance and adherence will be evaluated. Efficacy study (performed for 6 months, 1 intervention group, 1 control group): The mode of intervention superior over the other, which is in favor of adolescents (best adherence) and researchers (best effect size) is applied in the efficacy study. Control groups: No intervention, medical care as usual. The primary endpoint is change in BMI-SDS within 6 months following randomization. Secondary endpoints (psychosocial parameters, physical activity, and eating behavior) are assessed by questionnaires. The telephone interviews are performed by trained prevention managers (Bachelor of sciences in psychology) according to a standardized manual following the solution focused counseling after De Shazer, a systemic approach. Each counseling interview takes 20-30 minutes and addresses the adolescents directly. To ensure sustainability within the family setting one coaching interview is held with the adolescent and his/her parents together. One and two years following randomization follow-up assessments are conducted.

Discussion: Structured and validated weight maintenance approaches for adolescent obesity are urgently needed to ensure long-term success of obesity therapy programs. This study shall provide data on feasibility and efficacy of a telephone-based weight maintenance intervention directly addressing adolescents.

\section{P78}

\section{AUS DER ÄRZTLICHEN PRAXIS: ERFAHRUNGEN MIT EINEM AMBULANTEN KURZZEITPROGRAMM ZUR GEWICHTSREDUKTION BEI ÜBERGEWICHTIGEN ERWACHSENEN}

Schaffner, $D .{ }^{1}$; Stensitzky, A. ${ }^{1}$; Deibert, $P .{ }^{1}$; König, $D .{ }^{1}$; Berg, $A .{ }^{1}$

${ }^{1}$ Institut für Präventive Medizin, Freiburg, Deutschland

Fragestellung: Da Ergebnisse aus klinischen Studien nicht das Bild der ambulanten Versorgung von übergewichtigen Erwachsenen realistisch widerspiegeln, wurden Erfahrungen mit einem ambulanten Kurzzeitprogramm zur Gewichtsreduktion bei übergewichtigen Erwachsenen gesammelt. Dies erscheint notwendig, da positive Initialerfolge oftmals den Anschub für eine weitere Gewichtsabnahme und auch Gewichtsstabilisierung geben können.

Methodik: Nach einem regionalen tv-Bericht zum Thema „Abnehmen mit Erfolg" meldeten sich 55 übergewichtige und adipöse Erwachsene aus dem Raum Freiburg im IPM, um an einem 6 wöchigen Programm zur Gewichtsreduktion teilzunehmen. Nach erfolgter Eingangsuntersuchung und einem Informationsgespräch konnten 48 Patienten $\left(49,9 \pm 13,9 \mathrm{~J}, 34,2 \pm 4,7 \mathrm{~m} / \mathrm{kg}^{2}\right)$ in das Programm eingeschlossen werden; 7 Anmeldungen mussten wegen Primärerkrankungen oder fehlender Bereitschaft ausgeschlossen werden. Die Intervention erfolgte nach einem im IPM entwickelten Konzept bestehend aus ausführlicher Beratung zur Energiebilanzierung, dem Angebot eines Mahlzeitenersatzes auf Sojabasis (Almased $\AA$, 2x täglich, standardisiert nach $K G$ ) und der Möglichkeit zur telefonischen Begleitung. 40 der eingeschlossenen Patienten schlossen die Intervention $a b$ und nahmen an einer Abschlussuntersuchung teil.

Ergebnisse: Bei vergleichbarem Übergewicht waren die weiblichen Completer jünger $(n=23,46,2 \pm 14,1 \quad J)$ als die männlichen $(n=17$, $55,0 \pm 12,1 \mathrm{~J}$ ) und zeigten auch weniger Begleiterkrankungen; deutlich älter war die Subgruppe (SG) der Patienten mit MS und T2DM ( $\mathrm{n}=12$, $60,8 \pm 5,9 \mathrm{~J})$. Alle Completer zeigten eine deutliche Gewichtsabnahme nach Intervention: weibl. $93,4 \pm 14,9$ auf $88,8 \pm 14,9 \mathrm{~kg}(-5,3 \%)$, männl. $108,9 \pm 12,0$ auf $102,8 \pm 13,3(-5,6 \%)$, SG $103,2 \pm 11,8$ auf $97,0 \pm 11,8$ $(-6,0 \%)$. Die Gewichtsabnahme war mit einer signifikanten Reduktion der begleitenden Risikofaktoren begleitet, besonders ausgeprägt für die SG-Patienten, z.B. Triglyz. 328 \pm 241 auf $175 \pm 79 \mathrm{mg} / \mathrm{dl}$, NBZ $131 \pm 37$ auf $105 \pm 14 \mathrm{mg} / \mathrm{dl}$. Mit 17\% lag die Zahl der Drop-outs in einem vertretbaren Bereich.

Schlussfolgerung: Die Ergebnisse zeigen, dass in einem begleiteten ambulanten Kurzzeitprogramm Männer wie Frauen erfolgreich an Gewicht verlieren und auch Patienten mit gestörter BZ-Regulation bereits nach 6 wöchiger Intervention erhebliche Gesundheitsvorteile erzielen können. Nachfolgeuntersuchungen bestätigen zudem, dass schnell erzielte Erfolge die Patienten in ihrem Willen stärken, auch weiterhin ihr Gewicht zu reduzieren.

Die Studie wurde von der Firma Almased GmbH, Bienenbüttel finanziell unterstützt.

\section{Epidemiologie / Risikofaktoren \\ P85 \\ DAS METABOLISCHE SYNDROM UND SEINE RISIKOFAKTOREN: PRÄVALENZ IN EINEM GROSSEN DEUTSCHEN UNTERNEHMEN DER AUTOMOBILINDUSTRIE}

Schaller, N. ${ }^{1}$; Bischof, J. ${ }^{2}$; Hanssen, $H^{3}{ }^{3}$; Zelger, O. ${ }^{1}$; Blume, . $^{1}$; Schuster, ${ }^{4}$; Haller, B. ${ }^{4}$; Schmidt-Trucksäss, A. $^{3}$; Halle, M. $^{1}$ ${ }^{1}$ Zentrum für Prävention und Sportmedizin, Klinikum Rechts der Isar, TU München, München, Deutschland; ${ }^{2}$ Gesundheitsmanagement, BMW Group, München, Deutschland; ${ }^{3}$ Institut für Sport und Sportwissenschaften, Universität Basel, Schweiz; ${ }^{4}$ Institut für Medizinische Statistik und Epidemiologie, Technische Universität München, München, Deutschland

Hintergrund: Im Hinblick auf den demografischen Wandel gewinnt der altersbezogene Gesundheitsstatus der Arbeitnehmer zunehmende Bedeutung.

Methodik: In den Jahren 2006-2007 wurden die Mitarbeiter ( ÆE: 39,6 10,0 Jahre, $85 \%$ Männer) eines großen deutschen Unternehmens der Automobilindustrie untersucht. Zur Auswertung mit nüchterner Blutabnahme lagen 2920 vollständige Datensätze (10,7\% des Gesamtkollektivs) vor. Es wurden biometrische Parameter (Größe, Gewicht, Taillenumfang), Blutwerte (Lipide, Glukose, HbAlc, hs-CrP) sowie die Prävalenz der Risikofaktoren des metabolischen Syndroms (nach NCEP ATP III) bestimmt. Lebensstilfaktoren wie Rauchverhalten, Obst- und Gemüseverzehr und sportliche Betätigung wurden per Fragebogen ermittelt.

Ergebnisse: Bei 6,5\% der Männer bzw. 3,6\% der Frauen wurde die Diagnose „Metabolisches Syndrom“ gestellt (Anzahl der Risikofaktoren $\geq 3$ ), wobei sich dieser Anteil mit steigendem Alter deutlich erhöhte ( $\geq$

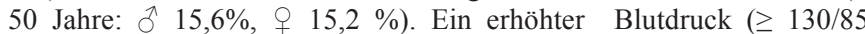
$\mathrm{mmHg}$ ) war bei $57,7 \%$ der Männer und $75,7 \%$ der Frauen am häufigsten zu finden, gefolgt von Nüchtern-Triglycerid-Werten $\geq 150 \mathrm{mg} / \mathrm{dl}$ ( ${ }^{\top}$ : $32,5 \%$, + : 13,8\%) und einem Taillenumfang $>102 \mathrm{~cm}\left(\delta^{\top}: 14,7 \%\right)$ bzw. $>88 \mathrm{~cm}$ (ㅇ: $17,2 \%)$. Die metabolischen Risikofaktoren häuften sich bei Mitarbeitern mit wenig sportlicher Aktivität an. Letztere ließ mit zu- 
nehmendem Alter deutlich nach, so dass sich die Prävalenz des metabolischen Syndroms in der Gruppe der inaktiven über 50-jährigen Männer auf $21,9 \%$ erhöhte.

Schlussfolgerung: Aufgrund der zunehmenden Prävalenz des Metabolischen Syndroms mit ansteigendem Alter der Betriebsangehörigen, sollten betriebliche Präventionsprogramme bereits für jüngere Mitarbeiter $(<50$ Jahre) angeboten werden. Sie sollten auf die Verbesserung des Lebensstils im Sinne eines aktiveren Bewegungsverhaltens zur Vermeidung von Übergewicht und Adipositas als Eintrittspforte des Metabolischen Syndroms abzielen.

\section{P86}

\section{KÖRPERWAHRNEHMUNG VON 9-11-JÄHRIGEN KINDERN UND DEREN ELTERN - ERGEBNISSE DER KIELER ADIPOSITAS-PRÄVENTIONSSTUDIE (KOPS)}

Gose, M. ${ }^{1}$; Plachta-Danielzik, S. ${ }^{1}$; Fangmann, D. ${ }^{1}$; Gehrke, M.I. ${ }^{1}$; Landsberg, B. ${ }^{1}$; Müller, M.J. ${ }^{1}$

${ }^{1}$ Institut für Humanernährung und Lebensmittelkunde, Christian-AlbrechtsUniversität, Kiel, Deutschland

Fragestellung: Ziele der Untersuchung waren, die Unterschiede zwischen Selbstwahrnehmung und objektiv erfasstem Ernährungszustand von Kindern und Eltern zu ermitteln, die Einschätzung von Kindern und Eltern in Bezug auf den Ernährungszustand des Kindes zu vergleichen und Determinanten der Körperwahrnehmung zu bestimmen.

Methodik: Bei 1194 9-11-jährigen Kindern wurden Größe und Gewicht gemessen und deren Ernährungszustand über den Body-Mass-Index (nach Kromeyer-Hauschild et al., 2001) bestimmt. Größe und Gewicht der Eltern waren Selbstangaben (Väter: n=744; Mütter: n=791; Alter: 42 (38-45) Jahre). In einem Interview wurden die Kinder befragt, wie sie ihren Körper einschätzen würden (viel zu dünn, etwas zu dünn, normal, etwas zu dick, viel zu dick). Die Eltern wurden in einem Fragebogen gebeten, ihren eigenen Körper und den ihres Kindes bzgl. des Gewichts $\mathrm{zu}$ beurteilen. Zusätzlich wurde der sozio-ökonomische Status (SES) anhand des Bildungsstatus der Eltern erfasst.

Ergebnisse: $16,7 \%$ der Kinder und 47,2\% der Eltern waren übergewichtig oder adipös. $2 / 3$ der Kinder schätzten ihren Körper richtig ein, 14,7\% unterschätzten und 18,7\% überschätzten sich. Die Beurteilung der Jungen entsprach häufiger dem objektiven Ernährungszustand als die der Mädchen (70,4\% vs. 63,0\%; p<0,01). 78,4\% der Mütter und 62,2\% der Väter hatten eine korrekte Wahrnehmung ihres eigenen Körpers. 9,8\% bzw. 9,4\% der Eltern unterschätzten bzw. überschätzten ihre Kinder Beurteilten Eltern ihre Kinder korrekt, nahmen sich auch Kinder häufiger richtig wahr. Die Wahrnehmung von Kindern und Eltern stimmte seltener mit dem objektiven Ernährungszustand überein, wenn die Kinder übergewichtig/adipös waren oder einen niedrigen SES hatten. Im Vergleich zu normalgewichtigen Müttern, unterschätzten sich die Kinder häufiger, wenn ihre Mütter übergewichtig waren (OR: 2,154; $\mathrm{p}<0,05)$.

Schlussfolgerung: Übergewichtige oder adipöse Kinder schätzen ihren Ernährungszustand häufig falsch ein bzw. werden auch von ihren Eltern nicht korrekt wahrgenommen. Eltern haben zudem einen starken Einfluss auf die Körperwahrnehmung ihrer Kinder. Zukünftig sind Strategien, die die Körperwahrnehmung von Kindern und Eltern verbessern notwendig, damit Übergewicht bei Kindern von sowohl Eltern als auch von Kindern selbst erkannt wird und um darauf aufbauend die Bereitschaft zu erhöhen, den Lebensstil positiv zu verändern.

\section{P87}

\section{VERLAUFSMUSTERENTWICKLUNG IN DER CHIRURGISCHEN BEHANDLUNG BEI MORBIDER ADIPOSITAS DER JAHRE 1992-2012}

\section{Hesse, U. ${ }^{1}$; Böttger, T. ${ }^{1}$; Hommel, E. ${ }^{2}$}

${ }^{1}$ Euromedclinic, Fürth, Deutschland; ${ }^{2}$ Gastroenterologisch-

Viszeralchirurgisches Facharztzentrum, Deutschland

Hintergrund: Bei aussichtsloser konservativer Therapie der morbiden Adipositas haben die minimalinvasiven chirurgischen Maßnahmen eine zunehmende Akzeptanz erfahren.
Chirurgische Techniken und damit auch klinische Verläufe im Hinblick auf Indikation, Morbidität und Mortalität, Kostenübernahme durch die Krankenkassen, Folgeoperationen und das Qualitätsmanagement haben sich mit der Zeit signifikant verändert.

Ziel: Die Analyse der Verlaufsmuster bei Patienten, die einer minimalinvasiven Chirurgischen Therapie in den letzten 20 Jahren unterzogen wurden ist Gegenstand der vorliegenden Arbeit.

Patienten und Methoden: In 5 Untergruppen wurden die Verläufe offen/MIC(1), Magenband/Bypass (2), Bypass/Sleeve(3) im Hinblick auf Inzidenz, Klinikverweildauer, Morbidität und Mortalität, Kostenübernahme/Selbstzahler/Ablehnung (4) und REDO Operationen (5) analysiert.

Der Student-t test und der $\mathrm{X}^{2}$-Test und wurden zur statistischen Auswertung der quantitativen und qualitativen Unterschiede der Mittelwerte+/SD bzw absoluter Werte eingesetzt. Signifikanz war bei $\mathrm{p}<0,05$ gegeben.

Ergebnisse: Aus einer Gesamtzahl von 2241 Verläufen ergab sich in Gruppe $1(\mathrm{n}=806)$ bei offenen Operationen 100\%, (MW) 16 Tage und $0,5 \%$ vs MIC $(100 \%) 4$ Tage und $0 \%,(\mathrm{p}<0,05)$. In Gruppe $2(\mathrm{n}=418)$ $317 / 101$, in Gruppe $3(n=42) 3 / 39$, in Gruppe $4(n=656) 33,8 / 2,2 \%$ (Gruppe 2) vs $80 / 10 \%$ (Gruppe3) $\mathrm{p}<0,05$. In Gruppe $5(\mathrm{n}=219)$ betrug die Morbidität 29,3\% und die Letalität 0\%.

Schlussfolgerung: Die Verlaufsmuster in der bariatrischen Chirurgie haben sich in den vergangenen 20 Jahren mit der Etabilierung der Minimalinvasiven Techniken, Leitlinien und Qualitätsmanagement zur reduzierten Krankenhausverweildauer, verbesserten Morbiditäts-und Mortalitätsraten und zunehmender Reduzierung des OP Umfangs (Sleeveresektion) entwickelt. Die Kostenübernahmen konnten gesteigert werden und bei zunehmender Frequenz an REDO- Operationen konnte die Mortalität bei erheblicher Morbidität sehr gering gehalten werden.

\section{P88 \\ MAXIMALE ERFOLGE VON PRÄVENTION VON ÜBERGEWICHT BEI KINDERN UND JUGENDLICHEN: MÜSSEN UNTERSCHIEDLICHE STRATEGIEN FÜR VERSCHIEDENE RISIKOGRUPPEN VON ÜBERGEWICHT UND ADIPOSITAS GEWÄHLT WERDEN? (TP 1 IM VERBUND PREVENT DES KOMPETENZNETZ ADIPOSITAS)}

Plachta-Danielzik, S. ${ }^{1}$; Kehden, B. ${ }^{1}$; Landsberg, B. ${ }^{1}$; Schaffrath Rosario, A. ${ }^{2}$; Kurth, B.-M. ${ }^{2}$; Arnold, C. ${ }^{3}$; Graf, $C^{3}{ }^{3}$; Hense, S. ${ }^{4}$; Ahrens, W. ; Müller, M.J. ${ }^{5}$

${ }^{1}$ Institut für Humanernährung und Lebensmittelkunde, Christian-AlbrechtsUniversität Kiel Institut für Humanernährung, Kiel, Deutschland; ${ }^{2}$ Robert Koch-Institut, Berlin, Deutschland; ${ }^{3}$ Deutsche Sporthochschule, Köln, Deutschland; ${ }^{4}$ Bips, Bremen, Deutschland; ${ }^{5}$ Institut für Humanernährung und Lebensmittelkunde, Kiel, Deutschland

Fragestellung: Wie groß ist die maximale Effektivität von Prävention für Übergewicht und Adipositas und sind die Determinanten in den verschiedenen Risikogruppen gleich bedeutsam?

Methodik: Daten von 34.240 gesunden Kindern und Jugendlichen (317 Jahre) aus 4 deutschen Studien. Definition von Risikogruppen anhand der deutschen BMI-Referenzperzentile (Kromeyer-Hauschild et al. 2000): (i) Risiko für Übergewicht (=Gruppe 1): >P75; (ii) Übergewicht (=Gruppe 2): >P90; (iii) Adipositas (=Gruppe 3): >P97. Betrachtete Determinanten: biologische Faktoren (Übergewicht und Adipositas der Eltern), soziale Faktoren (Bildung der Eltern, Alleinerziehende, Rauchverhalten der Eltern), frühkindliche Faktoren (Rauchen während der Schwangerschaft, Gewichtszunahme der Mutter während der Schwangerschaft, Geburtsgewicht, Stillen) und Lebensstil (Medienkonsum, Aktivität). Die Relevanz der Determinanten der 3 Risikogruppen wurde durch Berechnung multivariater attributabler Risiken (ARs) (gemeinsames AR für alle Determinanten, partielle ARs für einzelne Determinanten) geschätzt.

Ergebnisse: Die Prävalenz von Gruppe 1 lag bei 28,1\%, die von Gruppe 2 betrug $13,4 \%$ und $5,1 \%$ der Kinder waren adipös (Gruppe 3). Die erfolgreiche Elimination aller Determinanten verringerte die Prävalenz von Gruppe 1 um $61,2 \%$ (von 28,1 auf 10,9\%), die von Gruppe 2 um $78,1 \%$ (von 13,4 auf 2,9\%) und die von Gruppe 3 um 87,3\% (von 5,1 
auf $0,6 \%$ ). Die Bedeutung biologischer Faktoren und des Lebensstils stieg mit der Ausprägung des Übergewichts, während die Bedeutung sozialer und frühkindlicher Faktoren in den 3 Risikogruppen gleich war (partielle ARs: biologische Faktoren: 36,2\% (P75), 42,6\% (P90), 47,2\% (P97); Lebensstil: 6,2\% (P75), 11,7\% (P90), 17,2\% (P97); soziale Faktoren: 9,8\% (P75), 14,4\% (P90), 14,4\% (P97); frühkindliche Faktoren: 9,0\% (P75), 9,4\% (P90), 8,5\% (P97)).

Schlussfolgerung: Präventionsmaßnahmen erreichen alle Gruppen und sind bereits bei Vorliegen von Risiken wirksam. Die Bedeutung der Determinanten ist unterschiedlich: mit Zunahme des Übergewichts werden die biologischen Faktoren und die Lebensstilfaktoren bedeutsamer.

\section{P89}

\section{DIE PLASMAINSULINKONZENTRATIONEN IM NABELSCHNURBLUT SOWIE IM ALTER VON 8 JAHREN SIND MIT DEM BMI VERLAUF SEIT DER GEBURT ASSOZIIERT - ERGEBNISSE DER ULMER GEBURTSKOHORTE (UBCS)}

Brandt, S. ${ }^{1}$; Moß, A. ${ }^{1}$; Gottmann, . $^{1}$; Koenig, W. ${ }^{2}$; Weck, M. ${ }^{3}$; Brenner, $H^{3}{ }^{3}$; Wabitsch, M. $^{1}$

${ }^{1}$ Sektion Pädiatrische Endokrinologie und Diabetologie, Universitätsklinik für Kinder- und Jugendmedizin, Ulm, Deutschland; ${ }^{2}$ Zentrum für Innere Medizin, Klinik für Innere Medizin II, Universitätsklinikum, Ulm, Deutschland; ${ }^{3}$ Abteilung Klinische Epidemiologie und Alternsforschung, Deutsches Krebsforschungszentrum, Heidelberg, Deutschland

Hintergrund: Der BMI steigt physiologisch nach der Geburt an und erreicht sein höchstes Niveau im Alter von einem Jahr. Im Anschluss daran fällt der BMI ab, erreicht sein niedrigstes Niveau im Vorschulalter und steigt anschließend wieder an. Die Identifizierung von Faktoren, die mit einem abweichenden BMI-Verlauf assoziiert sind, steht im Fokus des aktuellen Interesses.

Fragestellung: Sind die Insulinkonzentrationen im Nabelschnurblut und im Alter von 8 Jahren mit dem BMI-Verlauf seit der Geburt assoziiert?

Methoden: Die Ulmer Geburtskohorte (UBCS) ist eine prospektive Studie mit longitudinalem Design. Während der Baseline-Erhebung konnten n=1066 Mütter und deren Neugeboren für die Teilnahme an der Studie rekrutiert werden. Bei der Geburt der Kinder wurde eine Nabelschnurblutprobe entnommen und eingelagert. Daten über den Körpergewichts- und -höhenverlauf der Kinder ( $0-8$ Jahre) wurden erhoben. Im 8-Jahres follow-up der UBCS wurde eine Nüchternblutprobe von $n=499$ Kindern entnommen. Die Insulinkonzentration in der Nabelschnurblut (high sensitive ELISA) sowie die Nüchterninsulinkonzentration im Plasma des 8 jährigen Kindes wurden gemessen (ELISA,n=453) und in Quartile eingeteilt. Die Kinder, die eine Insulinkonzentration im Nabelschnurblut sowie eine Nüchterninsulinkonzentration im Alter von 8 Jahren im 4. Quartil aufwiesen, wurden als "Risikogruppe" definiert Kinder, die dieses Kriterium nicht erfüllten, wurden als „Referenzgruppe" definiert. Der BMI Verlauf der Kinder der Risikogruppe wurde mit dem BMI Verlauf der Kinder der Referenzgruppe verglichen.

Ergebnisse: Kinder der Risikogruppe besaßen bei der Geburt einen signifikant höheren BMI im Vergleich zu den Kindern der Referenzgruppe (Differenz $=0,4 \mathrm{~kg} / \mathrm{m}^{2}$ ). Im weiteren Verlauf lag der BMI der Kinder der Risikogruppe deutlich oberhalb dem BMI der Kinder der Referenzgruppe. Während bei der Risikogruppe der BMI nach dem 4 bis zum 6. Geburtstag um $0,29 \mathrm{~kg} / \mathrm{m}^{2}$ anstieg, war bei der Referenzgruppe eine Abnahme des BMI um $0,03 \mathrm{~kg} / \mathrm{m}^{2}$ zu verzeichnen $(p=0,151)$. Ein starker Anstieg im BMI bestand für Kinder beider Gruppen zwischen 6 und 8 Jahren, der stärker bei den Kindern der Referenzgruppe war $\left(+0,87 \mathrm{~kg} / \mathrm{m}^{2}\right.$ vs. $\left.+1,31 \mathrm{~kg} / \mathrm{m}^{2}, \mathrm{p}<0.0001\right)$. Kinder der Risikogruppe besaßen im Alter von 8 Jahren einen signifikant höheren BMI im Vergleich zu den Kindern der Referenzgruppe $\left(+1,49 \mathrm{~kg} / \mathrm{m}^{2}\right)$.

Schlussfolgerung: Es wird angenommen, dass eine höhere Sekretionsleistung der ß-Zelle die frühkindliche BMI-Entwicklung nachhaltig positiv beeinflusst.
P90

\section{GESTATIONSDIABETES UND DAS RISIKO FÜR KINDLICHES ÜBERGEWICHT}

Nehring, I. $^{1}$; Chmitorz, A. ${ }^{1}$; Albers, L. ${ }^{1}$; Reulen, H. $^{1}$; von Kries, R. ${ }^{1}$; Ensenauer, R. $^{1}$

${ }^{1}$ Ludwig-Maximilians-Universität, München, Deutschland

Objective: Gestational diabetes mellitus (GDM) is believed to be a potential risk factor for childhood overweight/ obesity. To assess whether this association is causal or a reflection of confounding by maternal BMI, a large cohort was analyzed including several confounders. In order to increase precision and external validity, a meta-analysis on related studies was performed.

Design: Data of 7370 mother-child dyads with full information on maternal and children's anthropometric data and GDM were available from the German PEPO cohort. We calculated crude and adjusted logistic regression models for the association of GDM and childhood overweight or obesity, respectively. A systematic literature search and meta-analysis on similar studies was performed using a random effects model.

Results: Analyses with adjustment for maternal BMI and other potential confounders yielded an odds ratio (OR) of 1.58 ( $95 \%$ confidence interval (CI): $1.08 ; 2.31$ ) for the impact of GDM on overweight (on obesity: $\mathrm{OR}=2.40(95 \%$ CI: $1.36 ; 4.26))$. Inclusion of birth weight in the model did not change the estimates. The meta-analysis of six cohorts confirmed these results $(\mathrm{OR}=1.34$ (95\%CI: 1.06; 1.69)).

Conclusions: The postulated increased risk of overweight in offspring of mothers with GDM cannot be explained by maternal BMI alone and might be stronger in obese offspring. Birth weight is unlikely to be in the causal pathway between GDM and childhood overweight/ obesity.

\section{P91}

\section{KARDIORESPIRATORISCHE FITNESS ALS DETERMINANTE KARDIOMETABOLISCHER RISIKOFAKTOREN BEI PERSONEN MIT AUSGEPRÄGTER ADIPOSITAS}

\section{Waldburger, . $^{1}$; Wilms, B. ${ }^{1}$; Ernst, B. ${ }^{1}$; Schultes, $B .{ }^{1}$}

${ }^{1}$ Interdisziplinäres Adipositas Zentrum, Kantonsspital St. Gallen, Rorschach, Schweiz

Einleitung: Eine Vielzahl an Studien hat eine inverse Beziehung zwischen kardiorespiratorischer Fitness und kardiometabolischen Risikofaktoren sowie dem Auftreten von kardiovaskulären Krankheiten in normalgewichtigen bis leicht adipösen Menschen gezeigt. Nicht bekannt ist, ob eine solche Beziehung auch bei sehr ausgeprägt adipösen Personen $\left(B M I \geq 35,0 \mathrm{~kg} / \mathrm{m}^{2}\right)$ besteht.

Methodik: Die kardiorespiratorische Fitness wurde mittels Fahrradergospirometrie bei 308 extrem adipösen Frauen (BMI: 44,6 $\pm 5,6 \mathrm{~kg} / \mathrm{m}^{2}$, Alter: $39,5 \pm 11,3$ Jahre) und 133 Männern (BMI: $45,8 \pm 6,0 \mathrm{~kg} / \mathrm{m}^{2}$, Alter: $44,2 \pm 11,3$ Jahre) erfasst. Gemessen wurden die $\mathrm{O}_{2}$-Aufnahme und Leistung bei Belastungsende ( $\mathrm{VO}_{2}$-peak; Watt-peak) sowie an der aerob-anaeroben Schwelle $\left(\mathrm{VO}_{2}\right.$-AT; Watt-AT). Folgende kardiometabolischen Risikomarker wurden in Blutproben bestimmt: Glukose, Insulin, HOMA Index, HbA1c, Triglyceride (TG), Gesamt-, low- und highdensity Cholesterin (Chol, LDL; HDL) sowie hoch sensitives Creaktives Protein (hsCrP). Mittels multivariater linearer Regressionsanalysen wurde geprüft, inwieweit die einzelnen Indizes der kardiorespiratorischen Fitness unabhängig von der Grösse und dem Gewicht der Personen mit den metabolischen Risikofaktoren assoziiert sind.

Resultate: Bei den Frauen erklärte Watt-peak 1,4 bis 2,8\% der Varianz der Glukose- und $\mathrm{HbA} 1 \mathrm{c}$-Werte, während $\mathrm{VO}_{2}$-peak $1,5 \%$ der Varianz der hsCrP-Werte erklärte (alle beta $<-0,13$; alle $p<0,05$ ). Bei den Männern erklärte Watt-peak 3,6 bis $11,8 \%$ der Varianz der Glukose-, Insulin-, HOMA-, HbA1c- sowie TG-Werte (alle beta $<-0,20$; alle $\mathrm{p}<0,03$ ). Watt-AT war ein unabhängiger Prädiktor der Insulin-, HOMA-, TG-, Chol-, und LDL-Werte und erklärte 3,9-11,6\% der jeweiligen Varianz (alle beta $<-0,19$; alle $\mathrm{p}<0,04$ ). $\mathrm{VO}_{2}$-peak konnte $5,4 \%$ der Varianz der TG-Werte erklären, während $\mathrm{VO}_{2}$-AT eine unabhängige Determinante 
der TG-, Chol- und LDL-Werte sowie des Chol/HDL-Ratio darstellte $\left(\mathrm{R}^{2}=4,0-7,7 \%\right.$; alle beta $<-0,19$; alle $\left.\mathrm{p}<0,05\right)$.

Schlussfolgerung: Unsere Daten zeigen, dass auch bei Personen mit ausgeprägter Adipositas eine erhöhte kardiorespiratorische Fitness mit einem günstigeren kardiometabolischen Risikoprofil assoziiert ist. Be Männern scheint dieser Zusammenhang stärker ausgeprägt zu sein als bei Frauen.

\section{P92}

\section{ASSOZIATION ZWISCHEN ANTHROPOMETRISCHEN INDIZES DER ABDOMINALEN ADIPOSITAS UND METABOLISCHEN RISIKOFAKTOREN BEI PERSONEN MIT SEHR AUSGEPRÄGTER ADIPOSITAS}

\section{Zazai, R. ${ }^{1}$; Wilms, B. ${ }^{1}$; Ernst, B. ${ }^{1}$; Schultes, B. ${ }^{1}$}

${ }^{1}$ Interdisziplinäres Adipositas Zentrum, Kantonsspital St. Gallen, Rorschach, Schweiz

Einleitung: Eine Vielzahl von Studien belegt, dass ein erhöhter Taillenumfang (TU) mit einem gesteigerten metabolischen Risiko einhergeht Neben dem TU wurden weitere anthropometrische Indizes der abdominalen Adipositas entwickelt, die im Vergleich zum TU eine bessere Prädiktion hinsichtlich des Mortalitäts- und Morbiditätsrisiko liefern sollen. Unklar ist, ob der TU auch bei sehr ausgeprägter Adipositas eine unabhängige Assoziation zu metabolischen Risikofaktoren zeigt und welchen Stellenwert diesbezüglich die neuen Indizes besitzen.

Methode: In die Querschnittsstudie wurden 567 adipöse Frauen (BMI: $44,4 \pm 6,0 \mathrm{~kg} / \mathrm{m}^{2}$, Alter: 41,3.5 $\pm 12,2 \mathrm{Jahre}$ ) und 271 Männer (BMI

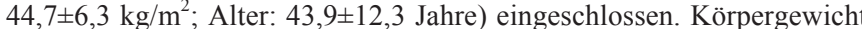
und -größe sowie Taillen- und Hüftumfang wurden bestimmt und folgende Indizes berechnet: BMI, Waist/Hip-, Waist/HeightWaist/Height ${ }^{2}$-, Waist $/$ Height $^{3}$ - und Height $^{3} /$ Waist ${ }^{3}$-Ratio. Mittels schrittweiser, multipler linearer Regressionsanalysen wurde geprüft, inwieweit die einzelnen Indizes bei gleichzeitiger Berücksichtigung von Größe und Gewicht bzw. BMI die Varianz metabolischer Risikofaktoren erklären. Folgende Risikofaktoren wurden betrachtet: Glukose, Insulin, HOMA, HbA1c, Triglyzeride, Gesamt-, low-, high-densitiy Lipoprotein (Chol, LDL, HDL, Chol/HDL-Ratio), C-reaktives Protein (hsCrP), Blutdruck.

Ergebnis: Bei den Frauen erklärten Waist/Height sowie Waist/Height ${ }^{3}$ 2,0 bis $3,1 \%$ der Varianz der HbA1c-, Insulin-, HOMA- und Triglyzerid-Werte (alle $\mathrm{p}<0,008$ ), während TU- und Hüftumfang sowie Waist/Height 0,9 bis 3,4\% der Varianz der Glukose-, HDL-, Chol/HDLund Blutdruck-Werte erklärten (alle $p<0,001$ ). Bei Männern war der TU der stärkste unabhängige Prädiktor für die HbAlc-, Insulin-, HOMAund Blutdruck-Werte, während Waist/Height die Varianz der HDLWerte mit erklärte (alle $\mathrm{R}^{2}=2,5-11,9 \%$; alle $\mathrm{p}<0,001$ ). Einzig Waist/Height ${ }^{2}$ konnte Varianz der hsCrP-Werte erklären $\left(\mathrm{R}^{2}=11,6 \%\right.$; $\mathrm{p}<0,001)$. Interessanterweise war keiner der Indizes Prädiktor der Cholund LDL-Werte bei Frauen und Männern (alle p>0,112).

Zusammenfassung: Unsere Daten belegen, dass die Messung des TUs bei Patienten mit sehr ausgeprägter Adipositas von klinischer Relevanz ist, da dieser unabhängig von Grösse und Gewicht bzw. BMI mit metabolischen Risikofaktoren assoziiert ist. Die getesteten neuen Indizes lieferten hingegen keine deutlich besseren Assoziationen zum metabolischen Risiko im Vergleich zum TU.
P93

\section{TCF7L2 AND FTO - WHAT CAN WE LEARN FROM METABOLIC CHALLENGE TESTS?}

Wahl, S. ${ }^{1}$; Then, C. ${ }^{2}$; Krug, S. ${ }^{3}$; Brand, T. ${ }^{3}$; Ehlers, $K^{3}$,

Claussnitzer, M. ${ }^{3}$; Skurk, T. ${ }^{3}$; Lechner, A. ${ }^{2}$; Wichmann, H.-E. ${ }^{4}$; Heier, M. ${ }^{5}$; Huth, C. ${ }^{5}$; Thorand, B. ${ }^{5}$; Meisinger, C. ; Prehn, C. ${ }^{5}$; Stückler, F. ${ }^{7}$; Kastenmüller, G. ${ }^{7}$; Adamski, J. ${ }^{6}$; Suhre, K. ${ }^{7}$; Illig, T. ${ }^{1}$; Grallert, H. $^{1}$; Laumen, H. $^{3}$; Hauner, H. $^{3}$; Seissler, J. ${ }^{2}$

${ }^{1}$ Research Unit of Molecular Epidemiology, Helmholtz Zentrum München, Neuherberg, Germany; ${ }^{2}$ Diabetes Center, Medical Clinic Innenstadt, Ludwig Maximilians University, Munich, Germany; ${ }^{3}$ EKFZ, Technical University München, Freising-Weihenstephan, Germany; ${ }^{4}$ Institute of Epidemiology I, Helmholtz Zentrum München, Neuherberg, Germany; ${ }^{5}$ Institute of Epidemiology II, Helmholtz Zentrum München, Neuherberg, Germany; ${ }^{6}$ Institute of Experimental Genetics, Helmholtz Zentrum München, Neuherberg, Germany; ${ }^{7}$ Institute of Bioinformatics and Systems Biology, Helmholtz Zentrum München, Neuherberg, Germany

Objective: Common genetic variants in the FTO and TCF7L2 gene loci have been consistently associated with obesity and type 2 diabetes mellitus, respectively. The mechanisms underlying these associations remain poorly understood. Here, we focused on the functional characterization of the variants rs9939609 (FTO) and rs7903146 (TCF7L2). We present an approach comprising measurement of plasma metabolite concentrations during intravenous challenge tests to investigate early metabolic alterations in healthy risk allele carriers.

Methods: 78 healthy male participants of the KORA S4/F4 cohort, aged 34 to 67 years, were recruited. They comprised 24 homozygous carriers of the FTO locus risk allele rs9939609, 17 carriers of the TCF7L2 locus risk allele rs7903146 and 24 non-carriers of both alleles as control subjects. Subjects undertook an intravenous glucose tolerance test (ivGTT) in the fasting state, followed by a euglycemic hyperinsulinemic clamp test. During the intervention, blood was sampled for biochemical and metabolomics measurement. Plasma samples were analyzed using a mass spectrometry-based metabolomics approach targeting 163 metabolites (AbsoluteIDQTM p150 kit, Biocrates Life Sciences AG).

Results: Challenges induced marked metabolic changes independent of genotype.

FTO risk allele carriers did not differ from control subjects in their metabolic challenge response. However, we observed significant differences in the ivGTT response comparing TCF7L2 risk allele carriers and control subjects, including a reduced first-phase insulin secretion and a stronger decline of a range of sphingomyelin and lysophosphatidylcholine metabolites in the carriers.

Conclusion: Our study confirms a role of TCF7L2 in insulin secretion. Furthermore, a connection of TCF7L2 to phospholipid metabolism was shown. The presented design provides a framework for further analysis of additional risk variants.

\section{PIE ENERGIEDICHTE VON LEBENSMITTELN IN DEUTSCHLAND KORRELIERT MIT EINEM NIEDRIGEN PREIS: HOCHKALORISCHE LEBENSMITTEL SIND BILLIGER}

Westenhöfer, J. ${ }^{1}$

${ }^{1}$ Hochschule für Angewandte Wissenschaften Hamburg, Fakultät Life Sciences, Hamburg, Deutschland

Fragestellung: Es ist gut belegt, dass ein niedriger sozio-ökonomischer Status mit einer höheren Prävalenz der Adipositas einhergeht. Allerdings ist weit weniger klar, warum das der Fall ist. Es wurde die Hypothese vorgebracht (Drewnowski u.a. 2004, 2005), dass eine Erklärung darin liegen kann, dass Lebensmittel mit hoher Energiedichte (kcal/100 g) relativ gesehen (Preis pro kcal) billiger sind als Lebensmittel mit geringer Energiedichte. Daher könnte ein geringes verfügbares Einkommen dazu beitragen, dass bevorzugt Lebensmittel mit hoher Energiedichte konsumiert werden, da so der Energiebedarf mit relativ wenig Geld befriedigt werden kann. Daten über Lebensmittelpreise und Energiedichte stützen diese Hypothese in verschiedenen Ländern, u.a. USA 
und Frankreich. Für Deutschland sind hierzu keine systematischen Daten bekannt.

Methode: Durch Begehung von Supermärkten und Geschäften des Lebensmitteleinzelhandels wurde die Preise und Packungsgrößen von insgesamt 603 Lebensmitteln aus 9 verschiedenen Lebensmittelgruppen (Obst, Gemüse, Nudeln-Reis-Brot, Fleisch, Fleisch- und Wurstwaren, Milch und Milchprodukte, Fette, Süßigkeiten und Snacks, Fertiggerichte) erhoben. Der Energiegehalt wurde ebenfalls - soweit angegeben von den Packungen übernommen oder einschlägigen Nährwertdatenbanken eruiert. Die Energiedichte wurde wurde als kcal pro $100 \mathrm{~g}$, der relative, energiebezogene Preis wurde als Euro pro $100 \mathrm{kcal}$ berechnet und für die Analyse der Zusammenhänge logarithmisch transformiert.

Ergebnisse: Über alle Lebensmittelgruppen hinweg, korrelierte der logtransformierte energiebezogene Preis negativ mit der Energiedichte $(\mathrm{r}=$ $-0,59, \mathrm{p}<0,001)$. Auch innerhalb der meisten Lebensmittelgruppen ergab sich eine signifikante negative Korrelation. Lediglich innerhalb der Gruppen Obst, Milch und Milchprodukte sowie Süßigkeiten und Snacks war die Korrelation nicht signifikant.

Schlussfolgerungen: Auch in Deutschland sind Lebensmittel mit hoher Energiedichte relativ billig, liefern also viele Kalorien pro Euro. Unter ökonomischen Gesichtspunkten ist es daher wahrscheinlich, dass diese Lebensmittel bei geringem Einkommen bevorzugt konsumiert werden und so auf Grund ihrer Energiedichte eine erhöhte Nahrungsaufnahme begünstigen.

\section{P95}

\section{SAGITTAL-DIAMETER: EIN BESSERER PRÄDIKTOR FÜR METABOLISCHE RISIKOFAKTOREN ALS DER TAILLENUMFANG BEI ADIPOSITAS?}

\section{Zazai, R. ${ }^{1}$; Waldburger, R. $^{1}$; Wilms, B. ${ }^{1}$; Ernst, B. ${ }^{1}$; Schultes, $B .{ }^{1}$} ${ }^{1}$ Interdisziplinäres Adipositas Zentrum, Kantonsspital St. Gallen, Rorschach, Schweiz

Einleitung: Eine Vielzahl von Studien belegt, dass ein erhöhter Taillenumfang (TU) mit einem gesteigerten metabolischen Risiko einhergeht. Alternativ zum TU kann das Ausmaß der abdominellen Fettmasse mittels des Sagittaldiameters (SD) bestimmt werden, welcher im Vergleich zum Taillenumfang eine bessere Prädiktion hinsichtlich des Mortalitäts- und Morbiditätsrisiko liefern soll. Ziel der Studie war ein Vergleich von TU und SD als Determinanten des metabolischen Risikos bei Frauen und Männern mit Adipositas.

Methode: Bei 204 adipösen Frauen (BMI: 41,5 $\pm 6,5 \mathrm{~kg} / \mathrm{m} 2$, Alter

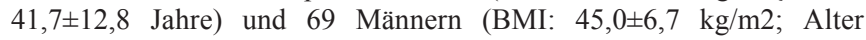
$46,2 \pm 12,8$ Jahre) wurde neben Körperwicht und -grösse, das abdominelle Fett mittels TU und SD bestimmt. Mittels multipler, schrittweiser multivariater Regressionsanalysen wurde geprüft, inwieweit SD und TU unabhängig von Alter, Grösse und Gewicht die Varianz metabolischer Risikofaktoren mit erklären können. Folgende Risikomarker wurden betrachtet: Glukose, Insulin, HOMA Index, HbA1c, Triglyzeride (TG), Gesamt-, low- and high-density Cholesterin (Chol, LDL; HDL, LDL/HDL-Ratio), C-reaktives Protein (hsCrP) und Blutdruck.

Ergebnis: Bei Frauen erklärte SD 5,4\% $(\mathrm{p}<0,001)$ der Varianz (R2) der Glukose-Werte, TU weitere $2,5 \%(\mathrm{p}=0,023)$. Die Varianz im Insulin wurde durch SD mit $2,8 \%(p=0,023)$ sowie das Gewicht $(\mathrm{R} 2=18,3 \%$; $\mathrm{p}=0,003)$ erklärt. TU war alleiniger Prädiktor der HOMA-Werte ( R2 $=14,9 \%)$ und zusätzlich zum Alter ( $2=8,3 \%)$ Prädiktor des HbA1c ( $R 2=11,4 \%$; alle $\mathrm{p}<0,001)$. Bei den Männern war SD alleiniger Prädiktor der Glukose-Werte $(\mathrm{R} 2=8,4 \% ; \mathrm{p}=0,034)$. Varianzen in Insulin und HOMA konnten nicht erklärt werden. Bei den Frauen erklärte einzig SD $5,4 \%$ der Varianz in Chol $(\mathrm{p}=0,001)$, während die der TG durch TU $(\mathrm{R} 2=4,8 \% ; \mathrm{p}=0,001)$ sowie Gewicht $(\mathrm{R} 2=4,0 \% ; \mathrm{p}=0,001)$ und $\mathrm{SD}$ ( $\mathrm{R} 2=3,7 \% ; \mathrm{p}=0,011)$ erklärt wurden. TU war einziger Prädiktor des LDL/HDL-Ratio ( $\mathrm{R} 2=3,1 \%$; $\mathrm{p}=0,028)$, sowie mit Grösse ( $\mathrm{R} 2=7,3 \%)$ des HDL ( $22=4,8 \%$; beide $\mathrm{p}=0,004)$. Stärkster Prädiktor des hsCrP war die Grösse ( $2=4,6 \% ; p<0,001)$ und zusätzlich das Gewicht ( $R 2=4,3 \%$; $\mathrm{p}=0,005)$. Bei Männern waren bzgl. der Lipide weder SD noch TU signifikante Prädiktoren. Varianzen im Blutdruck konnten weder durch TU noch SD in beiden Geschlechtern erklärt werden.

Zusammenfassung: Unsere Daten zeigen, dass sowohl TU als auch SD wichtige Parameter zur Vorhersage des metabolischen Risikos sind. Es gibt jedoch erste Hinweise, dass das SD bei adipösen Frauen bessere Aussagen zum metabolischen Risiko liefert.

\section{P96 \\ OBESITY AND ASSOCIATED LIFESTYLE IN A LARGE SAMPLE OF MULTI-MORBID GERMAN PRIMARY CARE ATTENDEES}

Sikorski, C. ${ }^{1}$; Luppa, M. ${ }^{1}$; König, H.-H. ${ }^{2}$; Wiese, . $^{3}$; van den Bussche, H. $^{4}$; Scherer, M. ${ }^{4}$; Riedel-Heller, S.G. ${ }^{1}$

${ }^{1}$ Institut für Sozialmedizin, Arbeitsmedizin und Public Health, Universität Leipzig, Leipzig, Germany; ${ }^{2}$ Institut für Medizinische Soziologie,

Sozialmedizin und Gesundheitsökonomie (IMSG), Universitätsklinikum Hamburg-Eppendorf, Hamburg, Deutschland; ${ }^{3}$ Institut für Biometrie, Medizinische Hochschule Hannover, Hannover, Deutschland ${ }^{4}$ Institut für Allgemeinmedizin, Universitätsklinikum Hamburg-Eppendorf, Hamburg, Deutschland

Background: Obesity and the accompanying increased morbidity and mortality risk is highly prevalent among older adults. As obese elderly might benefit from intentional weight reduction, it is necessary to determine associated and potentially modifiable factors on senior obesity. This study focuses on multi-morbid patients which make up the majority in primary care.

Methods: A total of 3189 non-demented, multi-morbid participants aged 65-85 years were recruited in primary care within the German MultiCare-study in 2008 to 2009. A healthy lifestyle score (HLS) was introduced. BMI (e.g. general obesity) and waist circumference (WC, abdominal obesity) were used as outcome measures.

Results: About one third of all patients were classified as obese according to BMI. The prevalence of abdominal obesity was $75 \%$. Adjusted for sociodemographic variables and disease burden, participants with the highest HLS displayed a lower BMI $\left(-0.7 \mathrm{~kg} / \mathrm{m}^{2}, \mathrm{p}<0.016\right)$ and WC $(-4.3 \mathrm{~cm}, \mathrm{p}<0.001)$. Additionally, in multivariate regression, higher subjective and objective health-related impairment were associated with lower WC and BMI. For individual lifestyle choices, higher physical activity $(\beta=1.111 ; \mathrm{p}<.01)$ and current smoking $(\beta=-1.543 ; \mathrm{p}<.01)$ were associated with BMI.

Conclusion: Assessment of $\mathrm{WC}$ as a measure of obesity in multimorbid elderly seems inevitable in order to identify individuals at risk. Yet, age-specific thresholds for the BMI are needed likewise. The general practitioner plays an essential role in delivering weight counseling to older patients and is able to assess relevant lifestyle choices. Encouraging and promoting physical activity in older adults might a starting point for weight reduction efforts.

\section{P97}

\section{SCHWANGERSCHAFT NACH BARIATRISCHEN EINGRIFFEN}

Tanay, E. ${ }^{1}$; Müller, M.W. ${ }^{2}$; Raggi, M.C. ${ }^{1}$

${ }^{1}$ Klinikum Stuttgart, Krankenhaus Bad Cannstatt, Adipositaszentrum, Stuttgart, Deutschland; ${ }^{2}$ Klinikum Stuttgart, Krankenhaus Bad Cannstatt, Chirurgische Klinik, Stuttgart, Deutschland

Fragestellung: Etwa die Hälfte aller Patienten mit einem bariatrischen Eingriff sind Frauen im gebärfähigen Alter (18-45). Die starke Gewichtsabnahme durch Restriktion und Malabsorption nach bariatrischen Eingriffen, vor allem in den ersten Monaten des schnellsten Gewichtsverlustes, führte zu der Empfehlung der aktuellen S3-Leitlinie der DGAV (CA-ADIP), dass Patientinnen in den ersten 18 Monaten nicht schwanger werden sollten. Retrospektive Cohorten-Studien zeigen insgesamt eine Abnahme von Risikofaktoren wie Schwangerschaftsdiabetes, Präeklampsie, Eklampsie und Bluthochdruck.

Methodik / Ergebnisse: Es wurden gezielt Schwangerschaften im ersten Jahr nach bariatrischen Eingriffen unserer Klinik in den Jahren 2009-2011 untersucht

Fall I: Die 36jährige Patientin erhielt im September 2009 eine laparoskopische Sleeve-Resektion bei Adipositas Grad III mit einem BMI von $58 \mathrm{~kg} / \mathrm{m}^{2}$. Sie wurde entgegen unseren Empfehlungen ungewollt vier Monate postoperativ schwanger und hat im Oktober 2010 einen reifge- 
borenen Sohn durch Sectio in der 37+2 Schwangerschaftswoche entbunden. Die Sectio wurde der Mutter aufgrund eines Narbenbruches empfohlen. Geburtsgewicht des Kindes waren 3340 g, Geburts-Größe $53 \mathrm{~cm}$. Die Patientin hatte regelmäßige dreimonatliche Vitamin B12 i.m.-Gaben, Multivitamin- und Eiweißsupplementierung. Folsäure wurde zusätzlich nach Bekanntwerden der Schwangerschaft supplementiert. Das Kind ist gesund, die Schwangerschaft war komplikationslos.

Fall II: Die 31jährige Patientin erhielt bereits 2005 ein laparoskopisches Gastric Banding, dessen Lage bei einem Slippage 2009 korrigiert werden musste. Wegen erneutem Slippage wurde im März 2011 das Magenband entfernt und eine laparoskopische Sleeve-Resektion bei einem aktuellen BMI von $38 \mathrm{~kg} / \mathrm{m}^{2}$ durchgeführt. Diese Patientin wurde ebenfalls bereits sieben Monate postoperativ schwanger und hat ihre frühgeborene Tochter in der 36+1 Schwangerschaftswoche durch eine NotSectio entbunden, da das Kind bradykard wurde. Das Kind hat eine Trisomie 21, das Geburtsgewicht war $2780 \mathrm{~g}$ und eine Geburts-Größe von $47 \mathrm{~cm}$. Der Schwangerschaftsverlauf war kompliziert durch Schwangerschaftsdiabetes, der im siebten Monat festgestellt wurde. Auf dessen Boden entwickelte sich eine Herzmuskelhypertrophie des Kindes. Die Patientin supplementierte Vitamine direkt postoperativ und nach positivem Schwangerschaftstest zusätzlich Folsäure.

Schlussfolgerung / Diskussion:

Schwangerschaften nach bariatrischen Operationen müssen besser evaluiert werden um Patientinnen im gebärfähigen Alter vor, während und nach der Schwangerschaft besser beraten und behandeln zu können. Hierfür sollte die Datenerhebung im nationalen Adipositasregister erweitert werden. Insbesondere müssen Komplikationen in der Schwangerschaft und der Gesundheitszustand des Kindes erfasst werden. 